\title{
INVENTARISASI DAN KARAKTERISASI MORFOLOGI \\ TANAMAN SIJONTIAK (Baccaureapolyneura) \\ DI KECAMATAN GUGUAK, KABUPATEN LIMA PULUH KOTA
}

Oleh:

RANGGI RAHIMUL INSAN

0810212079

\author{
SKRIPSI \\ Sebagai Salah Satu Syarat \\ Untuk Memperoleh Gelar \\ Sarjana Pertanian
}

PROGRAM STUDI AGROEKOTEKNOLOGI

FAKULTAS PERTANIAN

UNIVERSITAS ANDALAS

PADANG

2012 


\section{INVENTARISASI DAN KARAKTERISASI MORFOLOGI \\ TANAMAN SIJONTIAK (Baccaureapolyneura) \\ DI KECAMATAN GUGUAK, KABUPATEN LIMA PULUH KOTA}

Oleh:

RANGGI RAHIMUL INSAN

0810212079

MENYETUJUI :

DosenPembimbing I

DosenPembimbing II

Dr. Ir. Benni Satria, MP

NIP. 196509301995121001

DekanFakultasPertanian

UniversitasAndalas

Prof. Ir. Ardi, MSc NIP. 195312161980031004
Prof. Ir. Ardi, MSc

NIP. 195312161980031004

Ketua Prodi Agroekoteknologi

FakultasPertanian

UniversitasAndalas

Dr. Jumsu Trisno, SP, MSi

NIP. 19691121199512100 
Skripsi ini telah diuji dan dipertahankan di depan Sidang Panitia Ujian Sarjana Fakultas Pertanian Universitas Andalas, pada tanggal 31 Oktober 2012.

\begin{tabular}{|l|l|l|l|}
\hline No. & \multicolumn{1}{|c|}{ Nama } & TandaTangan & \multicolumn{1}{|c|}{ Jabatan } \\
\hline 1 & Dr. PK. Dewi Hayati, SP, MSi & & Ketua \\
3 & Dini Hervani, SP, MSi & Sekretaris \\
4 & Dra. Netti Herawati, MSc & & Anggota \\
& Dr. Aprizal Zainal, SP, MSi & & Anggota \\
\hline 5 & Dr. Ir. Benni Satria, MP & & \\
\hline
\end{tabular}




\section{KATA PENGANTAR}

Puji dan syukur penulis ucapkan kehadirat Allah SWT yang telah memberikan rahmat dan karunia-Nya sehingga penulis dapat menyelesaikan penulisan skripsi penelitian yang berjudul "Inventarisasi dan Karakterisasi Morfologi Tanaman Sijontiak (Baccaurea polyneura) di Kecamatan Guguak Kabupaten Lima Puluh Kota."

Penulis mengucapkan terima kasih dan penghargaan yang sebesar besarnya kepada Bapak Dr. Ir. Beni Satria, MP dan Bapak Prof. Ir. Ardi, M.Sc selaku dosen pembimbing yang telah banyak memberikan saran, arahan terutama bimbingan dan dorongan semangat dalam menyelesaikan penulisan skripsi ini. Ucapan terima kasih juga penulis sampaikan kepada Ketua Jurusan dan Sekretaris, Staf Pengajar, Karyawan dan karyawati di lingkungan Fakultas Pertanian Universitas Andalas serta Bapak Refredi (penunjuk arah lokasi tanaman sijontiak di lapangan) dan ibu Nurwanita Eka Sari Putri, SP, Msi serta Ibu Dini Hervani, SP, Msi, juga peran serta rekan-rekan mahasiswa/i dan semua pihak yang telah ikut membantu baik secara langsung maupun tidak langsung dalam proses penulisan skripsi ini.

Tidak lupa juga kepada Bapak Bupati Kabupaten Lima Puluh Kota, Bapak Camat Guguak beserta bawahan, dan Wali Jorong se Kecamatan guguak beserta staf atas kesediaan membantu proses kelancaran dari pelaksanaan penelitian skripsi ini.

Harapan penulis semoga skripsi ini dapat bermanfaat dalam upaya pelestarian plasma nutfah dan dapat memberikan kontribusi dalam perkembangan ilmu pengetahuan khususnya dibidang pertanian. Amin. 


\section{DAFTAR ISI}

\begin{tabular}{|c|c|}
\hline \multirow{2}{*}{ KATA PENGANTAR } & Halaman \\
\hline & iv \\
\hline DAFTAR ISI & $\mathbf{v}$ \\
\hline DAFTAR TABEL & vi \\
\hline 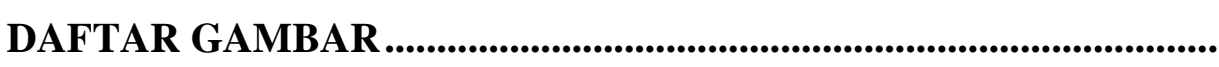 & vii \\
\hline DAFTAR LAMPIRAN & \\
\hline
\end{tabular}

I. PENDAHULUAN

1.1 Latar Belakang ............................................................................................. 1

1.2 Tujuan .................................................................................. 3

II. TINJAUAN PUSTAKA

2.1 Botani Sijontiak .............................................................................................. 5

2.2 Manfaat Genus Baccaurea ............................................................ 5

2.3 Syarat Tumbuh Genus Baccaurea.................................... 6

2.4 Botani Tanaman Sijontiak......................................... 6

2.5 Pentingnya Keragaman Plasma Nutfah............................. 7

\section{BAHAN DAN METODA}

3.1 Waktu dan Tempat .................................................................... 10

3.2 Bahan dan Alat .......................................................................... 10

3.3 Metode Penelitian ............................................................................... 10

3.4 Pelaksanaan Penelitian ............................................................... 10

3.5 Pengamatan ............................................................................................. 11

3.6 Analisis Kemiripan ................................................................... 18

3.7 Analisis Data Fenotipik .................................................................. 18

\section{HASIL DAN PEMBAHASAN}

4.1 Profil Kabupaten Lima Puluh Kota ................................................... 20

4.2 Penampilan morfologi .................................................................... 22

4.3 Analisis Kadar Gula Sijontiak ........................................................ 31

4.4 Hasil pengisian kuisioner dan wawancara dengan petani sijontiak .. 32

4.5 Analisis Kemiripan .......................................................................... 33

4.6 Variabilitas Fenotipik .................................................................. 39

V. KESIMPULAN DAN SARAN

5.1 Kesimpulan ................................................................................ 43

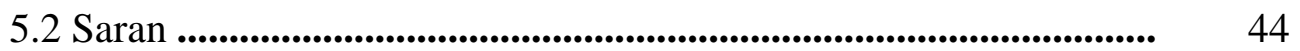

DAFTAR PUSTAKA 45

$\begin{array}{ll}\text { LAMPIRAN } & 48\end{array}$ 


\section{DAFTAR TABEL}

$\underline{\text { Tabel }}$

$\underline{\text { Halaman }}$

1. Rincian jumlah aksesi per kecamatan .................................... 21

2. Data Fenotipik Tanaman Sijontiak ........................................ 40 


\section{DAFTAR GAMBAR}

Gambar

$\underline{\text { Halaman }}$

1. Metode Pengukuran Tinggi Tanaman........................... 12

2. Bentuk tajuk tanaman sijontiak .................................... 23

3. Tipe batang tanaman sijontiak ...................................... 24

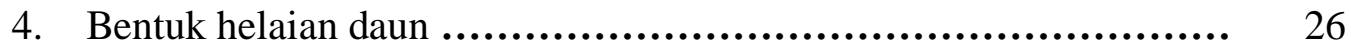

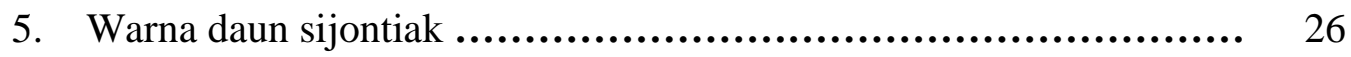

6. Morfologi bentuk buah sijontiak ................................... 28

7. warna daging buah sijontiak ...................................... 29

8. Penampilan warna kulit buah sijontiak .............................. 29

9. Bentuk biji sijontiak ............................................ 30

10. Morfologi bunga sijontiak ....................................... 31

11. Dendogram tanaman sijontiak Kabupaten Lima Puluh Kota ........... 34

12. Dendogram kualitatif tanaman sijontiak Kabupaten Lima Puluh Kota ......................................... 37

13. Dendogram kuantitatif tanaman sijontiak Kabupaten Lima Puluh Kota ...................................... 38 


\section{DAFTAR LAMPIRAN}

$\underline{\text { Halaman }}$

1. Jadwal Kegiatan Penelitian dari Bulan Maret - Juni 2012 ............. 48

2. List Deskriptor Acuan variabel Pengamatan Morfologi sijontiak....... 49

3. Daftar Pertanyaan (Kuisioner) ................................ 57

4. Peta Kabupaten Lima Puluh kota ................................ 59

5. Peta Kecamatan Guguak ......................................... 60

6. Nama-Nama Kecamatan dan Nagari di Kabupaten Lima Puluh Kota 60 ................................................ 61

7. Posisi geografis masing-masing tanaman sijontiak yang diamati di Kabupaten Lima Puluh Kota ........................................ 62

8. Data morfologis tanaman sijontiak yang diamati di Kabupaten Lima Puluh Kota

9. Data morfologis batang tanaman sijontiak yang diamati di Kabupaten Lima Puluh Kota...

10. Data morfologis daun tanaman sijontiak yang diamati di KabupatenLima Puluh Kota

11. Data morfologis buah tanaman sijontiak yang diamati di Kabupaten Lima Puluh Kota

12. Data morfologis biji tanaman sijontiak yang diamati di Kabupaten Lima Puluh Kota

13. Hasil data kuisioner dari pemilik tanaman sijontiak 88

14. Data Hasil Analisa Kadar Gula 95

15. Keterangan mengenai kode aksesi tanaman sijontiak 96

16. Deskripsi 63 aksesi tanaman sijontiak yang diamati di Kabupaten Lima Puluh Kota 


\title{
INVENTARISASI DAN KARAKTERISASI MORFOLOGI \\ TANAMAN SIJONTIAK (BaccaureaPolyneura) \\ DI KECAMATAN GUGUAK, KABUPATEN LIMA PULUH KOTA
}

\begin{abstract}
ABSTRAK
Penelitian inventarisasi dan karakterisasi morfologis tanaman sijontiak (Baccaurea polyneura) telah dilaksanakan pada Kecamatan Guguak, Kabupaten Lima Puluh Kota. Penelitian ini dilakukan pada Bulan Maret-Juni 2012 yang bertujuan untuk mendapatkan informasi awal tentang karakter morfologi, tingkat kemiripan morfologi, dan mengetahui variabilitas fenotipik dari aksesi sijontiak. Metode yang digunakan adalah metode survei, dengan pengambilan sampel secara sengaja (Purposive Sampling) yaitu sampel diambil berdasarkan unsur-unsur yang dikehendaki dengan menetapkan Kecamatan Guguak, Kabupaten Lima Puluh Kota sebagai lokasi penelitian. Kriteria tanaman yang diamati adalah yang sudah pernah berbuah baik yang dibudidayakan maupun yang tidak dibudidayakan. Pengambilan data berupa data primer dan skunder, untuk melihat tingkat kemiripan antar tanaman sijontiak dilakukan analisis kemiripan dengan program NTSYS $_{\mathrm{pc}}$ versi 2.02i. Hasil penelitian di Kecamatan Guguak, Kabupaten Lima Puluh Kota ditemukan 63 aksesi sijontiak dengan bentuk tajuk, batang, buah, dan biji yang berbeda tiap aksesi. Berdasarkan analisis kemiripan pada dendogram dengan menggunakan data kualitatif dan data kuantitatif menunjukan adanya hubungan kemiripan 63 aksesi tanaman sijontiak sebesar 29\%. Data kualitatif menunjukan kemiripan sebesar $31 \%$ sedangkan untuk data kuantitatif menunjukan kemiripan sebesar 26\%. Dari pengamatan menunjukan bahwa tanaman sijontiak memiliki variabilitas fenotipik secara umum luas.
\end{abstract}

Kata kunci : inventarisasi, karakterisasi, morfologi, tanaman sijontiak, dan plasma nutfah 


\title{
INVENTORY AND MORPHOLOGICAL CHARACTERISTICS SIJONTIAK (Baccaurea Polyneura) PLANTS IN GUGUAK SUBDISTRICK OF LIMA PULUH KOTA DISTRICT
}

\begin{abstract}
The research of inventory and morphological characteristics of sijontiak (Baccaurea polyneura) plants was conducted in guguak subdistrict of Lima Puluh Kota district. This research was conducted from March to June 2012, it's aimed to have some beginning information about morphological character, morphological similarity level, and knowing phenotypic variability of sijontiak. The method which was used in this research based on survey method by taking samples intentionally (Purposive sampling). The samples were taken based on intended elements by deciding Guguak Subdistrict in Lima Puluh Kota District as a research location the criteria of the plant which was observed that had been fruited both cultivated and non cultivated. Data finding were primary and secondary data. To observe the degree of similarity among sijontiak plants had been done similarity analysis with NTSYS $S_{\mathrm{pc}}$ program version 2.02i. the result of the research in Guguak Subdistrict of Lima Puluh Kota District was found 63 variety of sijontiak which had various shapes, enown, stalk, fruit, and seed those had different variety each other. Based on the similarity analyses at dendogram which used qualitative and quantitative data showed there was relationship the similarity of 63 variety of sijontiak around $29 \%$. Qualitative data showed the similarities around $31 \%$ while quantitative data showed the similarites around $26 \%$. From the observation showed that sijontiak plants have generally large phenotypic variability.
\end{abstract}

Keywords: inventory, characteristics, morphology, plants sijontiak, and germ plasm 


\section{PENDAHULUAN}

\subsection{Latar Belakang}

Keanekaragaman jenis buah-buahan di Indonesia tergolong tinggi, namun buah-buahan yang berasal dari wilayah subtropik sangat diminati oleh konsumen di pasar domestik. Pasar lokal didominasi oleh buah-buahan yang berasal dari Cina, Thailand, dan Australia, sedangkan buah-buahan tropik asal negeri sendiri tidak disukai di pasar lokal, hal ini seharusnya menjadi pemikiran bagi siapa saja yang peduli pada tanaman hortikultura di Indonesia.

Keanekaragaman jenis dan plasma nutfah buah-buahan asli Indonesia sangat penting diperhatikan terutama sebagai modal dasar untuk pemuliaan tanaman pada buah-buahan. Inventarisasi jenis buah-buahan asli Indonesia perlu dilakukan agar dapat dimanfaatkan terutama dalam usaha meningkatkan kualitas dan kuantitas buah-buahan asli Indonesia sehingga dapat bersaing di pasar domestik maupun internasional dan dapat meningkatkan usaha penganekaragaman jenis buah-buahan yang dikonsumsi di Indonesia (LIPI, 2007).

Indonesia merupakan salah satu pusat keragaman genetik tanaman buah tropika, salah satunya sijontiak (Baccaurea polyneura). Tanaman ini termasuk buah eksotik tropika yang mempunyai rasa buah manis dengan sedikit asam. Hal ini merupakan potensi lokal Kabupaten Lima Puluh Kota yang patut dikembangkan untuk pelestarian plasma nutfah, memenuhi kebutuhan masa datang dan agar mampu bersaing di pasaran dengan buah yang berasal dari wilayah subtropik. Tanaman ini belum dibudidayakan dengan baik, biasanya masih terdapat di rawa dan di sekitar pekarangan rumah masyarakat.

Perusakan habitat, penebangan pohon, kebakaran hutan maupun alih fungsi lahan menyebabkan keanekaragaman hayati plasma nutfah ini berangsurangsur berkurang baik dari segi kualitas, maupun dari segi kuantitasnya. Kondisi tersebut mengkhawatirkan karena akan kehilangan sumber plasma nutfah yang sangat merugikan, terutama bagi para pemulia yang ingin merakit varietas baru untuk peningkatan kualitas tanaman di kemudian hari.

Tanaman ini masih tumbuh liar dan hampir tidak ada kegiatan pemulian yang pernah dilakukan. Keadaan ini semakin mengkhawatirkan karena banyaknya 
jenis buah impor yang masuk ke Indonesia, menyebabkan beberapa buah lokal terancam keberadaanya termasuk sijontiak. Oleh karena itu, diperlukan sistem budidaya yang terpadu agar tanaman ini tidak punah dan bisa digunakan di dalam pelestarian plasma nutfah.

Sijontiak merupakan anggota dari genus Baccaurea yang membutuhkan ketersediaan air, ketinggian tempat, curah hujan serta suhu udara yang optimum. Ketinggian tempat yang diinginkan oleh tanaman ini berkisar antara 20-600 m dpl (Haegens,2000). Kabupaten Lima Puluh Kota beriklim tropis, dan memiliki ketinggian tempat 500-1025 m dpl (limapuluhkota.go.id). Perbandingan antara ketinggian tempat yang diinginkan dengan ketinggian tempat dari Kabupaten Lima Puluh Kota sangat potensial bagi pertumbuhan sijontiak.

Ketertarikan masyarakat lokal terhadap tanaman ini cukup tinggi karena mempunyai potensi sebagai buah komersial. Menurut Nazarudin dan Muchlisah (1994), buah komersial adalah buah yang sangat digemari dan mempunyai daya tarik tersendiri bagi konsumen. Tanaman ini memiliki bentuk daging buah berwarna terang dan kulit buah yang berongga sehingga mudah untuk dibuka. Setiap buah ini masak sering dijual di pasar-pasar yang berada di wilayah Kabupaten Lima Puluh Kota, Batusangkar, dan Bukitinggi.

Kecamatan Guguak yang berada di Kabupaten Lima Puluh Kota terdiri dari kanagarian Kubang, Guguak VIII Koto, VII Koto Talago, Sungai Tolang, dan Simpang Sugiran (BPS, 2009). Menurut masyarakat di wilayah ini, setiap nagari pada Kecamatan ini umumnya ditumbuhi oleh tanaman sijontiak dan merupakan kecamatan yang paling banyak ditumbuhi oleh tanaman sijontiak dibandingkan dengan kecamatan lain. Keanekaragaman tanaman ini masih belum diketahui karakteristiknya dan relatif tidak pernah dilakukan koleksi plasma nutfahnya pada Kecamatan ini, sebelum terjadi erosi genetiknya maka perlu dilakukan inventarisasi dan karakterisasi morfologisnya.

Poespodarsono (1988) menyebutkan, langkah yang harus dilakukan oleh seorang pemulia untuk memuliakan suatu tanaman adalah dengan menyediakan materi pemuliaan. Pemuliaan tanaman dapat dilakukan apabila terdapat perbedaan materi genetik yang dimiliki oleh tanaman. Jadi, untuk melakukan pemuliaan pada 
tanaman diperlukanlah keragaman. Keragaman tersebut dapat diketahui melalui inventarisasi dan karakterisasi.

Inventarisasi merupakan kegiatan turun ke lapangan mengumpulkan data tentang jenis-jenis tumbuhan yang ada di daerah tersebut. Kegiatan inventarisasi ini meliputi kegiatan eksplorasi dan identifikasi. Eksplorasi yaitu kegiatan yang bertujuan mengumpulkan dan mengkoleksi semua sumber keragaman genetik yang tersedia baik spesies liar, kultivar lokal, varietas unggul, varietas introduksi, dan lain-lain, sedangkan identifikasi merupakan suatu kegiatan karakterisasi semua sifat yang dimiliki atau yang terdapat pada sumber keragaman genetik sebagai data base sebelum memulai rencana pemuliaan tanaman. Karakterisasi merupakan kegiatan dalam rangka mengidentifikasi dan mengelompokan sifatsifat yang bernilai ekonomis, atau yang merupakan penciri dari varietas yang bersangkutan.

Inventarisasi dan karakteristik sijontiak sangat diperlukan sebagai parameter dalam perakitan varietas unggul dan juga sebagai pelestarian plasma nutfah, namun sampai saat ini data karakteristiknya belum tersedia. Adanya perhatian yang serius dari suatu badan atau instansi terkait diharapkan dapat mempertahankan tanaman ini dari keterkikisan dan kepunahan. Kegiatan inventarisasi dan karakterisasi terhadap morfologisnya diharapkan dapat mengungkapkan potensi unggulan dari tanaman ini dan informasi yang diperoleh dapat digunakan sebagai acuan untuk mengenal sijontiak yang ada di daerah ini dalam ruang lingkup yang lebih jelas.

Berdasarkan uraian di atas penulis telah melakukan penelitian dengan judul "Inventarisasi dan Karakterisasi Morfologi Tanaman Sijontiak (Baccaurea polyneura) Di Kecamatan Guguak, Kabupaten Lima Puluh Kota".

\subsection{Tujuan Penelitian}

Penelitian ini bertujuan untuk mendapatkan informasi awal tentang karakteristik morfologi, tingkat kemiripan morfologi dan mengetahui variabilitas fenotipik dari jenis-jenis sijontiak (Baccaurea polyneura) di Kecamatan Guguak, Kabupaten Lima Puluh Kota. Hasil yang diharapkan dari penelitian ini adalah diperolehnya informasi keragaman morfologi sijontiak dengan berbagai sifat 
sehingga nantinya dapat memberikan informasi bagi pemulia tanaman dan memperkaya informasi yang sudah ada sehingga akan lebih bermanfaat. 


\section{TINJAUAN PUSTAKA}

\subsection{Botani Genus Baccaurea}

Baccaurea adalah nama genus tumbuhan berbunga anggota dari phylanthaceae. Genus ini dikenal sebagai penghasil buah-buahan, dengan beberapa contoh jenis yang popular seperti Baccaurea dulcic (cupa), Baccaurea motleyana (Rambai), Baccaurea recemosa (menteng). Banyak pula anggota dari baccaurea yang menghasilkan kayu-kayuan, meskipun jarang yang berukuran besar menyebar di India, Asia Tenggara dan kawasan Indomalaya hingga pasifik, para ahli berbeda pendapat mengenai jumlah spesies marga baccaurea setepatnya (Haegens, 2000).

Genus ini umumnya berbentuk pohon yang tingginya sampai 30 meter. Kegunaan dari tumbuhan ini bervariasi diantaranya sebagai tanaman penghasil buah dan banguan, meskipun banyak juga yang belum tergali potensinya dan tumbuh liar dikawasan hutan. Jenis dari marga baccaurea dapat tumbuh pada kawasan di ketinggian 500-1000 m dpl. Pusat penyebaran paling banyak adalah di kawasan sumatera, Malaisya bagian barat, philipina, borneo, dan jawa (Heywood, 1978).

Genus ini umumnya memiliki daun berbentuk oval sampai bulat telur terbalik, tumpul, meruncing, panjang 7-20 cm, lebar 3-7,5 cm. tanaman berumah dua, dalam karangan bunga yang berbentuk tandan, berasal dari cabang yang tua. Bunga jantan kecil terkumpul pada anak tangkai yang beruas. Bunga betina lebih besar, berdiri sendiri sepanjang sumbu tandan. Bakal buah berbentuk bola buah bulat elips, kadang diluarnya berbulu, lapian luar berdaging, endosperm licin, tidak membuka, dalam tandan menggantung (Munawaroh, 2000).

\subsection{Manfaat Genus Baccaurea}

Anggota Baccaurea ini dipelihara terutama untuk hasil buahnya. Buah yang segar mungkin lebih populer jika kultivar yang rasanya asam diganti dengan yang manis, dan jika dagingnya tidak menempel pada bijinya (karenanya biji sering ditelan). Buahnya juga dimanfaatkan untuk asinan, atau difermentasi menjadi anggur. Baccaurea umumnya menghasilkan kayu yang baik sekali, 
merupakan produk utama berbagai jenis minor, walaupun untuk beberapa jenis buahnya dapat dimakan juga. Kayunya digunakan untuk bangunan rumah, perahu, dan mebel, selain itu sama halnya dengan pohon-pohon kauliflora lainnya, Baccaurea juga dianggap sebagai pohon perambat yang baik untuk rotan. Jenisjenis yang dibudidayakan membentuk tajuk yang bagus dan dapat dimanfaatkan juga sebagai tanaman hias dan pohon pelindung. Kulit kayu beberapa jenis anggota baccaurea dapat dicampur dengan dicampur berbagai ramuan, digunakan untuk mewarnai sutra menjadi kuning, merah, atau lembayung muda, melalui proses pewarnaan. Kulit kayu ini digunakan juga untuk mengobati mata bengkak. (Prihadi, 2011).

\subsection{Syarat Tumbuh Genus Baccaurea}

Habitat alami Baccaurea adalah hutan tropik dataran rendah. Tumbuh baik di hutan tropik dataran rendah lembap, lebih sering tumbuh di bawah $500 \mathrm{~m} \mathrm{dpl.,}$ walaupun ada beberapa anggota genus baccaurea yang dapat tumbuh diatas 500 m dpl seperti rambai $(750 \mathrm{~m} \mathrm{dpl})$ dan kapundung (1000 m dpl). Marga ini banyak dijumpai pada tipe-tipe tanah yang luas variasinya, dari tanah pasir yang kering sampai rawa gambut, tetapi jenis-jenis ini tampaknya bereaksi baik terhadap tanah yang lebih baik, contohnya rambai menyenangi tanah aluvial di dekat sungai atau di tempat-tempat yang mudah terjangkau air. (Prihadi, 2011).

\subsection{Botani Tanaman Sijontiak (Baccaurea polyneura)}

Pohon sijontiak secara sekilas mirip dengan pohon rambai. Daun memiliki bentuk oblong, memiliki panjang daun 12 hingga 15 centimeter $(\mathrm{cm})$, lebar daun 4 hingga $6 \mathrm{~cm}$, serta memiliki warna daun hijau tua. Bunganya kecil, banyak, bergerombol pada tangkai buah yang berjuntai sepanjang 20 hingga 30 sm dari dahan tua. Buah jentik-jentik / sijontiak (Baccaurea polyneura) yang mirip dengan buah rambai, buahnya bergantung-gantung pada tangkai, berwarna kekuningan dan bertukar kemerahan apabila masak. Terdapat tiga biji dalam satu buah dan isi daging buahnya berwarna merah. Rasanya umumnya manis dengan sedikit asam. Spesies Baccaurea Hookeri yang juga dikenali sebagai jentik-jentik mempunyai buahnya yang seakan-akan buah rambai tetapi lebih besar sedikitdaripada buah jentik-jentik merah. Apabila cukup masak ia berwarna 
kuning keperangan. Buah yang cukup masak apabila dijentik terus terbuka. Tiga bijinya berwarna kemerahan. Pembiakannya adalah dengan biji. Penanamannya memerlukan tanah yang subur (Anonim, 2011).

\subsection{Pentingnya Keragaman Plasma Nutfah}

Indonesia dikenal sebagai Negara yang memiliki keanekaragaman hayati tinggi, termasuk keragaman plasmanutfah pada taraf di dalam spesies. Plasmanutfah atau sumber daya genetik adalah bahan dari tumbuhan, hewan, jasad renik, yang mempunyai fungsi dan kemampuan mewariskan sifat. Sumber daya ini sebagian telah dimanfaatkan secara nyata dan masih banyak lagi yang belum dimanfaatkan (Hanarida, 2007).

Plasma nutfah adalah potensi genetik dari makhluk hidup. Keragaman plasma nutfah memungkinkan organisme untuk beradaptasi dengan perubahan kondisi lingkungan. Tidak ada satu individu dari spesies manapun yang mengandung semua keragaman genetik dari spesies ini. Ini berarti bahwa total potensi genetik hanya terwakili di dalam populasi yang terdiri dari banyak individu. Potensi genetik seperti itu disebut genepool. Potensi yang terdapat di dalam genepool merupakan dasar atau fondasi bagi tanaman pertanian kita, kehutanan, ternak dan sebagainya. Plasma nutfah hanya dapat dipelihara dalam jaringan yang hidup seperti pada embrio dari biji. Bila biji mati maka hilanglah plasma nutfah (Ardi, 2006).

Peningkatan kebutuhan areal lahan untuk berbagai sektor kebutuhan menyebabkan luas areal hutan dan pertanian semakin menyusut. Pembukaan lahan hutan yang tidak didahului dengan tindakan koleksi dan inventarisasi keberadaan tanaman yang ada dapat mengakibatkan hilangnya sumber daya genetik tanaman tertentu, disamping itu gencarnya penggunaan varietas unggul baru untuk berbagai jenis tanaman juga berdampak menyusutnya berbagai macam keragaman tanaman lokal. Padahal, keberadaan keragaman varietas lokal kemungkinan mempunyai arti penting secara genetik untuk sifat-sifat tertentu (Mangoendidjo, 2003).

Plasma nutfah merupakan bahan dasar untuk merakit varietas unggul yang mempunyai sifat-sifat diantaranya produktifitas tinggi, tahan hama dan penyakit, dan mutu yang sesuai dengan selera masyarakat. Untuk merakit varietas unggul 
diperlukan keanekaragaman plasma nutfah, maka kelestariannya harus selalu dijaga (Hanarida, 2007). Menurut Mangoendidjo (2003), untuk mengurangi laju penyusutan keberadaan keragaman berbagai jenis tanaman, maka perlu diadakan upaya penyelamatan dengan mengadakan koleksi dan inventarisasi.

Plasma nutfah ini diantaranya dapat sebagai sumber untuk sifat resistensi dan toleransi biotik maupun abiotik, serta sebagai sumber untuk nilai nutrisi, obat, dan biodiesel. Sumber- sumber gen tersebut sangat penting dalam program pemuliaan baik secara konvensional maupun dengan rekayasa genetik (modern) melalui perakitan, pelestarian, dan evaluasi. Erosi sumber daya genetik bias mengancam keamanan pangan dunia yang disebabkan oleh budidaya intensif varietas unggul pengganti varietas lokal, pembukaan lahan baru apalagi jika sumber daya genetic tersebut belum terexplorasi, disamping itu perubahan metode budidaya dari multikultur ke monokultur juga dapat menyebabkan erosi sumber daya genetic tanaman (Swasti, 2007)

Peran penting dari keberadaan sumber daya genetik tanaman terus mendorong para pemulia dan ahli taksonomi melakukan eksplorasi. Kegiatan eksplorasi dapat dilakukan di daerah sentra produksi, daerah produksi tradisional, daerah terisolir, daerah pertanian lereng-lereng gunung, pulau terpencil, daerah suku asli, daerah dengan system pertanian tradisional, daerah dimana masyarakatnya menggunakan komoditas yang bersangkutan sebagai makanan pokok, daerah epidemic hama dan penyakit. Pengumpulan sumber daya genetik. Pengumpulan sumber daya genetik tanaman dapat dijadikan koleksi untuk menjamin tersedianya keragaman genetik yang akan dimanfaatkan dalam pemuliaan tanaman (Swasti, 2007)

Keanekaragaman pada pada populasi tanaman yang digunakan mempunyai arti sangat penting. Besar kecilnya keragaman dan tinggi rendahnya rata-rata populasi tanaman yang digunakan sangat menentukan keberhasilan pemuliaan tanaman. Misalnya, bila kita hendak mengadakan pemuliaan untuk mendapatkan suatu varietas baru dengan produksi yang tinggi maka populasi yang digunakan sebagai populasi dasar atau populasi awal, disamping mempunyai variabilitas yang besar, akan lebih baik disertai rata-rata produksi yang relative tinggi ( Mangoendidjo, 2003) 
Dalam suatu populasi senatiasa akan ditemukan perbedaan diantara individu-individu penyusun populasi tersebut. Secara genetik sebenarnya dua tanaman tidak akan sama. Sudah banyak laporan penelitian yang dipublikasikan bahwa terdapat atau ditemukan keragaman baik dalam spesies maupun antar spesies tanaman. Keragaman yang ditemukan meliputi sifat morfologi atau yang tampak (fenotip) maupun yang tidak tampak (genetik). Keragaman dalam spesies maupun antar spesies telah banyak pula ditemukan, misalnya warna mahkota pada kedelai, bentuk buah tomat, warna bunga angrek, bulu rambutan, bentuk buah, rasa buah dan lain sebagainya (Swasti, 2007).

Variabilitas diantara karakter tanaman bias digolongkan kedalam variabilitas karakter kualitatif yaitu karakter yang dapat dengan mudah dibedakan kedalam kelas kelas-kelas tertentu (warna, bentuk, tekstur). Karakter kualitatif dikendalikan oleh satu atau dua gen mayor dan sedikit sekali dipengaruhi oleh lingkungan, biasanya dipakai sebagai penciri suatu kultivar. Variabilitas karakter kuantitatif yakni karakter yang jika diklasifikasikan akan bertingkat dari satu ekstrim ke ekstrim lain, maka tidak dapat dibedakan kedalam kelas-kelas tertentu seperti halnya pada sifat kualitatif. Karakter ini sangat dipengaruhi oleh lingkungan (missal tinggi tanaman, komponen hasil ,dan hasil) (Swasti, 2007) 


\section{BAHAN DAN METODA}

\subsection{Waktu dan Tempat}

Penelitian ini telah dilaksanakan dari bulan Maret sampai bulan Juni 2012, di Kecamatan Guguak, Kabupaten Lima Puluh Kota, Sumatera Barat. Jadwal kegiatan dapat dilihat pada (Lampiran 1)

\subsection{Bahan dan Alat}

Bahan yang digunakan dalam penelitian ini, meliputi : bagian dari tanaman sijontiak seperti daun, bunga, batang, biji, dan buah, sedangkan alat-alat yang digunakan meliputi: lembaran kuisioner (dapat dilihat pada Lampiran 3), meteran, timbangan, kantong, asam askorban, colour chart, list descriptor (dapat dilihat pada Lampiran 2), kamera digital, tali plastik, GPS (Global Position system), kertas label, pinset, busur, refaktometer, jangka sorong dan alat-alat tulis.

\subsection{Metode Penelitian}

Penelitian ini dilakukan dengan menggunakan metode survei dan pengambilan sampel dari tanaman sijontiak ini dilakukan secara sengaja (Purposive Sampling) yaitu sampel diambil berdasarkan unsur-unsur yang dikehendaki telah ada dalam anggota sampel yang diambil (Nasution, 2003). Penetapan sampel tanaman sijontiak di Kecamatan Guguak, Kabupaten Lima Puluh Kota ditentukan setelah melaksanakan survei pendahuluan dengan kriteria tanaman yang di inventarisasi adalah tanaman yang sudah pernah berbuah, baik yang dibudidayakan maupun yang tidak dibudidayakan. Data yang dikumpulkan berupa hasil dari pengukuran beberapa parameter pengamatan tanaman sijontiak dan hasil dari kuisioner. Pengolahan data dilakukan secara deskriptif yaitu menggambarkan ciri-ciri morfologi sesuai pengamatan terhadap seluruh tanaman dengan penyajian data dalam bentuk tabel, sedangkan untuk analisis kemiripan dengan menggunakan program NTSYS $\mathrm{Nc}_{\mathrm{p}} 2.02 \mathrm{i}$.

\subsection{Pelaksanaan}

\subsubsection{Survei Pendahuluan}

Pelaksanaan survei pendahuluan bertujuan untuk mengetahui keberadaan populasi tanaman sijontiak yang terdapat di Kecamatan Guguak, Kabupaten Lima Puluh Kota informasi diperoleh dari masyarakat, instansi terkait, serta pencarian 
langsung di lapangan tempat keberadaan tanaman sijontiak. Penetapan tanaman yang di inventarisasi dilakukan dengan pemberian kode berdasarkan daerah penelitian. Dari survei pendahuluan yang telah dilakukan ditetapkan Kecamatan Guguak sebagai tempat penelitian.

\subsubsection{Inventarisasi Tanaman Sijontiak}

\subsubsection{Pengambilan Data Primer}

Data primer didapatkan dari pengamatan langsung terhadap seluruh tanaman sijontiak yang sudah pernah berbuah. Data didapatkan dengan cara mengamati, mengukur, dan menanyakan langsung kepada petani/pemilik tanaman tentang segala yang berhubungan dengan variable pengamatan dan kuisioner. Acuan variabel pengamatan bagian morfologi tanaman sijontiak yang lebih lengkap dapat dilihat pada Lampiran 2

\subsubsection{Pengambilan Data Skunder}

Data skunder diperoleh dari informasi yang didapatkan dari petani serta penduduk di kanagarian yang dijadikan daerah penelitian, balai penyuluh pertanian (BPP) dan lembaga instansi yang terkait yang terdapat di Kecamatan Guguak, Kabupaten Lima Puluh Kota. Acuan variabel pengamatan bagian morfologi tanaman sijontiak yang lebih lengkap dapat dilihat pada Lampiran 3

\subsection{Pengamatan}

Pengamatan dan pengumpulan data dilakukan dengan cara melihat, mengukur dan mengamati ciri-ciri morfologi tanaman sijontiak (bunga, batang, daun, biji dan buah). Pemilik tanaman sijontiak selaku responden juga di ajukan pertanyaan-pertanyaan tentang segala yang berhubungan dengan variabel pengamatan, sebagaimana yang tersaji dalam lampiran.

\subsubsection{Data Primer}

Data primer didapat dengan pengamatan dan pengumpulan data yang dilakukan terhadap seluruh tanaman sijontiak yang sudah berbuah, untuk melihat, mengamati dan mengukur karakter morfologis tanaman sijontiak dilapagan meliputi ;

\section{a. Lokasi Tanaman}

Data yang diambil berupa tinggi tempat, posisi geografis, jorong nagari, kecamatan, kabupaten dari sumber lokasi. Titik koordinat keberadaan tanaman 
dapat diketahui melalui pengukuran langsung dengan penggunaan GPS (Global Position System). Pengukuran tersebut dapat dilakukan dengan cara mengaktifkan GPS tersebut pada masing-masing lokasi tanaman sijontiak di Kabupaten Lima Puluh Kota.

\section{b. Tinggi Tanaman (m)}

Tinggi batang diukur dari pangkal batang sampai puncak tertinggi, dengan cara mengukur sudut pandang sampai puncak tertinggi menggunakan alat pengukur sudut. Alat bantu yang digunakan untuk mengukur tinggi tanaman adalah dengan menggunakan busur derajat. Bandul dibuat dari benda yang berat hal ini bertujuan agar tidak mudah bergoyang-goyang. Pada sudut 90 derajat ditempeli sedotan yang tegak lurus untuk tempat membidik objek. Cara menggunakannya adalah dengan membidik puncak suatu objek melalui sedotan, maka dengan sendirinya tali akan menunjukan sudut ketinggian objek.

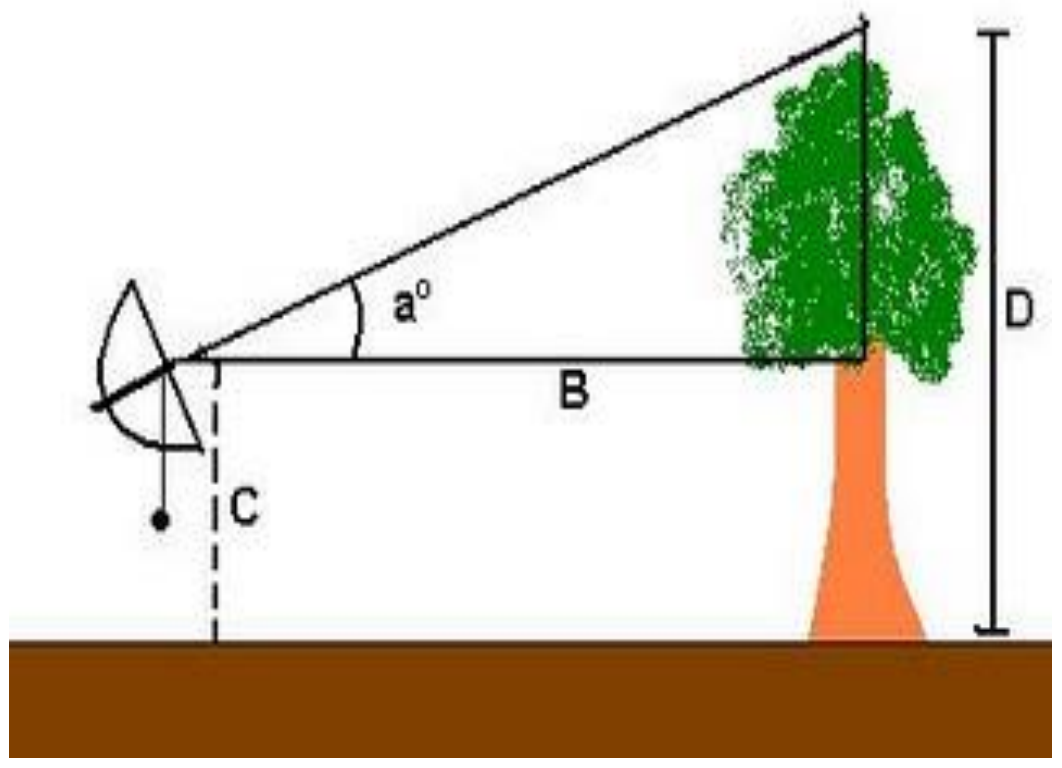

Gambar 1. Metode Pengukuran Tinggi Tanaman

Rumus: $\mathrm{D}=\mathrm{B} \times$ Tan $\alpha+\mathrm{C}$

Keterangan

$\mathrm{D}=$ Tinggi Tanaman

$\mathrm{B}=$ Jarak objek terhadap pengamat

$\mathrm{C}=$ Tinggi Pengamat

$\alpha^{\mathrm{o}}=$ Sudut mata terhadap ujung batang 


\section{c. Bentuk Tajuk/Kanopi}

Bentuk tajuk dapat diamati langsung pada batang, apakah bentuk tajuk pada batang tersebut pyramidal, oblong, spherical, semi-circular, elliptical, dan irregular (sesuai Lampiran 2).

\section{d. Karakteristik Batang}

\section{1) Permukaan Batang}

Permukaan batang dapat diamati langsung pada batang, apakah permukaan batang halus, agak kasar, kasar,dan sangat kasar (sesuai Lampiran 2).

\section{2) Arah tumbuh batang}

Arah tumbuh batang dapat diamati langsung pada batang, apakah arah tumbuh batang keatas, keluar, atau kebawah (sesuai Lampiran 2).

\section{3) Tipe Percabangan}

Tipe percabangan dapat diamati langsung pada batang, apakah tipe percabangan tersebut erect, intermediate, spreading (sesuai Lampiran 2).

\section{4) Bentuk Penampang Luar Batang}

Bentuk penampang melintang dapat diamati langsung pada batang, apakah bentuk penampang melintang tersebut bulat atau bersegi (sesuai Lampiran 2)

\section{5) Warna Kulit batang}

Warna kulit batang dapat diamati secara visual dengan menggunakan colour chart.

\section{6) Lingkaran Batang (m)}

Lingkaran batang, diukur $1 \mathrm{~m}$ dari permukan tanah dengan menggunakan tali dan meteran sebagai alat pengukur.

\section{e. Karakteristik Daun}

Daun yang diambil merupakan daun ke 4 dari ujung cabang batang dengan 3 posisi pengambilan yang berbeda. Cabang batang yang dipilih merupakan cabang batang yang paling dekat dengan batang utama dan permukaan tanah.

\section{1) Ujung daun (Apex)}

Ujung daun dapat diamati langsung pada tanaman, apakah ujung daun tersebut termasuk runcing, meruncing, tumpul, membulat, romping, terbelah, dan berduri (sesuai Lampiran 2). 


\section{2) Tepi daun (Margo)}

Tepi daun dapat diamati langsung pada tanaman apakah tepi daun tersebut rata, bergerigi, bergerigi ganda, bergiri, beringgit, dan berombak (sesuai Lampiran 2).

\section{3) Permukaan Daun}

Permukaan daun dapat kita rasakan secara langsung, apakah permukaan daun halus, kasar, sangat kasar (sesuai Lampiran 2)

\section{4) Panjang Helaian Daun (cm)}

Panjang helaian daun dapat diukur mulai dari ujung helaian daun sampai ke pangkal helaian daun dengan menggunakan meteran.

\section{5) Lebar Helaian Daun (cm)}

Lebar helaian daun diukur mulai dari pinggir bagian yang terluas dari daun yang tegak lurus dari tulang daun sampai pinggir daun dengan menggunakan meteran.

\section{6) Tulang Daun}

Tulang daun dapat diamati langsung pada tanaman, apakah tulang daun tanaman tersebut menyirip, menjari, melengkung, dan sejajar (sesuai lampiran 2)

\section{7) Panjang Tangkai Daun (cm)}

Panjang tangkai daun dapat diukur mulai pangkal tangkai daun sampai ke ujung tangkai daun dengan menggunakan meteran

\section{8) Pangkal Daun}

Pangkal daun dapat diamati langsung pada tanaman, apakah pangkal daun tanaman tersebut runcing, meruncing, tumpul, membulat, rompang dan berlekuk (sesuai lampiran 2)

\section{9) Bentuk Helaian Daun}

Ujung daun dapat diamati langsung pada tanaman, apakah ujung daun tersebut termasuk obovate-lanceolate, oblong, linear-oblong, elliptic, ovate, obovatus dan obovate (sesuai Lampiran 2).

\section{0) Warna Daun}

Diamati secara visual, dengan melakukan pengamatan secara langsung menggunakan colour chart. 


\section{1) Tipe Daun}

Berdasarkan kelengkapan daun, tipe daun dapat diamati langsung pada tanaman, apakah tipe daun tersebut termasuk daun lengkap atau daun tidak lengkap.

\section{f. Karakteristik Buah}

Untaian buah yang diambil merupakan untaian buah ke 4 dari ujung cabang batang dengan 3 posisi pengambilan yang berbeda. Cabang batang yang dipilih merupakan cabang batang yang paling dekat dengan batang utama dan permukaan tanah.

\section{1) Bentuk buah}

Bentuk buah dapat diamati langsung pada tanaman, apakah buah tersebut oblate, glubose, oval, oblong, elliptic, obovoid, dan ovoid (sesuai Lampiran 2).

\section{2) Pematangan Buah}

Pematangan buah dapat diamati langsung dilapangan, apakah pematangan buah tersebut merata atau tidak merata (sesuai Lampiran 2).

\section{3) Panjang Tangkai Utama Buah (cm)}

Panjang tangkai utama buah dapat diukur langsung pada tanaman. Pengukuran dimulai dari pangkal tangkai utama sampai ke ujung tangkai utama buah dengan menggunakan meteran.

\section{4) Ketebalan Daging (cm)}

Ketebalan daging buah dapat diukur pada tanaman dengan menggunakan jarum pentul dan kertas millimeter, jarum pentul ditusuk ke daging buah kemudian jarum pentul dikeluarkan dan ditempelkan di kertas millimeter, bagian kertas millimeter yang basah kemudian diukur dan didapatkanlah ketebalan daging buah tanaman sijontiak, apakah ketebalan buah tersebut tipis, medium, tebal, dan sangat tebal (sesuai Lampiran 2).

\section{5) Bentuk Ujung Buah}

Bentuk ujung buah dapat diamati langsung pada tanaman, apakah ujung buah tersebut Pointed, Convex, Mammiform, Truncate, Depressed (sesuai Lampiran 2). 


\section{6) Bentuk Pangkal Buah}

Bentuk pangkal buah dapat diamati langsung pada tanaman, apakah Pangkal buah tersebut Depressed, Necked, Convex, Truncate, Concave, Acute (sesuai Lampiran 2).

\section{7) Rasa Daging Buah}

Rasa daging buah dapat diketahui dengan uji organoleptik, panelis yang melakukan uji organoleptik 1 jam sebelum pengujian tidak boleh mencicipi rasa manis, selesai menguji satu sampel diberikan minum agar rasa yang sebelumnya tidak berpengaruh pada pengujian berikutnya.

\section{8) Warna kulit buah}

Warna kulit buah dapat diamati secara visual dengan menggunakan colour chart.

\section{9) Warna Daging Buah}

Warna kulit batang dapat diamati secara visual dengan menggunakan colour chart

\section{0) Berat Satu Buah (gram)}

Berat buah dapat ditimbang dengan meletakan satu buah sijontiak diatas timbangan, buah yang ditimbang merupakan buah yang ke 4 dari untaian buah.

\section{1) Kadar Gula Buah}

Kadar gula buah sijontiak dapat diukur dengan menimbang buah tanaman sijontiak seberat 100 gram. Kemudian buah tersebut dihancurkan dan disaring dengan kapas sehingga berbentuk cairan, selanjutnya cairan tersebut diteteskan ke refraktometer dan akhirnya pada alat akan tebaca persentase kandungan kadar gulanya. Kadar gula pada buah sijontiak tersebut apakah asam, manis dengan sedikit asam, sedikit manis, manis sekali (sesuai Lampiran 2).

\section{2) Jumlah Buah Per Tandan/ per untaian}

Jumlah buah per tandan dapat diamati langsung pada tanaman, caranya dengan menghitung jumlah 1 untaian dari buah sijontiak tersebut.

\section{3) Panjang Tangkai Buah (cm)}

Panjang tangkai buah dapat diukur langsung pada tanaman. Pengukuran dimulai dari pangal tangkai buah yang berasal dari cabang tangkai buah utama sampai ke ujung tangkai buah. 


\section{4) Diameter Buah (cm)}

Diameter buah dapat diukur langsung pada tanaman. Pengukuran diameter buah dapat dihitung dengan memotong buah secara horizontal menggunakan jangka pada bagian buah yang paling lebar.

\section{g. Karakteristik Biji}

\section{1) Panjang Biji (cm)}

Panjang biji dapat diukur setelah biji dikering anginkan, panjang biji dapat diukur dari bagian atas biji sampai ke bagian bawah biji dengan menggunakan kertas millimeter.

\section{2) Lebar Biji (cm)}

Diameter biji dapat diukur setelah biji dikering anginkan, diameter diukur pada bagian biji yang terluas dengan menggunakan kertas milimeter.

\section{3) Jumlah Biji Satu Buah}

Jumlah biji dapat dihitung langsung pada buah, jumlah biji ini dihitung berdasarkan jumlah biji perbuah .

\section{4) Berat 100 Biji (gram)}

Berat biji dapat dihitung langsung setelah biji sebelumnya dikering anginkan, berat biji ditimbang dengan menimbang 100 biji dengan menggunakan timbangan.

\section{5) Bentuk Biji}

Bentuk biji dapat diamati langsung setelah biji dikering anginkan terlebih dahulu, apakah bentuk biji tersebut spheroid, ellipsoid, oblong, ovoid, dan obovoid (sesuai lampiran 2)

\section{6) Warna Kulit Biji}

Warna kulit biji dapat diamati secara visual dengan menggunakan colour chart.

\section{h. Letak Koordinat dengan GPS (Global Positioning System)}

Penentuan posisi tanaman sijontiak berdasarkan titik koordinatnya dilakukan dengan dengan alat GPS (Global Positioning System). GPS merupakan suatu alat tekhnologi pemantau posisi bumi yang memanfaatkan tekhnologi satelit. Untuk menjalankan system ini selain satelit GPS juga dibutuhkan perangkat penerima sinyal GPS. GPS receiver inilah yang berfungsi sebagai titik 
tujuan yang menentukan lokasi bumi. Lokasi dari posisi tanaman ini dapat diketahui dengan mengaktifkan GPS di dekat tanaman tersebut, lalu secara otomatis akan terlihat di dalam GPS letak koordinat dari sijontiak.

\section{i. Serangan Hama dan Penyakit}

serangan hama penggerek batang, penggerek buah, lalat buah, dll dan juga serangan jamur terutama pada batang.

\section{j. Dokumentasi}

Perbedaan dan keragaman hasil karakterisasi morfologi tanaman sijontiak yang diamati pada penelitian ini dapat dilihat berupa foto bagian-bagian tanaman sijontiak seperti batang, daun, bunga, buah, dan biji.

\subsubsection{Data Skunder}

Data sekunder didapatkan melalui wawancara kepada pemilik tanaman sijantiak berdasarkan pada kuisioner, selain itu ada data juga didapat dari Kantor Balai Penyuluh Pertanian (BPP) di kecamatan yang dijadikan daerah penelitian, serta lembaga instansi terkait lainya, di Daerah Tingkat II.

Data sekunder yang dikumpulkan meliputi: 1) Informasi dari pemilik tanaman sijontiak,badan penyuluhan pertanian setempat dengan mewawancarainya berdasarkan pada kuisioner, 2) pengelolaan tanaman sijontiak, 3) asal biji, jenis biji, budidaya, umur tanaman, serta masalah yang dihadapi peani bagi yang membudidayakanya, 4) lokasi tanaman, meliputi kabupaten, kecamatan, kanagarian, tinggi tempat dari permukan laut dan tipe iklim dari lokasi sumber lokasi.

\subsection{Analisis Kemiripan}

Analisis kemiripan bertujuan untuk mengetahui kedekatan kerabat antara satu jenis tanaman sijontiak dengan tanaman sijontiak lain yang didapatkan di lapangan. Data karakter morfologi tanaman sijontiak yang didapat akan diolah atau dianalisis dengan perangkat lunak komputer (software) program NTSYS $_{\mathrm{pc}} 2.02 \mathrm{i}$. Hasil dari kemiripan ini akan ditampilkan dalam bentuk dendogram.

\subsection{Variabilitas Fenotipik}

Untuk mengetahui luas atau sempitnya variabilitas karakter yang diamati maka dilakukan variabilitas fenotipik dan standar deviasi. Sijontiak yang 
dianalisis nilai variasi fenotipiknya adalah semua pengamatan yang diamati baik yang bersifat kualitatif maupun kuantitatif.

Nilai variasi fenotipik diketahui sebagai berikut:

$$
\sigma^{2} f=\frac{\sum(\mathrm{xi}-\overline{\mathrm{x}})^{2}}{\mathrm{n}-1}
$$

(Steel dan Torie, 1995)

Keterangan:

$\sigma^{2} f \quad=$ Ragam varians

$\mathrm{xi} \quad=$ Nilai variable ke $\mathrm{i}$

$\overline{\mathrm{X}} \quad=$ Nilai rata-rata variable

$\mathrm{n} \quad=$ Jumlah sampel yang diamati

standar deviasi variasi fenotip diketahui sebagai berikut:

$$
\mathrm{Sd}=\sqrt{\sigma^{2} f}
$$

(Anderson dan Brocot, 1952 dalam Derajat,1987)

Kriteria penilaian luas atau sempit variabilitas karakter yang diamati diketahui berdasarkan kriteria Derajat (1987), sebagai berikut:

$\sigma^{2} f>2 \times$ S.D berarti variabilitas fenotip luas

$\sigma^{2} f<2$ x S.D berarti variabilitas fenotip sempit 


\section{HASIL DAN PEMBAHASAN}

\subsection{Profil Kabupaten Lima Puluh Kota}

Kabupaten Lima Puluh Kota merupakan salah satu Kabupaten di Provinsi Sumatera Barat. Kabupaten Lima Puluh Kota mempunyai luas wilayah 3.354,30 $\mathrm{Km}^{2}$ yang berarti 7,94 persen dari daratan Provinsi Sumatera Barat yang luasnya 42.229,64 $\mathrm{Km}^{2}$. Kabupaten Lima Puluh Kota terdiri dari 13 Kecamatan dan 79 Nagari (Lampiran 4).

Berdasarkan letak geografis Kabupaten Lima Puluh Kota terletak antara $0^{\circ} 25^{\prime} 28,7^{\prime \prime} \mathrm{LU}$ dan $0^{\circ} 22^{\prime} 14,52^{\prime \prime L S}$ serta antara 100¹5'44,10" BB 10050'47,80"BT. Ketinggian 110 meter dan 2.261 meter di atas permukaan laut. Kabupaten Lima Puluh Kota mempunyai kondisi topografi didominasi oleh wilayah datar, bergelombang dan berbukit-bukit. Secara umum wilayah Kabupaten Lima Puluh Kota beriklim tropis dengan temperatur antara $20^{\circ} \mathrm{C}-25^{\circ} \mathrm{C}$, dengan curah hujan rata-rata berkisar antara 2200 sampai dengan $3750 \mathrm{~mm} /$ tahun (Badan Pusat Statistik kab.Lima Puluh Kota)

Kecamatan guguak merupakan salah satu kecamatan di Kabupaten Lima Puluh Kota, kecamatan guguak mempunyai luas wilayah 106,20 Km2 yang berarti 3,16 \% dari luas Kabupaten Limapuluh Kota yang luasnya 3.354,30 Km2. Terdiri dari 5 Nagari dan 30 jorong (Lampiran 5 ).

Berdasarkan letak geografis kecamatan guguak terletak antara $0^{\circ} 36^{\prime} 08^{\prime \prime}$ LU dan 100³9'03" LS, Topografi Kecamatan Guguak datar,berbukit dan bergelombang dengan ketinggian tempat terendah dari permukaan laut adalah Simpang Kuranji Nagari Guguak VIII Koto (510 m dpl) dan tertinggi di Bukit Pintu Angin Nagari Kubang (1.025m dpl) (Badan Pusat Statistik. 2011)

Sijontiak termasuk buah komersial karena dari hasil wawancara dengan masyarakat Kecamatan Guguak buah ini dapat menambah penghasilan si pemilinya. Pada saat musimnya buah yang masak dijual di pasar tradisional di Kabupaten Lima Puluh Kota, Bukitinggi, dan Batusangkar, namun keanekaragaman buah ini belum diketahui karakterisasinya dan belum pernah dilakukan koleksi plasma nutfahnya. 
Sesuai dengan profil Kabupaten Lima Puluh Kota tentang ketinggian daerahnya, maka sijontiak merupakan tanaman yang dapat dibudidayakan untuk menambah penghasilan masyarakat serta mempertahankan koleksi dari berbagai tanaman-tanaman lokal yang ada di daerah tersebut.

Kegiatan inventarisasi dan karakterisasi tanaman sijontiak telah dilakukan pada Kanagarian Guguak VIII Koto, Guguak VII Koto Talago, Kubang, Sungai Tolang, dan Simpang Sigiran yang ada di Kecamatan Guguak, Kabupaten Lima Puluh Kota. Pada daerah ini terdapat tanaman sijontiak yang memiliki karakteristik yang diminati masyarakat. Tanaman yang diamati diperoleh berdasarkan keterangan dari masyarakat setempat dengan kriteria tanaman yang diamati adalah tanaman yang sudah pernah berbuah baik yang dibudidayakan maupun yang tidak dibudidayakan.

Dari beberapa kanagarian yang ada di Kabupaten Lima Puluh Kota yang ditetapkan sebagai daerah penelitian didapatkan 63 aksesi. Adapun rincian jumlah aksesi per nagari dapat dilihat pada Tabel 1 .

Tabel 1. Rincian jumlah aksesi per nagari

\begin{tabular}{|c|l|c|}
\hline No & \multicolumn{1}{|c|}{ Kanagarian } & Jumlah Aksesi \\
\hline 1 & Guguak VIII Koto & 35 \\
\hline 2 & Guguak VII Koto Talago & 11 \\
\hline 3 & Simpang Sigiran & 5 \\
\hline 4 & Kubang & 8 \\
\hline 5 & Sungai Tolang Jumlah & 4 \\
\hline \multicolumn{2}{r}{ Jum } \\
\hline
\end{tabular}

Pengamatan di lapangan, populasi keberadaan tanaman sijontiak yang diamati terletak pada ketinggian 527-807 mdpl (Lampiran 7). Kanagarian guguak VIII koto sebagai tempat terendah dan kanagarian kubang sebagai tempat tertinggi, dimana tanaman sijontiak paling banyak di kanagarian Guguak VIII Koto dengan ketinggian 527-549 mdpl, sesuai dengan pendapat Haegens (2000) tanaman sijontiak dapat tumbuh pada ketinggian 20-600 m diatas permukaan laut. 


\subsection{Penampilan Morfologi}

\subsubsection{Morfologis Tanaman}

\section{a. Tinggi Tanaman}

Pohon Sijontiak ukurannya dapat mencapai ketinggian antara 20 meter hingga 25 meter (Anonim, 2011). Berdasarkan pengamatan yang telah dilakukan, tinggi tanaman ini berkisar antara 35-15 m tinggi tanaman yang paling tertinggi pada saat pengamatan terdapat pada aksesi BS-1 yaitu 35,60 $\mathrm{m}$ dan yang terendah pada aksesi BT-3 yaitu 15,56 m. Data morfologis tinggi tanaman sijontiak dapat dilihat pada Lampiran 8 dan keterangan mengenai kode aksesi dapat dilihat pada Lampiran 15.

\section{b. Bentuk Tajuk}

Bentuk tajuk tanaman sijontiak di daerah ini bermacam-macam, ada yang berbentuk oblong sebanyak 28\%, spherical sebanyak 27\%, phyramidal sebanyak 25\%, dan elliptical sebanyak 19\%. Sijontiak pada beberapa kanagarian di Kabupaten Lima Puluh Kota memiliki tipe arah tumbuh batang keatas sebanyak $79 \%$ dan keluar sebanyak $21 \%$ serta memiliki tipe percabangan erect sebanyak $44 \%$, intermediate sebanyak 40\%, dan spreading sebanyak $16 \%$ dari 63 aksesi tanaman. Penampilan bentuk tajuk tanaman disajikan pada Gambar 2 dan keterangan mengenai kode aksesi dapat dilihat pada Lampiran 15.

\subsubsection{Morfologi Batang}

Hasil pengamatan terhadap morfologis batang sijontiak di Kabupaten Lima Puluh Kota menunjukan adanya variasi antara semua aksesi yang dikumpulkan. Variasi antara semua aksesi dapat dilihat pada Lampiran 9 dan keteranagan mengenai kode aksesi dapat dilihat pada Lampiran 15. Berdasarkan data morfologi batang tanaman sijontiak tersebut dapat dilihat bahwa bentuk batang tanaman sijontiak dari 63 aksesi berdasarkan bentuk penampang bentuk luarnya adalah bulat (teres). lingkaran batang berkisar antara 50-310 cm, lingkaran batang yang terbesar terdapat pada aksesi BS-1 yaitu $302 \mathrm{~cm}$ dan yang terkecil pada aksesi GK-1 yaitu 51 cm. Menurut Marwan (1994) cit Rusli (2002), 
diameter batang akan meningkat ukurannya bila bahan makanan yang dibutuhkan tanaman berada dalam jumlah yang memadai dan diameter batang berkembang menurut pola tertentu sesuai dengan habitusnya.

Sifat kualitatif (permukaan batang dan warna batang) masing-masing aksesi ditemukan 3 macam batang tanaman sijontiak yaitu: 1) agak kasar sebanyak $31,74 \%, 2$ ) kasar sebanyak $58,73 \%$, 3) sangat kasar sebanyak 9,52\% untuk permukaan batang. Untuk warna batang yaitu: 1) abu-abu sebanyak 3,18 \%, 2) coklat sebanyak $41,27 \%, 3)$ coklat muda sebanyak $47,62 \%, 4)$ coklat tua $7,93 \%$.

Kombinasi dari kedua sifat kualitatif batang tersebut didapatkan 10 macam tipe tanaman sijontiak berdasarkan permukaan batang dan warna batang dari 63 aksesi tanaman sijontiak yaitu: 1) agak kasar-coklat sebanyak 7,9\%,2) agak kasar- coklat muda 22,22 \%, 3) kasar-abu-abu 1,59 \%, 4) kasar-coklat 30,16\%, 5) kasar-coklat tua 6,35\%,6) kasar-coklat muda 22,22\%,7) sangat kasar-abu-abu $1,59 \%, 8)$ sangat kasar-coklat 3,17\%, 9) sangat kasar-coklat tua 1,59\%, 10) sangat kasar-coklat muda 3,17\%. Penampilan semua batang tanaman sijontiak dapat dilihat pada Gambar 3 dan keterangan mengenai kode aksesi tanaman dapat dilihat pada Lampiran 15.
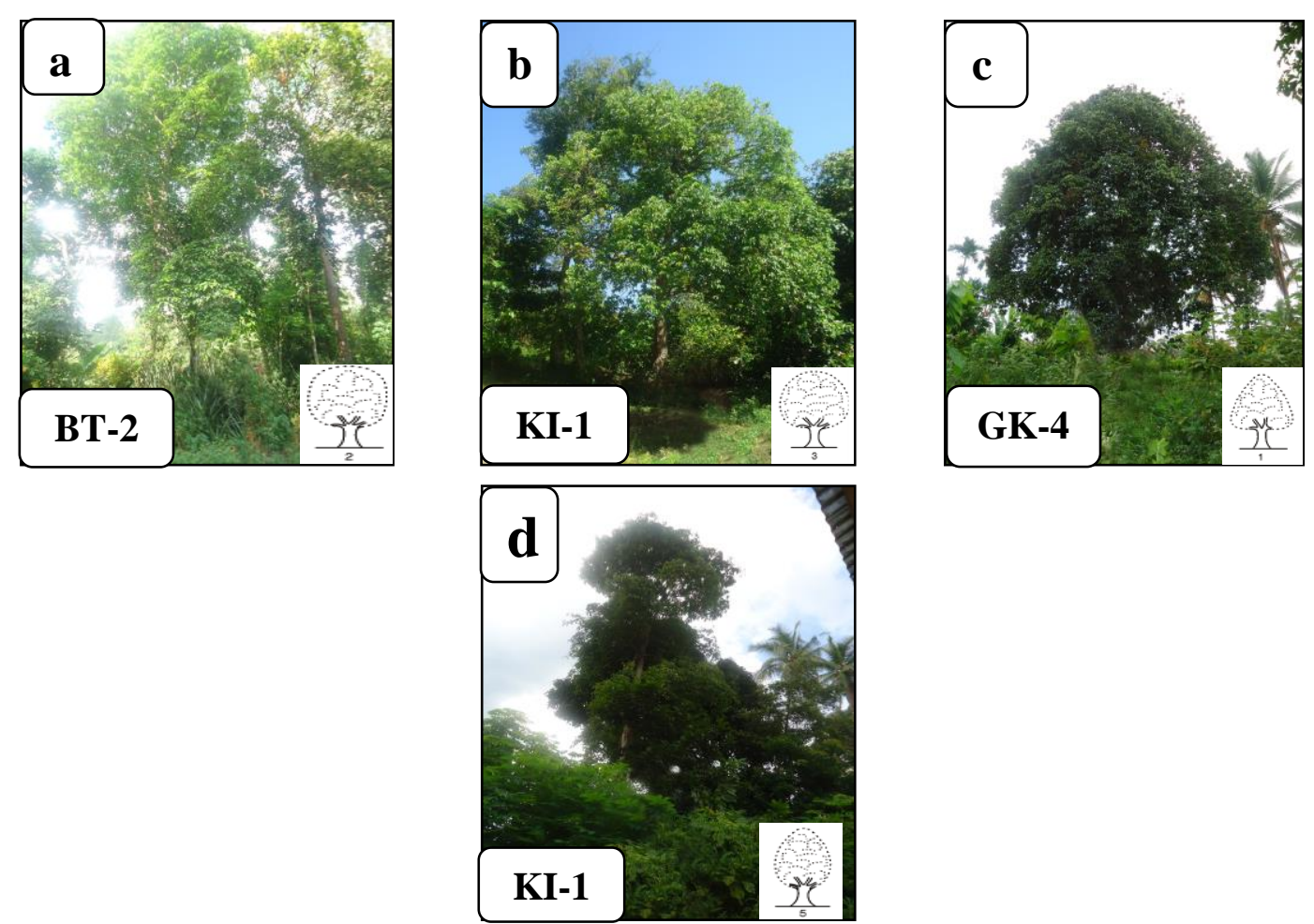

Gambar 2. Bentuk tajuk tanaman sijontiak (a. Oblong, b. Spherical, $c$. Phyramidal, d. Elliptical 

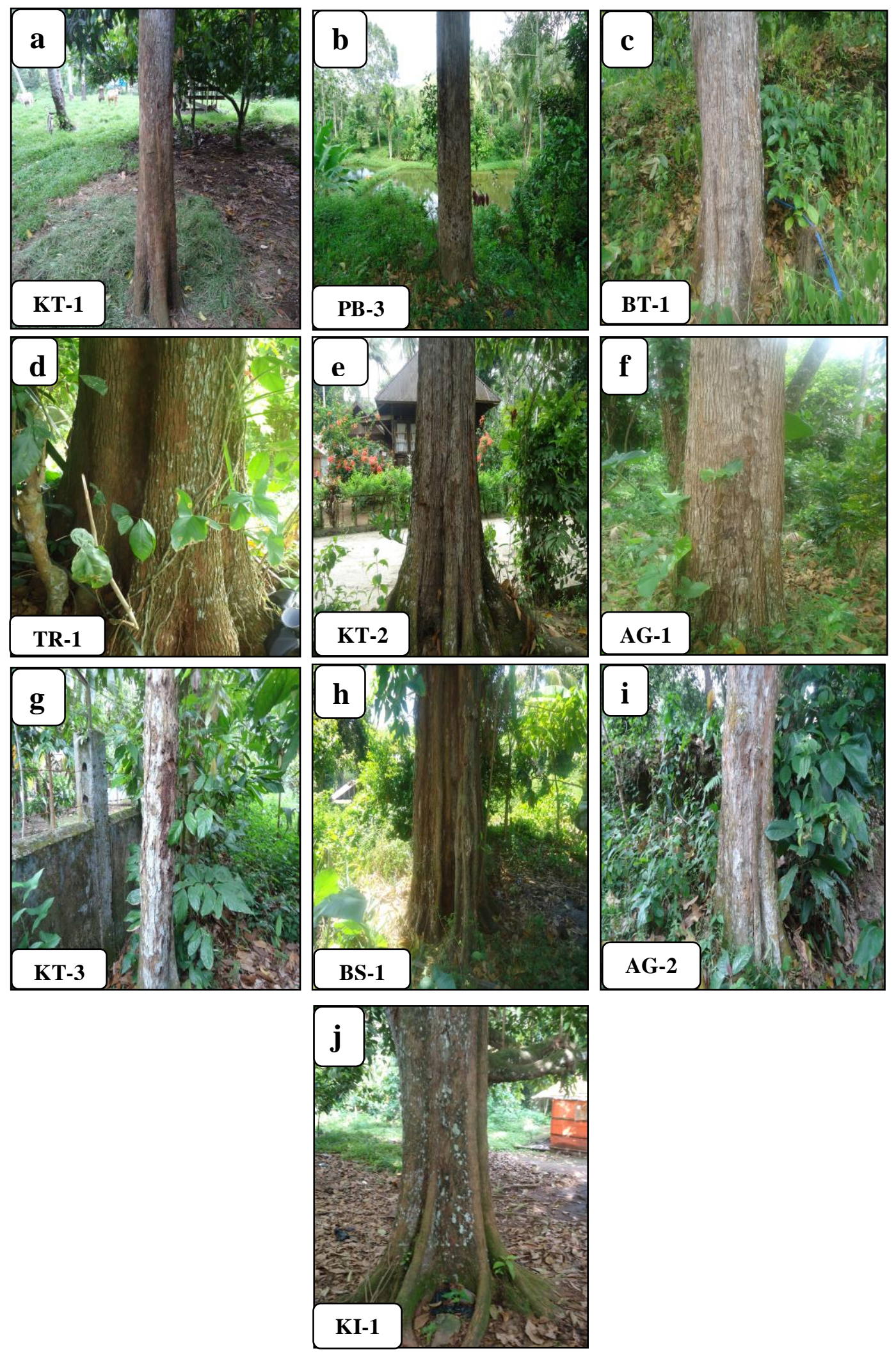

Gambar 3. Tipe batang tanaman sijontiak (a. agak kasar-coklat, b. agak kasarcoklat muda, c. kasar-abu-abu, d. kasar-coklat, e. kasar-coklat tua, f. kasar-coklat muda, g. sangat kasar-abu-abu, h. sangat kasarcoklat, i.sangat kasar-coklat tua, j. sangat kasar-coklat muda). 


\subsubsection{Morfologi Daun}

Hasil pengamatan terhadap karakter kuantitatif morfologi daun tanaman sijontiak yaitu panjang, lebar, dan panjang tangkai daun menunjukan adanya variasi antara keseluruhan aksesi yang ditemukan. Pada masing-masing aksesi panjang helaian daun berkisar antara $13-22 \mathrm{~cm}$ lebar helaian daun berkisar antara 5-10 cm, dan panjang tangkai daun berkisar antara 2-6 cm.

Helaian daun yang terpanjang terdapat pada aksesi $\mathrm{KN}-1$ yaitu $21,53 \mathrm{~cm}$ dan yang terpendek terdapat pada aksesi KG-1 yaitu sebesar 13,33 cm. Lebar daun yang terlebar terdapat pada aksesi $5 \mathrm{KT}-1$ sebesar 9,17 cm dan yang terkecil pada aksesi BT-2 sebesar 5,17cm . Panjang tangkai daun terpanjang terdapat pada aksesi BT-1 sebesar 5,83 cm dan yang terpendek pada aksesi KN-4 sebesar 2,67 $\mathrm{cm}$. Anonim (2011) menyatakan bahwa panjang helaian daun sijontiak berkisar antara 12-15 cm dan lebar 4-6 cm. selanjutnta Gardner et al tahun 1991 cit Yuanita (2006) menyatakan bahwa jumlah dan ukuran daun dipengaruhi oleh genotipe dan lingkungan. Semakin banyak jumlah daun dan didukung oleh intensitas cahaya yang tinggi, maka akan meningkatkan aktifitas fotosintesis sehingga hasil asimilat pun akan banyak dimana nantinya akan berpengaruh terhadap hasil panen.

Berdasarkan karakter kualitatif morfologi daun sijontiak didapatkan bahwa daun tanaman sijontiak merupakan daun tidak lengkap karena hanya memiliki tangkai daun dan helaian daun saja. Sijontiak memiliki tepi daun yang rata, tulang daunnya menyirip, memiliki pangkal daun yang kebanyakan membulat dan memiliki ujung daun yang meruncing. Bentuk helaian daun tanaman sijontiak yang telah diamati beranekaragam seperti elliptic sebanyak $71,4 \%$, ovate $25,36 \%$, obovatus 1,59\%, dan oblong 1,59\% dari 63 aksesi. Penampilan bentuk helaian daun dapat dilihat pada Gambar 4.

Permukaan daun tanaman sijontiak memiliki bentuk permukaan yang kasar sebanyak $73 \%$, halus $23,8 \%$, agak kasar 3,17\% dan memiliki warna daun hijau tua sebanyak 73\%, hijau 20,6\%, hijau muda 6,3\% dari 63 aksesi tanaman sijontiak. Menurut Tjitrosoepomo tahun 2005 cit Saputra (2007) warna daun suatu jenis tumbuhan dapat berubah menurut keadaan tempat tumbuhnya dan erat sekali hubungannya dengan persediaan dan makanan serta penyinaran. Penampilan warna daun dapat dilihat pada Gambar 5. 

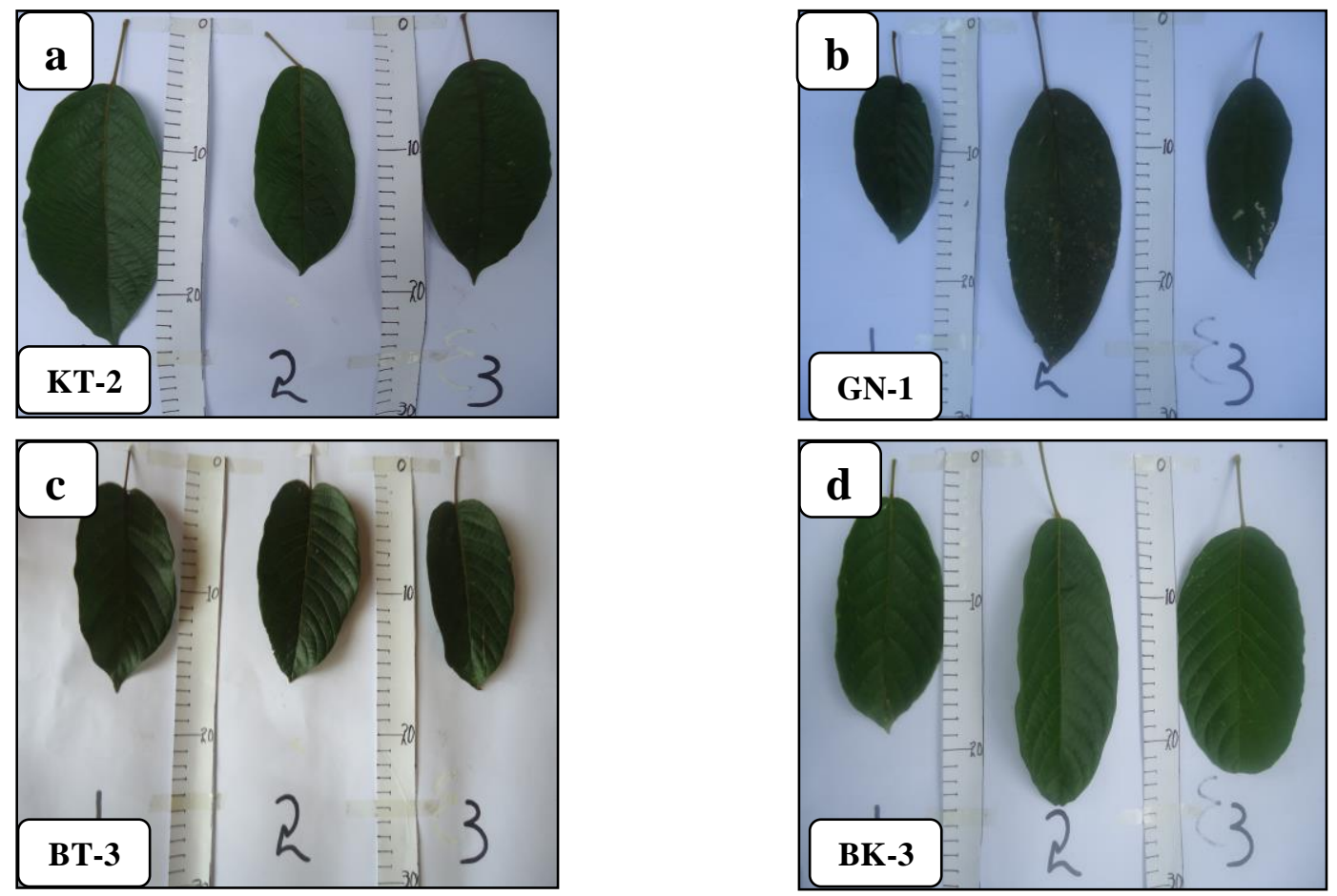

Gambar 4. Bentuk helaian daun sijontiak (a. elliptic, b. ovate, c. obovatus, $d$. oblong)
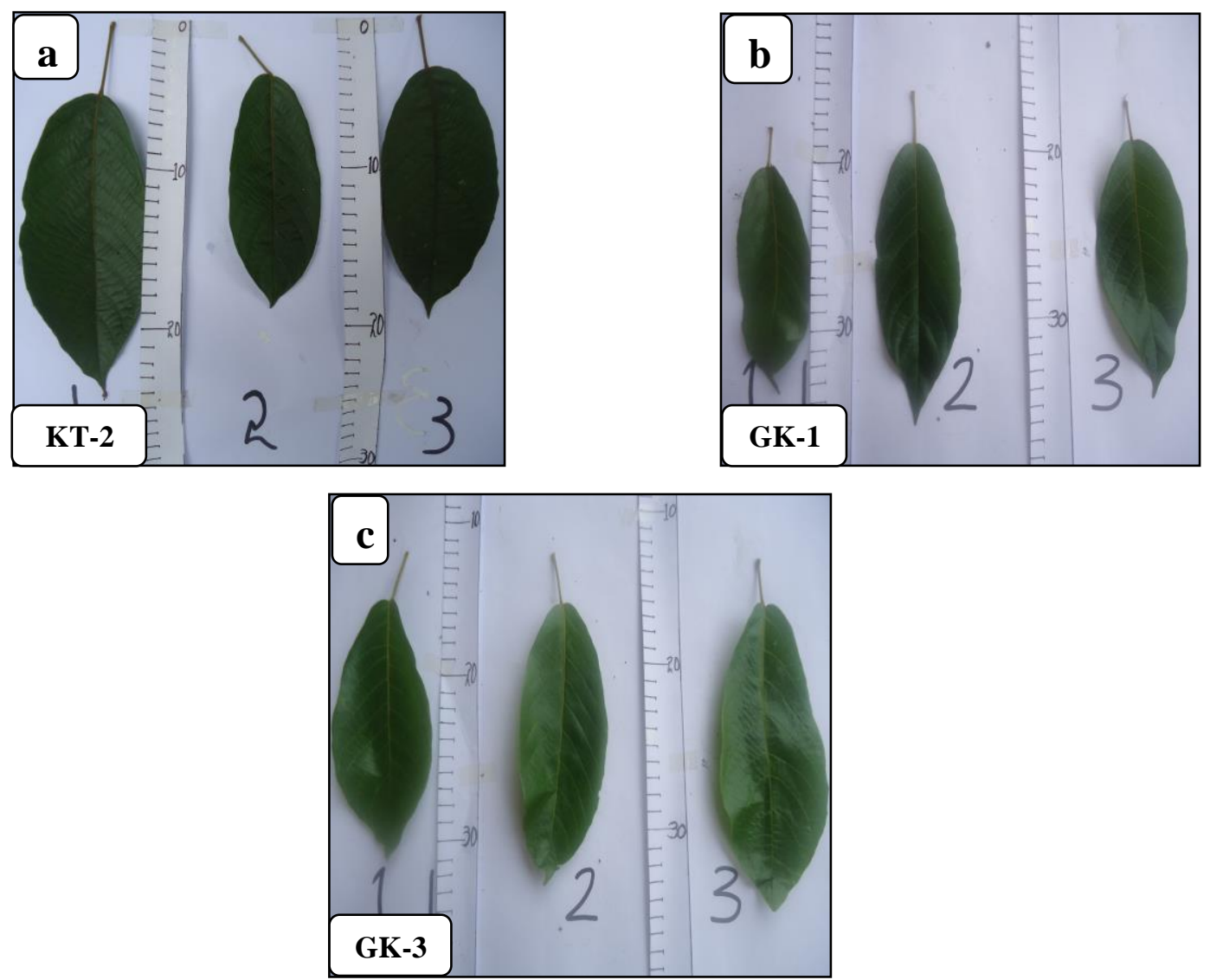

Gambar 5. Warna daun (a. hijau tua, b. hijau, c. hijau muda) 
Penampilan karakter kualitatif maupun kuantitatif morfologi daun masingmasing aksesi dapat dilihat pada Lampiran 10 dan keterangan mengenai kode aksesi tanaman dapat dilihat pada Lampiran 15.

\subsubsection{Morfologi Buah}

Pengamatan terhadap buah sijontiak tidak dapat dilakukan pada seluruh tanaman yang diamati, ini dikarenakan pada tanaman yang diamati ada yang sedang berbuah muda, sedang berbunga, dan ada juga yang sedang tidak berbuah. Informasi deskripsi mengenai morfologi buah di peroleh dari masyarakat setempat dan pemilik tanaman sijontiak dengan cara mencocokan dengan memakai panduan list descriptor tanaman sijontiak.

Dari hasil pengamatan yang telah dilakukan dimana jumlah aksesi yang buahnya masak adalah 27 aksesi, di dapatkan data kualitatif karakteristik buah sijontiak mulai dari bentuk buah seperti globose sebanyak 51,9\%, oblate sebanyak 44,4\% dan oval sebanyak 3,73\%. Rasa daging buah secara umum adalah manis dengan sedikit asam, jenis ujung buahnya adalah convex sebanyak 51,8\%, truncate sebanyak $44,4 \%$, pointed sebanyak $3,7 \%$ dan jenis pangkal buahnya truncate sebanyak 55,6\%, dan convex sebanyak 44,4\%. Warna daging buah orange tua sebanyak $66,7 \%$, orange sebanyak $9,5 \%$, dan orange muda sebanyak $11,1 \%$. Warna kulit buah berwarna orange tua sebanyak $66,7 \%$, orange kehitaman sebanyak $14,8 \%$, dan orange sebanyak $18,5 \%$. Penampilan bentuk buah, warna daging buah dan warna kulit buah dapat dilihat pada Gambar 6, Gambar 7, dan Gambar 8 .

Berdasarkan pengamatan yang telah dilakukan, didapatkan data kuantitatif karakteristik tanaman sijontiak sebagai berikut: panjang tangkai utama buah berkisar antara 6-45 cm, dimana panjang tangkai buah terpanjang terdapat pada aksesi KG-1 sebesar $45 \mathrm{~cm}$ dan yang terpendek terdapat pada aksesi BA-1 sebesar $6,3 \mathrm{~cm}$. Panjang tangkai buah secara umum adalah $1 \mathrm{~cm}$, diameter buah berkisar antara 1,4-3 cm, dimana diameter paling besar terdapat pada aksesi TR-1 sebesar $3 \mathrm{~cm}$ dan yang terkecil terdapat pada aksesi KI-4 sebesar 1,4 cm.

Ketebalan daging buah berkisar antara 1-4 mm, dimana daging buah yang paling tebal terdapat pada aksesi GK-4 sebesar $3,4 \mathrm{~cm}$ dan yang paling tipis terdapat pada aksesi GK-1 sebesar $1 \mathrm{~mm}$. Berat satu buah berkisar antara 2,2 -4,62 
gram, dimana buah paling berat terdapat pada aksesi ST-1 sebesar 4,62 dan yang paling ringan terdapat pada aksesi KI-1 sebesar 2,9. Jumlah buah per untaian berkisar antara 3-17 buah dimana jumlah buah per untaian yang paling banyak terdapat pada aksesi GK-4 sebanyak 17 buah dan yang paling sedikit terdapat pada aksesi SB-1 dan BA-1 sebanyak 4 buah. Penampilan karakter kualitatif maupun kuantitatif morfologi buah masing-masing aksesi dapat dilihat pada lampiran 11 dan keterangan mengenai kode aksesi tanaman dapat dilihat pada Lampiran 15.

Keadaan yang berbeda dapat menyebabkan perbedaan hasil dari suatu tanaman, seperti yang dijelaskan Yuleff (1999) cit Yuanita (2006) bahwa berdasarkan kenyataan, hasil dari suatu varietas sering berubah-ubah dari suatu lingkungan ke lingkungan lainnya. Hal ini disebabkan adanya interaksi antara genotip tanaman dengan lingkungan agroklimatnya. Stabilitas hasil suatu varietas ditentukan oleh kemampuan genotype tanaman untuk menghindari fluktuasi hasil pada berbagai lingkungan.
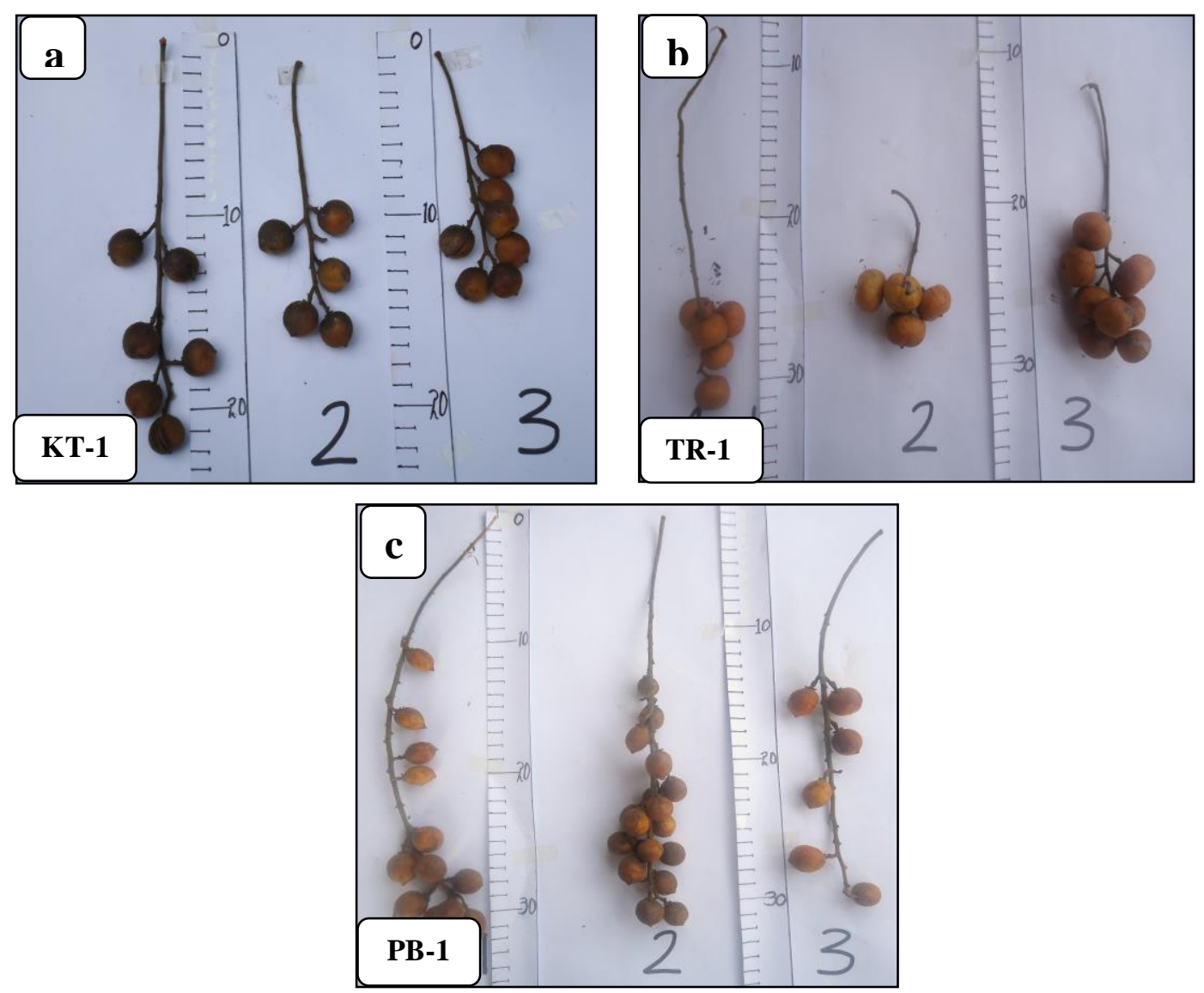

Gambar 6. Bentuk buah (a. globose, b. oblate, c. oval) 


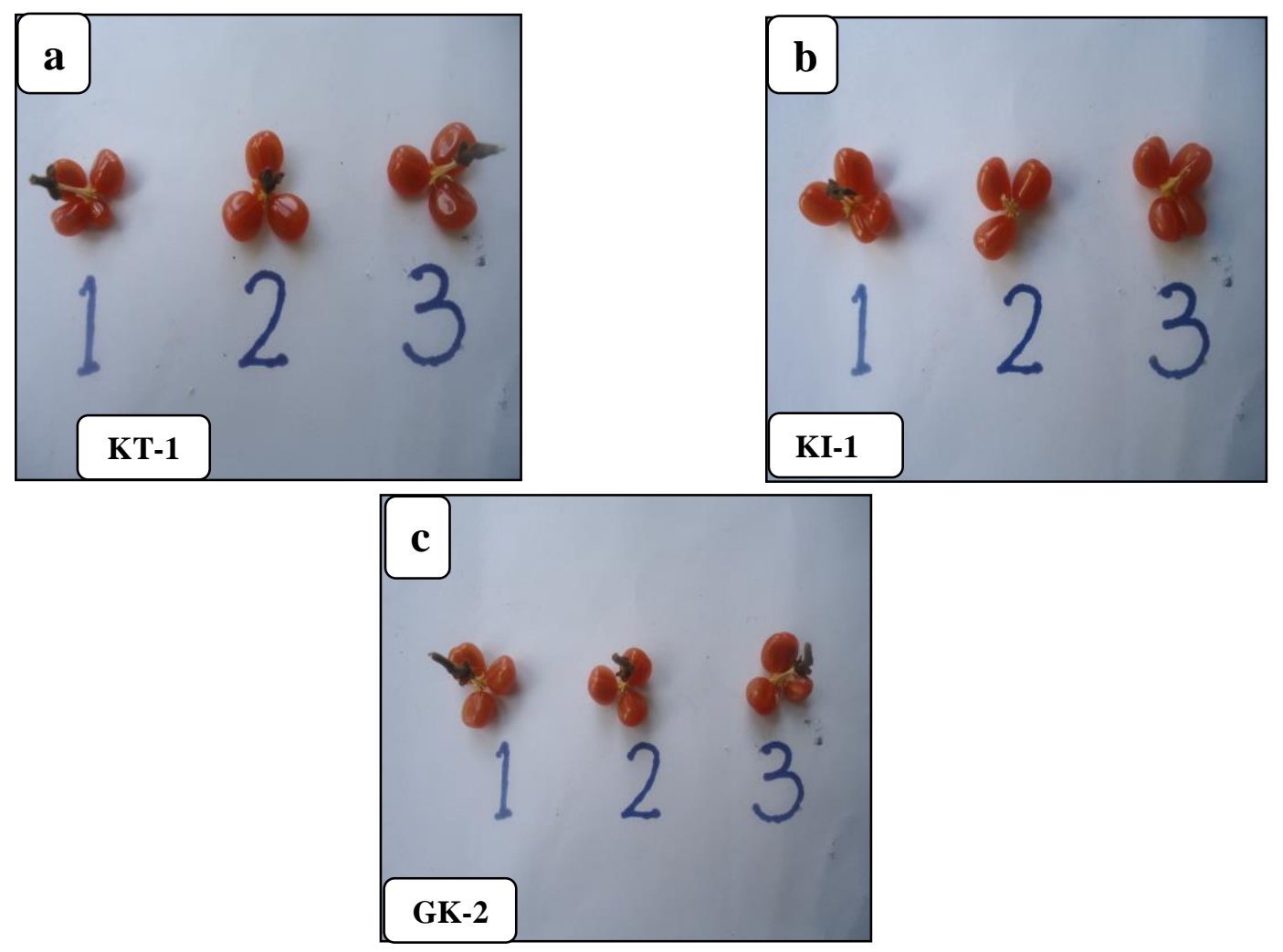

Gambar 7. Warna daging buah (a. Orange tua, $b$. Orange, c. Orange muda)

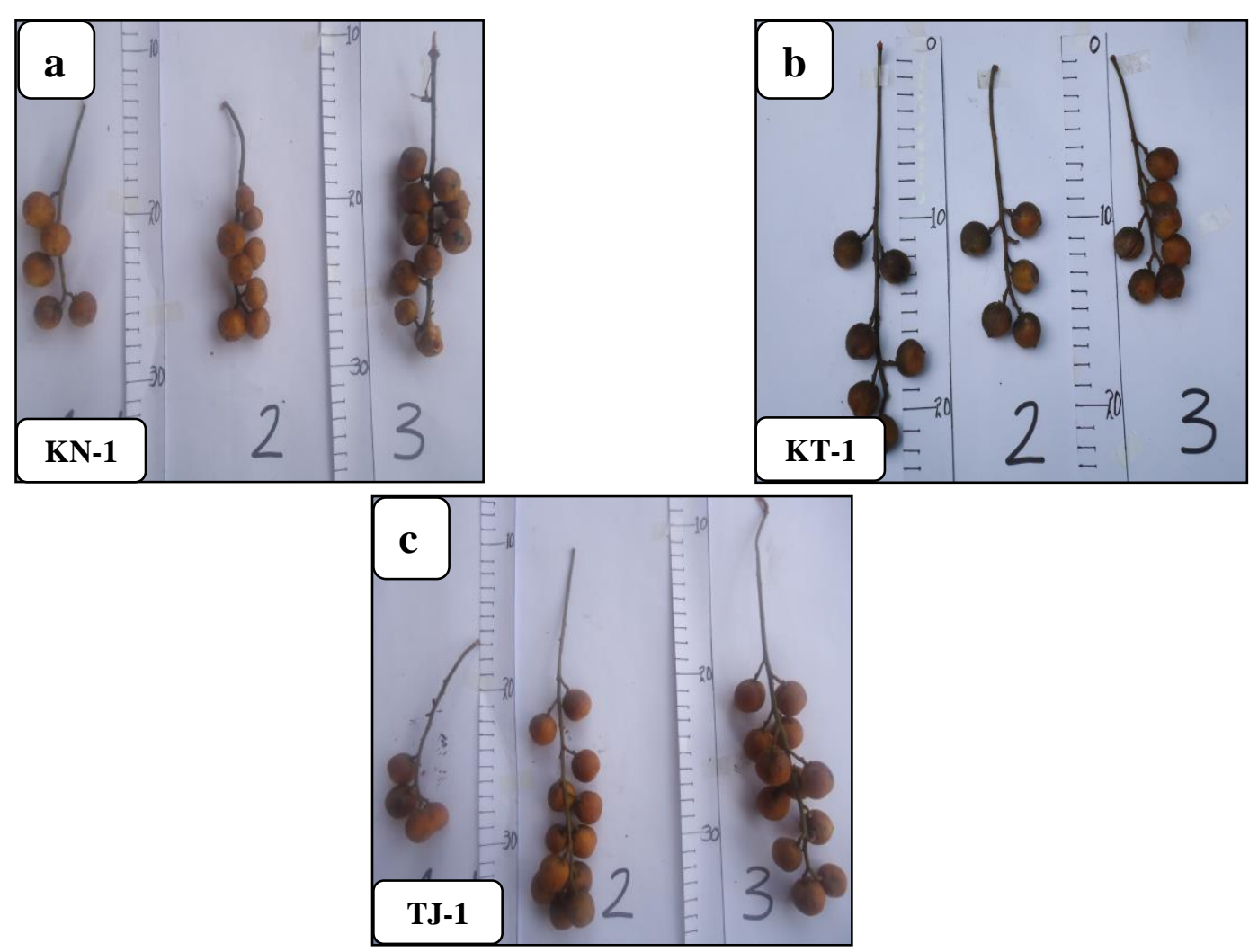

Gambar 8. Warna kulit buah (a. orange tua, b. orange kehitaman, c. orange muda) 


\subsubsection{Morfologi Biji}

Biji merupakan organ generatif dari suatu tanaman tingkat tinggi yang nantinya dapat dimanaatkan untuk perbanyakan tanaman tersebut. Berdasarkan hasil pengamatan yang dilakukan terhadap morfologi biji sijontiak menunjukkan adanya perbedaan panjang biji, lebar biji, dan bentuk biji. Data morfologi sijontiak masing-masing aksesi dapat dilihat pada lampiran 12. dan keterangan mengenai kode aksesi tanaman dapat dilihat pada Lampiran 15.

Berdasarkan hasil pengamatan terhadap morfologis biji tanaman sijontiak di Kabupaten Lima Puluh Kota menunjukan adanya variasi ukuran biji. Panjang biji sijontiak pada masing-masing aksesi berkisar antara 7,3-10 mm, lebar biji sijontiak berkisar antara $7-9,7 \mathrm{~mm}$, berat 100 biji berkisar antara 3-9 gram, jumlah biji satu buah berkisar antara 3-4 buah, bentuk biji secara umum adalah ovoid dengan warna biji adalah putih. Penampilan biji yang terpanjang, terpendek, terlebar, dan terkecil dapat dilihat pada Gambar 9.
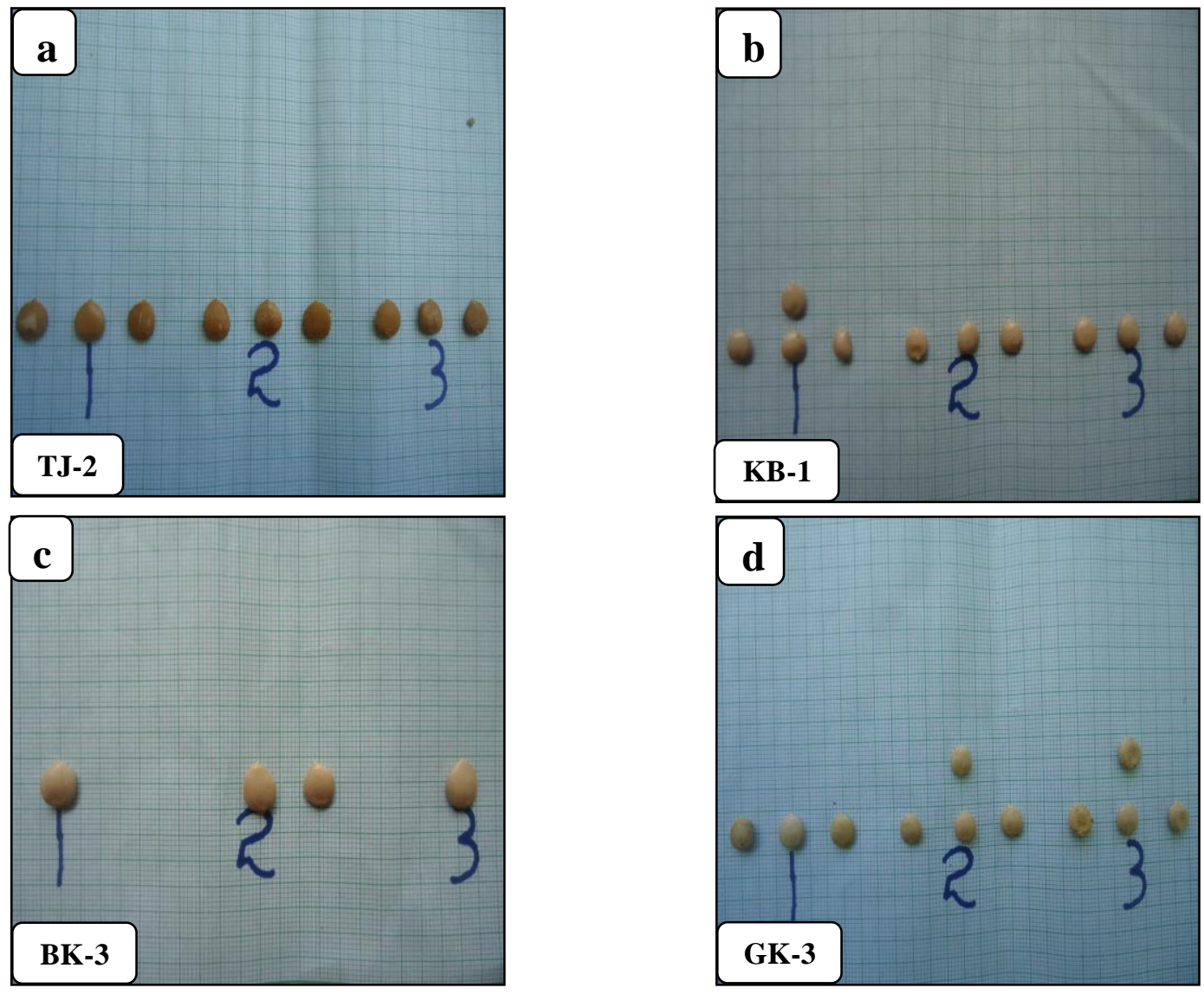

Gambar 9. (a. Panjang biji terpanjang, b. Panjang biji terpendek, c. biji terlebar,d.biji tekecil) 


\subsubsection{Morfologi Bunga}

Pengamatan terhadap karakter bunga tanaman sijontiak tidak bisa dilakukan pada semua yang diamati. Hanya pada satu tanaman yaitu pada aksesi PB-2, ini disebabkan karena pada saat melakukan pengamatan, tanaman sijontiak tidak dalam masa berbunga, sebagian tanaman sudah mulai berbuah, sebagian lagi sedang menunggu berbunga untuk musim berikutnya. Pada aksesi PB-2 bunga sijontiak memiliki panjang tangkai bunga $15 \mathrm{~cm}$, bentuk bunga seperti mangkuk, mahkota bunga berwarna kuning, benang sari berwarna kuning. Penampilan morfologi bunga dapat dilihat pada Gambar 10

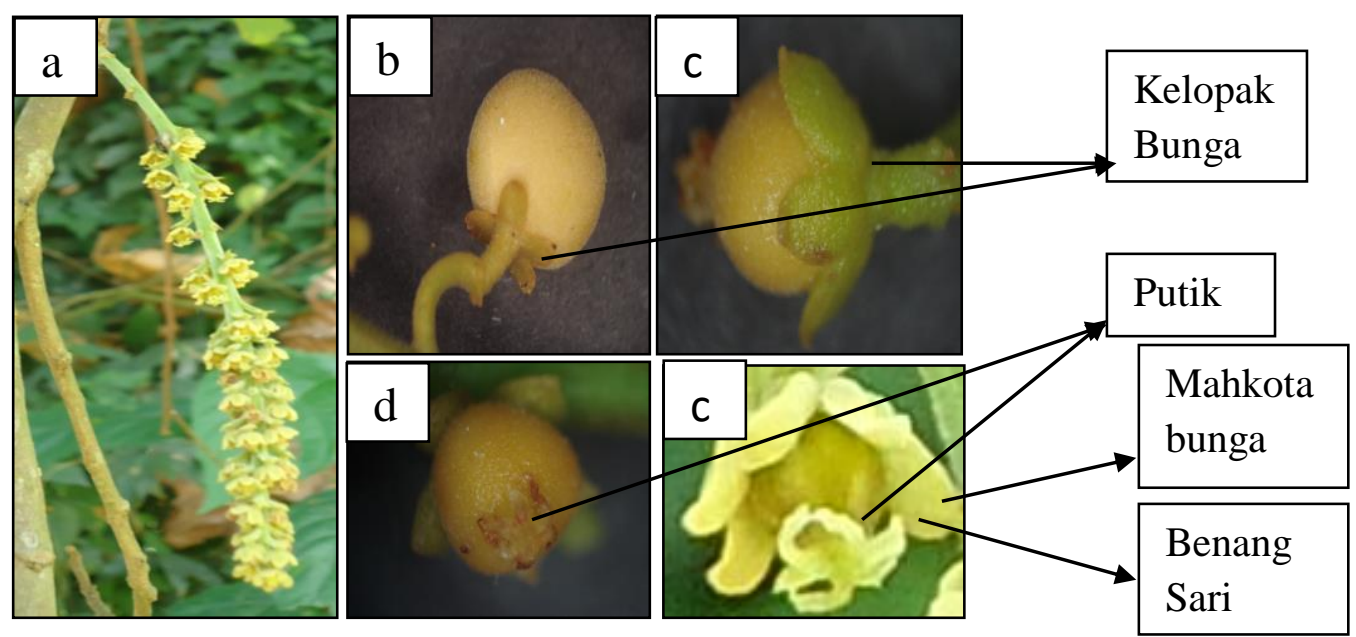

Gambar 10. Morfologi bunga sijontiak (a. Bunga sijontiak, b. Kelopak bunga, $c$ Mahkota bunga dan Benang Sari, d. Putik.

\subsection{Analisis Kadar Gula Sijontiak}

Hasil analisa kadar gula menunjukan bahwa sijontiak memiliki kadar gula yang secara umum sangat manis dimana kadar gula terendah terdapat pada aksesi GK-3 dengan persentase kadar gula 18\% dan kadar gula tertinggi terdapat pada aksesi TJ-2 sebesar 24,25\%. Umumnya sijontiak yang terdapat pada Kabupaten Lima Puluh Kota memiliki rasa daging buah yang sangat manis disertai sedikit rasa asam. Hal ini mungkin disebabkan karena kandungan kadar gulanya yang sangat tinggi. Hasil analisis kadar gula dapat dilihat pada (Lampiran 14)

Menurut Lakitan (1996), selama proses perkembangan buah berbagai perubahan kimia dan anatomi berlangsung. Tingginya kadar gula sijontiak 
disebabkan oleh faktor lingkungan terutama suhu. Perbedaan suhu yang tegas mengakibatkan karbohidrat yang disintesis pada siang hari terakumulasi sempurna untuk tanaman. Prajnanta (1998) menyatakan bahwa rasa manis tanaman akan tercapai apabila selisih antara suhu siang dan malam tegas. Suhu yang tinggi pada siang hari akan meningkat laju respirasi sehingga cadangan makanan yang tersimpan dalam buah tetap tinggi. Timbunan cadangan makanan inilah yang menjadikan buah lebih manis.

\subsection{Hasil Pengisian Kuisioner dan Wawancara dengan Pemilik Sijontiak}

Wawancara yang dilakukan dengan pemilik sijontiak di Kecamatan Guguak, umumnya pemilik tanaman tersebut menanam sijontiak dengan menggunakan biji yang berasal dari daerah setempat dan tak seorangpun pemilik yang menanam dengan menggunakan setek, sambung ataupun okulasi, umur dari tanaman ini > 50 tahun dengan rasa buah yang manis dengan sedikit asam. Teknik budidaya yang baik dan benar juga belum pernah dilakukan terhadap tanaman sijontiak seperti penyiangan, pemangkasan dan pemupukan, serta pengendalian terhadap hama dan penyakit, kalaupun ada yang melakukan pemupukan hanya menggunakan pupuk kandang kotoran sapi, karena mereka beralasan tanaman sijontiak merupakan tanaman liar yang tumbuh di hutan tanpa pemeliharaan yang khusus pun akan tumbuh dan menghasilkan buah yang dapat mereka konsumsi. Rata-rata pemilik sijontiak menanam sijontiak dengan alasan untuk dikonsumsi, jika hasil berlebih maka akan dijual.

Penyebaran sijontiak di daerah ini tidak merata, secara umum sijontiak banyak dijumpai di pekarangan rumah dan tumbuh secara liar. Umumnya rasa daging buahnya manis dengan sedikit asam, berdasarkan habitat dan ketinggiannya tanaman ini memiliki penyebaran yang cukup luas. Sijontiak dapat dapat tumbuh pada daerah terbuka, baik di hutan maupun diluar hutan, pinggiran hutan, padang rumput dan sepanjang jalan. Hal ini disebabbkan karena belum dilakukannya tekhnik budidaya sijontiak oleh masyarakat. Umur dari tanaman sijontiak ini kebanyakan pemilik kurang mengetahui berapa pastinya umur tanaman ini. 
Pada survei yang dilakukan di Kabupaten Lima Puluh Kota hanya sebagian kecil pemilik sijontiak yang mengeluh tentang hama yang menyerang tanaman sijontiak, seperti penggerek batang dan buah, tupai, dan kera. Pengendalian yang dilakukan petani berupa pengendalian manual untuk mengusir hama seperti ditembak dengan senapan angin.

Dari hasil wawancara dengan beberapa pejabat setempat, sejauh ini usaha untuk melestarikan sijontiak belum ada, karena mereka lebih memprioritaskan penanaman tanaman lain dari pada tanaman sijontiak dengan alasan lebih menjanjikan. Demikian juga untuk rencana pembukaan lahan penanaman sijontiak dalam skala luas belum ada. Pemanenan buah yang dilakukan dengan memanjat pohon sijontiak atau diambil dari bawah pohon dengan penggalan kayu. Hasil pengisian kuisioner dan wawancara dengan pemilik sijontiak yang diamati terdapat pada Lampiran 13 dan dokumentasi dengan pemilik sijontiak dapat dilihat pada Lampiran 16.

\subsection{Analisis Kemiripan}

Analisis kemiripan digunakan untuk menentukan jauh dekatnya hubungan kemiripan antara takson tanaman dengan menggunakan sifat-sifat morfologis dari suatu tanaman. Sifat morfologis dapat digunakan untuk pengenalan dan menggambarkan kemiripan dalam jenis. Jenis-jenis yang memiliki kemiripan dekat mempunyai banyak persamaan antara satu jenis dengan lainnya (Davis and Heywood tahun 1973 cit Yuniarti (2011).

Jarak taksonomi merupakan angka-angka koefisien yang secara kuantitatif menggambarkan tingkat kemiripan diantara sampel yang dibandingkan. Semakin besar nilai angka persentase kemiripan, maka semakin besar pula tingkat kemiripan diantara tanaman yang dibandingkan. Sebaliknya semakin kecil pesentase kemiripan, maka semakin kecil pula tingkat kemiripan tanaman dan semakin besar tingkat ketidakmiripan diantara tanaman yang dibandingkan.

Untuk melihat pola hubungan kemiripan tanaman sijontak yang diamati dilakukan analisis kemiripan berdasarkan 35 karakter morfologis terhadap 63 aksesi tanaman sijontiak di Kabupaten Lima Puluh Kota. Hasil analisis kemiripan 
hubungan antar 63 aksesi disajikan dalam bentuk dendogram pada Gambar 11 dan keterangan mengenai kode aksesi tanaman dapat dilihat pada Lampiran 15.

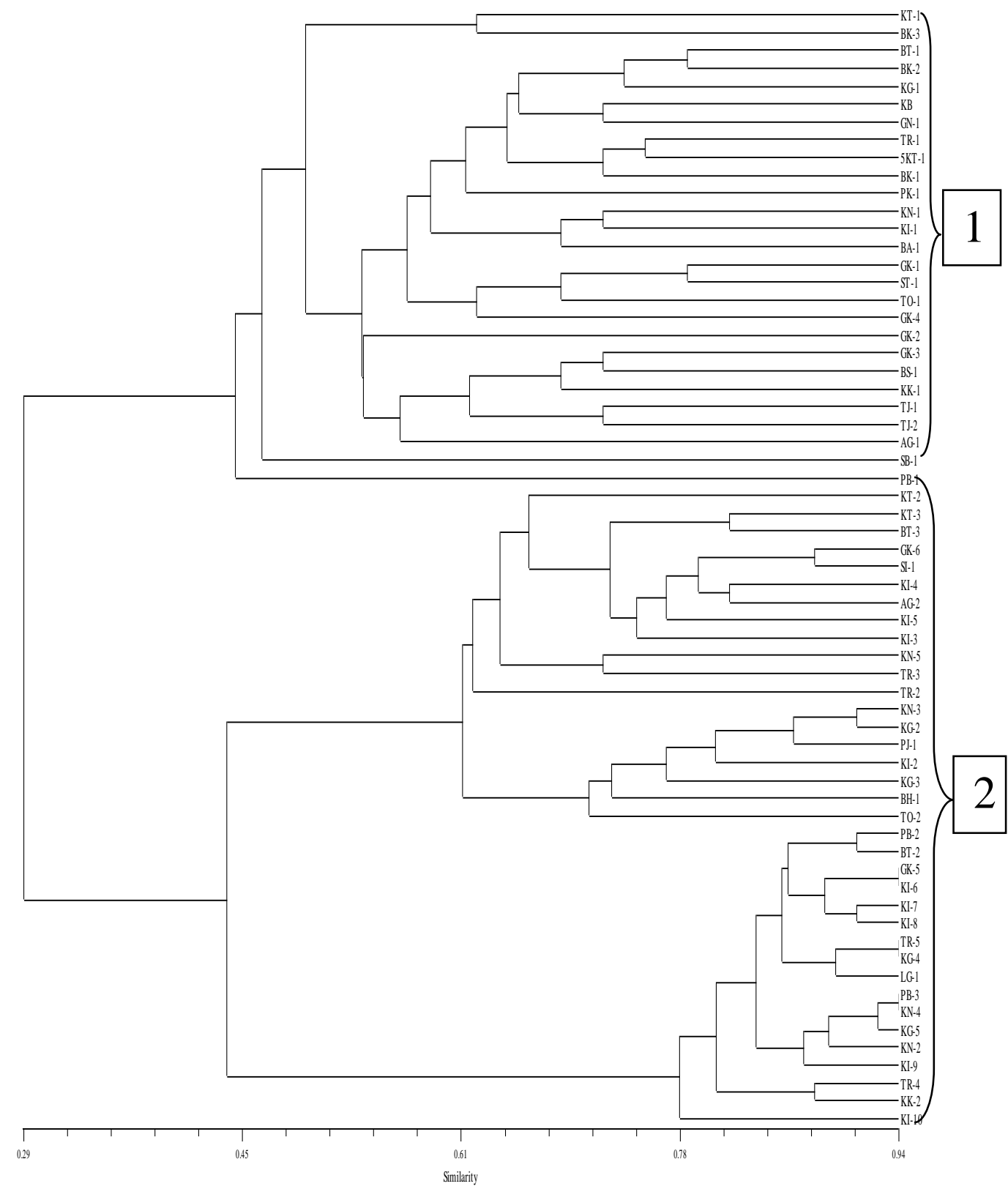

Gambar 11. Dendogram 63 aksesi tanaman sijontiak di Kabupaten Lima Puluh Kota.

Berdasarkan Gambar 11 dapat dilihat hubungan kemiripan morfologi antara aksesi tanaman sijontiak. Aksesi pada populasi yang diamati menyebar pada jarak taksonomi 29\% (terjadi variasi sebesar 65\%) dengan hubungan kemiripan yang bervariasi, tidak ditentukan oleh lokasi tempat tumbuhnya. 
Kebanyakan aksesi berada pada jarak taksonomi 61\% (terjadi variasi sebesar $33 \%$ ) yang menandakan bahwa tingkat kemiripan tanaman sijontiak di daerah cukup tinggi, sementara tingkat ketidakmiripan tertinggi terdapat pada jarak taksonomi $29 \%$ yang membagi dendogram menjadi dua kelompok besar.

Pada klasifikasi ini terdapat penggabungan jenis tanaman sijontak yang telah di inventarisasi di Kabupaten Lima Puluh Kota mulai dari kelompok kecil hingga menjadi kelompok yang besar dan akhirnya membentuk satu kelompok. Berdasarkan analisis kekerabatan terdapat 2 kelompok besar dimana satu kelompok terdiri dari kelompok-kelompok kecil yang bergabung menjadi satu kelompok. Kelompok 1 terdiri dari 27 aksesi yaitu; KT-1, BK-3, BT-1, BK-2, KG-1, KB-1, GN-1,TR-1,5KT-1, BK-1, PK-1, KN-1, KI-1, BA-1, GK-1, ST-1, TO-1, GK-4, GK-2, GK-3, BS-1, KK-1, TJ-1, TJ-2, AG-1, SB-1, PB-1 Sedangkan kelompok 2 terdiri dari 36 aksesi yaitu: KT-2, KT-3,BT-3, GK-6, SI-1, KI-4, AG2, KI-5, KI-3, KN-5, TR3, TR-2, KN-3, KG-2, PJ-1, KI-2, KG-3, BH-1, TO-2, PB-2, BT-2, GK-5, KI-6, KI-7, KI-8, TR-5, KG-4, TR-5, KG-4, LG-1, PB-3, KN4, KG-5, KN-2, KI-9, TR-4, KK-2, dan KI-10

Pada kelompok 1 yang paling jauh tingkat kemiripannya yaitu PB-1 dengan KT-1 dengan tingkat kemiripannya 45\%. Pada kelompok 2 yang paling jauh tingkat kemiripannya yaitu TR-2 dengan KT-2 dengan tingkat kemiripannya 64\%. Keanekaragaman antara aksesi ini tergolong cukup tinggi, hal ini sesuai dengan yang dikatakan Idris dan Lin (2002) yaitu keanekaragaman hayati salah satu spesies tanaman dapat dilihat dari hubungan kemiripan antar genotip dalam spesies tersebut. Hubungan kemiripan yang jauh mengindikasikan bahwa keanekaragaman hayati dalam spesies tersebut masih tinggi. Pada kelompok 1 yang paling dekat kekerabatanya adalah BT-1 dengan BK-2 dan GK-1 dengan ST1 dengan tingkat kemiripan yaitu 78\%. Pada kelompok 2 yang paling dekat tingkat kemiripannnya yaitu pada aksesi GK-5 dengan KI-6, TR-5 dengan KG-4, PB-3 dengan KN-4 dengan tingkat kemiripan yaitu 94\%.

Tingkat perbedaan kemiripan dan ketidakmiripan ini disebabkan adanya perbedaan karakter morfologis antar aksesi pada kelompok pertama dan kelompok kedua, perbedaan itu baik secara kualitatif maupun kuantitatif. Karakter-karakter kualitatif yang menyebabkan perbedaan tersebut seperti bentuk tajuk, bentuk dan 
warna daun, buah dan biji sedangkan dari segi karakter kuantitatif berupa tinggi tanaman, ukuran panjang dan lebar daun, bunga, buah dan biji. Berdasarkan dendogram ini kita juga dapat menyimpulkan bahwa tempat tumbuh dari suatu tanaman tidak mempengaruhi tingkat kemiripan dengan tanaman lain pada satu daerah yang sama.

Perbedaan karakter morfologi antar tanaman sijontiak juga dipengaruhi oleh genetik dan lingkungan. Tanaman membutuhkan keadaan lingkungan tertentu yaitu keadaan lingkungan yang optimum untuk mengekspresikan program genetiknya secara penuh (Sitompul dan Guritno, 1995).

a. Data kualitatif

Untuk melihat pola hubungan kemiripan tanaman sijontiak yang diamati dilakukan analisis kemiripan berdasarkan 22 karakter morfologi data kualitatif (bentuk tajuk, percabangan tanaman, arah tumbuh batang, permukaan batang, warna batang, bentuk penampamng melintang batang, ujung daun, pangkal daun, warna daun, permukaan daun, bentuk helaian daun, tulang daun, tepi daun, warna kulit buah, warna daging buah, rasa daging buah, bentuk buah, bentuk ujung buah, bentuk pangkal buah, pemasakan buah, warna biji, dan bentuk biji) terhadap 63 aksesi tanaman sijontiak di Kabupaten Lima Puluh Kota. Hasil analisis kemiripan antar 63 aksesi disajikan dalam bentuk dendogram pada Gambar 12 dan keterangan mengenai kode aksesi tanaman dapat dilihat pada Lampiran 15.

Berdasarkan dendogram kualitatif pada Gambar 12 menunjukan bahwa hubungan kemiripan antar aksesi memperlihatkan kemiripan sebesar 31\% (terjadi variasi sebesar 64\%) Kebanyakan aksesi berada pada jarak taksonomi 63\% yang menandakan tingkat kemiripan cukup tinggi, sementara tingkat ketidak miripan tertinggi berada pada jarak taksonomi $31 \%$ yang membagi dendogram menjadi 2 kelompok. Kelompok pertama terdiri dari 27 aksesi yaitu; (KT-1, KB-1, GN-1, GK-1, ST-1, TO-1, GK-4, BT-1, TR-1, BK-2, KG-1, AG-1, BK-1, 5KT-1, SB-1, PK-1, KN-1, BA-1, KI-1, PB-1, GK-2, GK-3, BS-1, TJ-1, KK-1, TJ-2, BK-3). Sedangkan kelompok kedua terdiri dari 36 aksesi (KT-2, TO-2, KN-3, PJ-1, KG2, KI-2, KG-3, KN-5, BH-1, KT-3, AG-2, GK-6, SI-1, KI-4, KI-3, BT-3, TR 3,TR-2, KI-5, PB-2, KI-8, KI-7, BT-2, GK-5, KI-6, PB-3, KN-4, KG-5, KN-2, KI-9, TR-5, KG-4, LG-1, TR-4, KK-2, KI-10). 
Hubungan kemiripan terdekat terdapat pada kelompok pertama terjadi pada aksesi TR-1 dengan BK-2 pada tingkat kemiripan $88 \%$ sedangkan pada kelompok 2 hubungan kemiripan terdekat terdapat pada aksesi GK-5 dengan KI-6, GK-6 dengan SI-1, PB-3 dengan KN-4 dan KG-5, dan TR-5 dengan KG-4 pada tingkat kemiripan 95\%. Hubungan kemiripan terjauh pada kelompok pertama terjadi pada aksesi PK-1 dengan Bt-1 pada tingkat kemiripan 62\% sedangkan pada kelompok kedua hubungan kemiripan terjauh terjadi pada aksesi $\mathrm{BH}-1$ dengan KT-2 pada tingkat kemiripan 58\%.

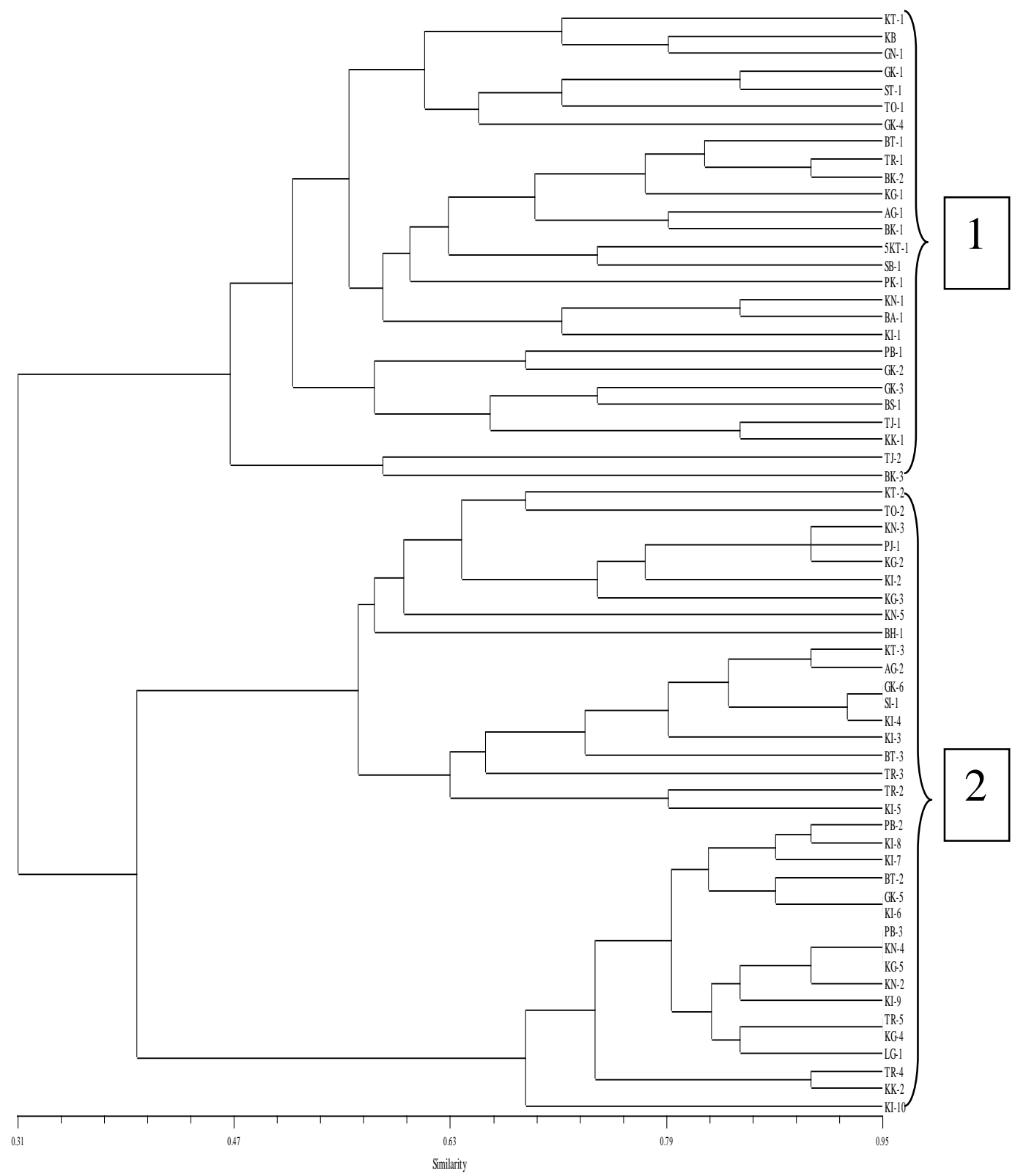

Gambar 12. Dendogram data kualitatif kemiripan 63 aksesi tanaman sijontiak 


\section{b. Data kuantitatif}

Untuk melihat pola hubungan kekerabatan tanaman sijontiak yang diamati dilakukan analisis kemiripan berdasarkan13 karakter morfologi data kuantitatif (diamater batang, panjang daun, lebar daun, panjang tangkai daun, panjang tangkai utama daun, diameter buah, ketebalan daging buah, berat buah, jumlah buah peruntaian, panjang biji, lebar biji, berat seratus biji, jumlah biji satu buah) terhadap 63 aksesi tanaman sijontiak di Kabupaten Lima Puluh Kota. Hasil analisis kemiripan antar 63 aksesi disajikan dalam bentuk dendogram pada Gambar 13 dan keterangan mengenai kode aksesi tanaman dapat dilihat pada Lampiran 15.

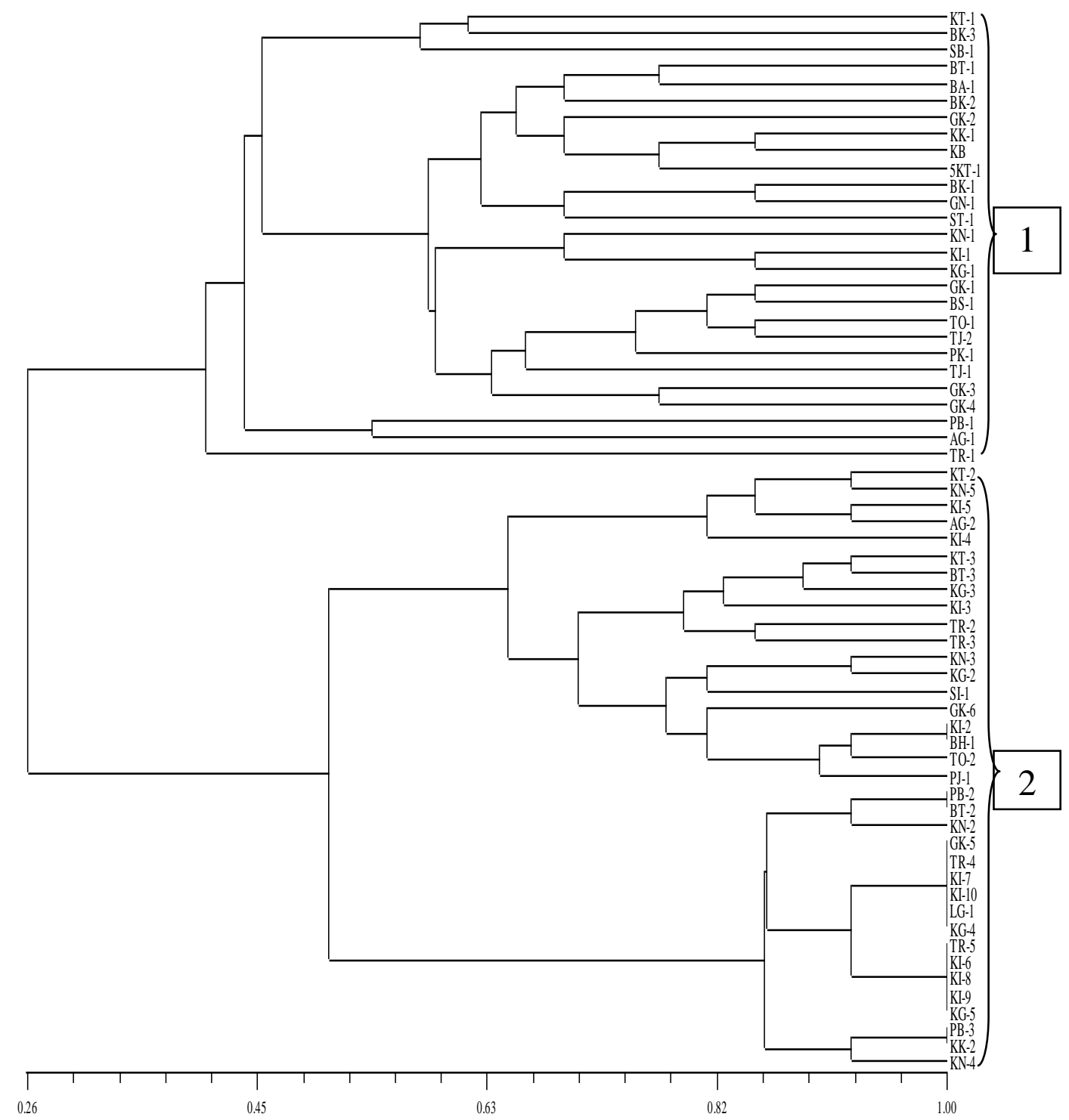

Gambar 13. Dendogram data kuantitatif kemiripan 63 aksesi tanaman sijontiak 
Berdasarkan dendogram kuantitatif pada Gambar 13 menunjukan bahwa hubungan kemiripan antar aksesi memperlihatkan kemiripan sebesar 26\% (terjadi variasi sebesar 64\%) Kebanyakan aksesi berada pada jarak taksonomi 63\% yang menandakan tingkat kemiripan cukup tinggi, sementara tingkat ketidak miripan tertinggi berada pada jarak taksonomi $26 \%$ yang membagi dendogram menjadi 2 kelompok. Kelompok pertama terdiri dari 27 aksesi yaitu; (KT-1, BK-3, SB-1, BT-1, BA-1, BK-2, GK-2, KK-1, KB-1, 5KT-1, BK-1, GN-1, SI-1, KN-1, KI-1, KG-1, GK-1, BS-1, TO-1, TJ-2, PK-1, TJ-1, GK-3, GK-4, PB-1, AG-1, TR-1). Sedangkan kelompok kedua terdiri dari 36 aksesi yaitu; (KT-2, KN-5, KI-5, AG2, KI-4, KT-3, BT-3, KG-3, KI-3, TR-2, TR-3, KN-3, KG-2, SI-1, GK-6, KT-2, BH-1, TO-2, PJ-1, PB-2, BT-2, KN-2, GK-5, TR-4, KI-7, KI-10, LG-1, KG-4, TR-5, KI-6, KI-8, KI-9, KG-5, PB-3, KK-2, KN-4).

Hubungan kemiripan terdekat terdapat pada kelompok pertama terjadi pada aksesi KK-1 dengan KB-1, BK-1 dengan KN-1, KI-1 dengan KG-1, GK-1 dengan BS-1, dan TJ-2 dengan PK-1 pada tingkat kemiripan $85 \%$ sedangkan pada kelompok 2 hubungan kemiripan terdekat terdapat pada aksesi KI-2 dengan BH-1, PB-2 dengan BT-2, GK-5, TR-4, KI-7, KI-10, LG-1, dengan KG-4, KI-6, KI-8, KI-9 dengan KG-5, dan PB-3 dengan KK-2 pada tingkat kemiripan $100 \%$. Hubungan kemiripan terjauh pada kelompok pertama terjadi pada aksesi TR-1 dengan KT-1 pada tingkat kemiripan $41 \%$ sedangkan pada kelompok kedua hubungan kemiripan terjauh terjadi pada aksesi KI-4 dengan KT-2, SI-1 dengan KN-3, dan GK-6 dengan PJ-1 pada tingkat kemiripan 82\%

Tingkat perbedaan kemiripan dan ketidakmiripan ini disebabkan adanya perbedaan karakter morfologi secara kuantitatif antara aksesi kelompok pertama dan kedua. Karakter kuantitatif yang menyebabkan perbedaan tersebut seperti diamater batang, panjang daun, lebar daun, panjang tangkai daun, panjang tangkai utama daun, diameter buah, ketebalan daging buah, berat buah, jumlah buah peruntaian, panjang biji, lebar biji, berat seratus biji, dan jumlah biji satu buah.

\subsection{Variabilitas Fenotipik}

Setelah dilakukan penelitian dan pencatatan data berdasarkan pengamatan dilapangan, secara keseluruhan memiliki nilai variabilitas yang luas. Hal ini disebabkan pengaruh genetik lebih dominan dari pada pengaruh lingkungan tanaman itu sendiri. Data tersebut diolah dan didapatkan data fenotipik tanaman. Data variabilitas fenotipik tanaman sijontiak disajikan dalam Tabel 2. 
Tabel 2. Data variabilitas fenotipik tanaman sijontiak

\begin{tabular}{|c|c|c|c|c|}
\hline No & Variabel Pengamatan & $\begin{array}{l}\text { Ragam } \\
\text { Fenotipik } \\
\left(\sigma^{2} f\right)\end{array}$ & $\begin{array}{c}\text { Standar } \\
\text { Deviasi } \\
\text { Fenotipik }\end{array}$ & $\begin{array}{c}\text { Variabilitas } \\
\text { Fenotipik }\end{array}$ \\
\hline 1 & Tinggi Tanaman & 13.8 & 3.71 & Luas \\
\hline 2 & Permukaan Batang & 2424 & 49.23 & Luas \\
\hline 3 & Arah Tumbuh Batang & 577.33 & 7.57 & Luas \\
\hline 4 & Bentuk Tajuk & 614.9 & 24.79 & Luas \\
\hline 5 & Tipe Percabangan & 422.67 & 20.56 & Luas \\
\hline 6 & Bentuk Penampang Batang & 992.25 & 31.5 & Luas \\
\hline 7 & Warna batang & 1417.2 & 37.65 & Luas \\
\hline 8 & Diamater Batang & 2171.28 & 46.6 & Luas \\
\hline 9 & Ujung Daun & 913.07 & 30.21 & Luas \\
\hline 10 & Tepi Helaian Daun & 567 & 23.81 & Luas \\
\hline 11 & Permukaan Daun & 1753 & 41.87 & Luas \\
\hline 12 & Panjang Helaian Daun & 3.54 & 1.88 & Sempit \\
\hline 13 & Tulang Daun & 992.25 & 31.5 & Luas \\
\hline 14 & Bentuk Pangkal Daun & 5429.14 & 73.68 & Luas \\
\hline 15 & Bentuk Helaian Daun & 4258.27 & 65.26 & Luas \\
\hline 16 & Bentuk Ujung Daun & 103.09 & 30.22 & Luas \\
\hline 17 & Warna daun & 25394.6 & 65.01 & Luas \\
\hline 18 & lebar helaian daun & 0.9 & 0.95 & Sempit \\
\hline 19 & panjang tangkai daun & 0.71 & 0.85 & Sempit \\
\hline 20 & Panjang tangkai utama buah & 61.25 & 5.85 & Luas \\
\hline 21 & panjang tangkai buah & 0.05 & 0.22 & Sempit \\
\hline 22 & Diameter buah & 0.12 & 0.35 & Sempit \\
\hline 23 & Ketebalan daging buah & 0.41 & 0.64 & Sempit \\
\hline 24 & Berat Satu Buah & 0.6 & 0.74 & Sempit \\
\hline 25 & Jumlah buah peruntaian & 17.29 & 4.16 & Luas \\
\hline 26 & warna kulit buah & 1173.75 & 34.26 & Luas \\
\hline 27 & warna daging buah & 1300.67 & 36.06 & Luas \\
\hline 28 & Bentuk buah & 927.07 & 30.45 & Luas \\
\hline 29 & bentuk ujung buah & 1084.97 & 32.94 & Luas \\
\hline 30 & Bentuk Pangkal buah & 1762.29 & 41.98 & Luas \\
\hline 31 & panjang biji & 0.48 & 0.69 & Sempit \\
\hline 32 & lebar biji & 0.6 & 0.77 & Sempit \\
\hline 33 & berat 100 biii & 39.75 & 1.26 & Luas \\
\hline 34 & jumlah biji perbuah & 0.26 & 0.51 & Sempit \\
\hline 35 & warna biji & 182.25 & 13.5 & Luas \\
\hline 36 & betuk biji & 1944 & 44.09 & Luas \\
\hline
\end{tabular}


Berdasarkan tabel diatas ada beberapa variable pengamatan yang memiliki fenotipik luas dan fenotipik sempit. Variabilitas fenotipik yang luas terdapat pada pengamatan tinggi tanaman, permukaan batang, arah tumbuh batang, bentuk tajuk, tipe percabangan, bentuk penampang batang, warna batang, diameter batang, ujung daun, tepi helaian daun, permukaan daun, tulang daun, bentuk pangkal daun, bentuk ujung daun, bentuk helaian daun, warna daun, panjang tangkai utama buah, jumlah buah peruntaian, warna kulit buah, warna daging buah, bentuk ujung buah, bentuk pangkal buah, bentuk buah, berat 100 biji, warna biji dan bentuk biji. Selain dari pengamatan yang telah disebutkan, memiliki variabilitas fenotipik yang sempit. Hal ini dipengaruhi oleh faktor lingkungan atau faktor genetik tanaman itu sendiri, karena fenotip merupakan interaksi antara genotip dan lingkungan. Apabila nilai variabilitasnya luas, berarti faktor genetik tanaman tersebut lebih dominan peranannya dari pada faktor lingkungan ataupun fakor lainnya, begitu juga sebaliknya (Poespapodarsono, 1988). Senada dengan pernyataan ini, Swasti (2006) juga menyatakan bahwa keragaman (variabilitas) dapat disebabkan karena: 1) keragaman genetik, 2) keragaman lingkungan. Kriteria penilaian luas atau sempit variabilitas karakter yang diamati diketahui berdasarkan kriteria Drajat (1987), sebagai berikut:

$\sigma^{2} f>2 \times$ S.D berarti variabilitas fenotipik luas

$\sigma^{2} f<2 \times$ S.D berarti variabilitas fenotipik sempit

Menurut Poespadarsono (1988), pengaruh lingkungan dan genotip pada nilai fenotip sangat sulit dilihat perananya secara langsung. Padahal pemulia ingin mengetahui sampai seberapa jauh peranan genotip, karena genotip sangat penting dalam menentukan nilai pemuliaan tanaman.

Varaiasi fenotipik yang luas sangat menguntungkan bagi pemuliaan tanaman, karena para pemulia bekerja dengan keragaman-keragaman, baik secara konvensional maupun non konvensional

Besar kecilnya suatu nilai pemuliaan erat hubungannya dengan kemampuan tanaman untuk memperbaiki sifat melalui seleksi tanaman pada turunan generasi berikutnya. Untuk mengetahui peran genotip dan lingkungan dapat dihitung melalui keragaman fenotip pada suatu generasi (Poespodarsono, 1988). 
Keragaman fenotipik merupakan jumlah dari keragaman yang disebabkan oleh genotip dan lingkungan. Hal ini ada kaitanya dengan nilai heritabilitas. Nilai heritabilitas berkisar antara 0-1, heritabilitas dengan nilai 0 berarti keragaman fenotip hanya disebabkan oleh lingkungan, sedangkan nilai 1 berarti keragaman fenotip hanya disebabkan oleh genotip saja. Semakin mendekati 1 menyatakan nilai heritabiltasnya makin tinggi atau sebaliknya (Poespodarsono, 1988) 


\title{
V. KESIMPULAN DAN SARAN
}

\begin{abstract}
5.1 Kesimpulan
Berdasarkan penelitian yang telah dilakukan di Kecamatan Guguak, Kabupaten Lima Puluh Kota ditemukan keragaman sijontiak dengan tingkat kemiripan yang cukup tinggi. Berdasarkan hasil inventarisasi dan karakterisasi morfologi diperoleh kesimpulan sebagai berikut :

a. Berdasarkan pengamatan yang telah dilakukan, tinggi tanaman sijontiak tertinggi pada saat pengamatan terdapat pada aksesi BS-1 yaitu 35,60 m dan yang terendah pada aksesi BT-3 yaitu 15,6 m.

b. Berdasarkan morfologis tanaman sijontiak ditemukan 4 bentuk tajuk tanaman sijontiak yaitu: (1) oblong sebanyak 28\%, (2) spherical sebanyak 27\%, (3) phyramidal sebanyak 25\%, (4) elliptical sebanyak 19\% dari 63 aksesi tanaman sijontiak di Kabupaten Lima Puluh Kota. Tipe arah tumbuh batang keatas sebanyak (1) $79 \%$ (2) keluar sebanyak 21\%. Pada percabangan pohon sijontiak terdapat tiga tipe percabangan yaitu: (1) erect sebanyak 44\%, (2) intermediate sebanyak 40\%, (3) spreading sebanyak $16 \%$.

c. Berdasarkan morfologis batang ditemukan 10 macam tipe tanaman sijontiak yaitu: (1) agak kasar-coklat sebanyak 7,9\%, (2) agak kasar- coklat muda 22,22 \%, (3) kasar-abu-abu 1,59\%, (4) kasar-coklat 30,16\%, (5) kasar-coklat tua 6,35\%, (6) kasar-coklat muda 22,22\%, (7) sangat kasar-abu-abu 1,59\%, (8) sangat kasar-coklat 3,17\%, (9) sangat kasar-coklat tua 1,59\%, (10) sangat kasar-coklat muda 3,17\% dari 63 aksesi tanaman sijontiak.

d. Berdasarkan pada morfologi daun ditemukan 4 tipe bentuk daun yaitu : (1) elliptic sebanyak 71,4\%, (2) ovate $25,36 \%$, (3) obovatus 1,59\%, dan (4) oblong $1,59 \%$. Sedangkan warna daun terdiri dari tiga macam warna yaitu: (1) hijau tua sebanyak 73\%, (2) hijau 20,6\%, (3) hijau muda 6,3\%.

e. Berdasarkan morfologis buah tanaman sijontiak dimana jumlah aksesi yang buahnya masak adalah 27 aksesi ditemukan 3 bentuk buah sijontiak seperti, (1) globose sebanyak 51,9\%, (2) oblate sebanyak 44,4\%, (3) oval sebanyak $3,73 \%$, rasa daging buahya manis dengan sedikit asam.Warna daging buah yaitu: (1) orange tua sebanyak $66,7 \%,(2)$ orange sebanyak $9,5 \%,(3)$ orange
\end{abstract}


muda sebanyak $11,1 \%$. Warna kulit buah berwarna orange tua sebanyak (1) $66,7 \%,(2)$ orange kehitaman sebanyak $14,8 \%$, (3) orange sebanyak 18,5\%.

f. Berdasarkan hasil pengamatan terhadap morfologis biji menunjukan adanya variasi ukuran biji. Panjang biji sijontiak pada masing-masing aksesi berkisar antara 7,3-10 mm Lebar biji sijontiak berkisar antara 7-9,7 mm. Bentuk biji secara umum pada tanaman sijontiak adalah ovoid dengan warna biji adalah putih.

g. Berdasarkan pada morfologi bunga tidak ditemukan perbedaan karena bunga hanya ditemukan pada aksesi PB-2. Pada aksesi PB-2 bunga sijontiak memiliki karakter panjang tangkai bunga $15 \mathrm{~cm}$, bentuk bunga seperti mangkuk, mahkota bunga berwarna kuning, benang sari berwarna kuning.

h. Berdasarkan analisis kemiripan data kualitatif dan kuantitatif terdapat pada tingkat kemiripan 29\% (terjadi variasi sebesar 65\%). Berdasarkan data kualitatif pada tingkat kemiripan sebesar 31\% (terjadi variasi sebesar 64\%) dan data kuantitatif pada tingkat kemiripan sebesar 26\% (terjadi variasi sebesar $84 \%$ )

i. Nilai variabilitas luas ditemukan pada pengamatan tinggi tanaman, permukaan batang, arah tumbuh batang, bentuk tajuk, tipe percabangan, bentuk penampang batang, warna batang, diameter batang, ujung daun, tepi helaian daun, permukaan daun, tulang daun, bentuk pangkal daun, bentuk ujung daun, bentuk helaian daun, warna daun, panjang tangkai utama buah, jumlah buah peruntaian, warna kulit buah, warna daging buah, bentuk ujung buah, bentuk pangkal buah, bentuk buah, berat 100 biji, warna biji dan bentuk biji. Selain dari pengamatan yang telah disebutkan, memiliki variabilitas fenotipik yang sempit.

\subsection{Saran}

Berdasarkan penelitian yang telah dilakukan, penelitian ini hanya melihat dari segi morfologinya, oleh karena itu diharapkan untuk peneliti selanjutnya dapat melengkapi data yang belum ada dan melanjutkan penelitian ini dengan identifikasi berdasarkan pola pita DNA (molekuler) dan identifikasi berdasarkan sitologi sehingga nantinya dapat melengkapi data karakteristik tanaman sijontiak. 


\section{DAFTAR PUSTAKA}

Anonim. 2011. Kayu Jentikan. http://sites.google.com/site/dangaulubai/inspirasiflora/kayu-jentikan. (30 Oktober 2011)

Ardi. 2006. Pelestarian Plasmanutfah. Fakultas Pertanian Universitas Andalas. Padang.

Aryanti, Destrysia. 2010. Mengkomunikasikan Keanekaragaman Hayati di Indonesia. http://blog.unila.ac.id. [1 September 2012].

Badan Pusat Statistik Kabupaten Lima Puluh Kota. 2009. Kabupaten Lima Puluh Kota dalam angka 2009.

Bioverssity. 2007. Description for durian (durio zibethinus murr). Italy: Bioversity International

Drajat, A. A. 1987. Variabilitas Adaptasi Genotipe Terigu Pada Berbagai Lingkungan Tumbuh di Indonesia. Disertasi. Universitas Buletin Penelitian Kehutanan Vol. III. No. 1 (1998)

Filnasari, R. 2007. "Karakterisasi Morfologis Tanaman Pisang (Musa paradisiaca) di Kecamatan Tanjung Baru Kabupaten Lima Puluh Kota". Skripsi. Padang: UNAND

Haegens. R.M.A.P. 2000. "Taxonomy, Phylogeny, and Biogeography of Baccaurea Distichirhops, and Nothobaccaurea (Euphorbiaceae)". Blumea Suppl. 12: 216

Hanarida. I. 2007. Mengenal Plasmanutfah Tanaman Pangan. http//www. BBB Biogen.(31 Oktober 2011).

Heywood, I. 2007. Mengenal Plasma Nutfah Tanaman Pangan. Http // www Biogen.(31 Oktober 2011).

Idris, S. dan R.M. Lin. 2002. Status Report on Genetic Resources of Kuini (MangiferaodorataGriff.)in Southeast Asia. IPGRI Office for South Asia. National Agriculture Science Centre (NASC). DPS Marg, Pusa Campus, New Delhi. 21 p.

Lakitan, B. 1996. Fisiologi Pertumbuhan dan Perkembangan Tanaman. Jakarta: PT Raja Grafindo Persada.

Lembaga Ilmu Pengetahuan Indonesia (LIPI). 2007.”Keanekaragaman Jenis Buah Buahan Asli Indonesia dan Potensinya". Jurnal Biodiversitas Volume 8, Nomor 2 April 2007. Halaman: 157-167 . 
Lima Puluh Kota. 2011. "Profil Kecamatan Kabupaten Lima Puluh Kota". http://limapuluhkota.org/. (20 Desember 2011).

Mangoendidjojo, W. 2003. Dasar-Dasar Pemuliaan Tanaman. Kanisius. Yogyakarta.

Munawaroh, E. 2000. "Potensi Baccaurea spp Sebagai Penghasil Buah-Buahan dan Usaha Pelestarianhya di Kebun Raya Bogor Prosiding Seminar Sehari Cipta Puspa dan Satwa Nasional.Bogor”. Halaman: 82

Nasution, R. 2003. Tekhnik sampling. Fakultas Kesehatan Masyarakat Universitas Sumatera Utara: Medan.

Nazarudin dan Muchlisah. 1994. Buah Komersial. Penebar Swadaya. Jakarta. 172 hal.

Poespodarsono. 1988. Pengantar Ilmu Pemuliaan Tanaman. Bogor: Pusat Antar Universitas. IPB.

Prajnanta, F. 1998. Melon Pemeliharaan Secara Intensif Kiat Sukses Beragrobisnis. Jakarta: Penebar Swadaya.

Prihadi. 2011.TanamanLangka.http://arboretumunpadjatinangor.blogspot.com/201

Rusli, Y. 2002. "Penampilan beberapa varietas broccoli (Brasssica oleracea) introduksi di Padang Luar". Skripsi. Padang: Universitas Andalas.

Saputra, T. 2011. "Identifikasi dan Karakterisasi Morfologis Tanaman Durian (Durio zibethinus Murr.) di Kabupaten Lima Puluh Kota”. Skripsi. Padang: Universitas Andalas

Siregar. 2002. Peran Masyarakat Adat Kalimantan Dalam Melestarikan Plasma Nutfah Pohon Buah-Buahan. Bogor: Prosiding Seminar Sehari Cipta Puspa dan Satwa Nasional.

Sitompul, SM,. Guritno, B. 1995. Analisis Pertumbuhan Tanaman. Yogyakarta: Gadjah Mada University Press.

Steel, R. G. D and Torrie. Jh. 1995. Principles and Procedur of Statistics, magro Hill Book Co. Inc. New York.

Swasti, E. 2006. Penuntun Pengantar Pemuliaan Tanaman. Padang. Fakultas Pertanian Universitas Andalas.

Swasti, E. 2007. Pengantar Pemuliaan Tanaman. Buku Ajar. Padang. Fakultas Pertanian Universitas Andalas 
Tjiptrosoepomo, G. 2005. Morfologi Tumbuhan. Yogyakarta: Gadjah Mada University Press.

Yuanita, P. 2006. "Identifikasi dan Karakterisasi Keragaman Morfologi Kuini (Mangifera odorata Grift.) di Kabupaten Pesisir Selatan”. Skripsi. Padang: Universitas Andalas.

Yuniarti. 2011. "Inventarisasi dan Karakterisasi Morfologis Tanaman Durian (Durio zibethinus) di Kabupaten Tanah Datar". Skripsi. Padang: Universitas Andalas. 
Lampiran 1. Jadwal Kegiatan

\begin{tabular}{|c|c|c|c|c|c|c|c|c|c|c|c|c|}
\hline \multirow[b]{2}{*}{ Kegiatan } & \multicolumn{12}{|c|}{ Minggu ke } \\
\hline & 1 & 2 & 3 & 4 & 5 & 6 & 7 & 8 & 9 & 10 & 11 & 12 \\
\hline $\begin{array}{c}\text { Survey } \\
\text { Pendahuluan }\end{array}$ & & & & & & & & & & & & \\
\hline $\begin{array}{c}\text { Penempatan } \\
\text { Sampel }\end{array}$ & & & & & & & & & & & & \\
\hline 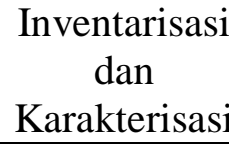 & & & & & & & & & & & & \\
\hline Analisis Data & & & & & & & & & & & & \\
\hline $\begin{array}{l}\text { Penulisan } \\
\text { skripsi }\end{array}$ & & & & & & & & & & & & \\
\hline
\end{tabular}


Lampiran 2. List Descriptor sebagai Acuan Variabel Pengamatan Morfologi

A. Tinggi Tanaman

3. rendah $<20 \mathrm{~m}$

5. sedang $20-30 \mathrm{~m}$

7. tinggi $>30 \mathrm{~m}$

B. Bentuk Kanopi/Tajuk

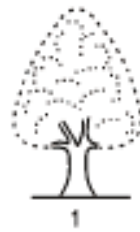

1. Pyramidal

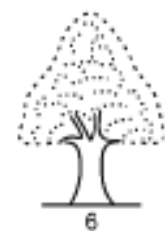

6. irregular

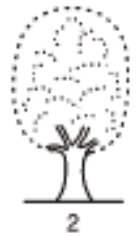

2. Oblong

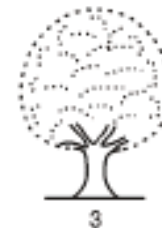

3. Spherical
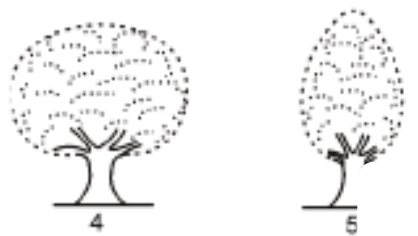

4. Semi-circular 5.Elliptıcaı

\section{Karakteristik Batang}

1) Permukaan Batang

1. Halus

2. Agak kasar

3. Kasar

4. Sangat Kasar

99. Lain-lain

2) Arah Tumbuh Batang

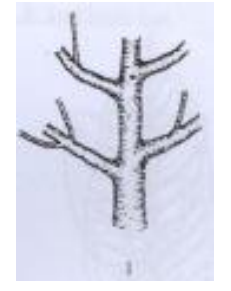

1. keatas

99. Lain-lain.

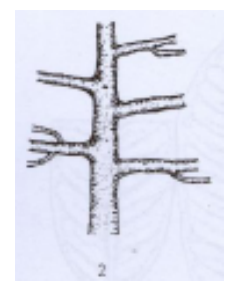

2. keluar

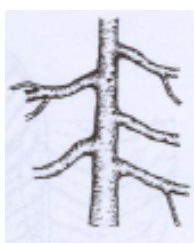

3. kebawah 
3) Tipe Percabangan

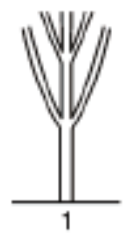

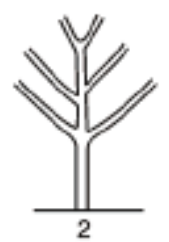

2. Intermediate

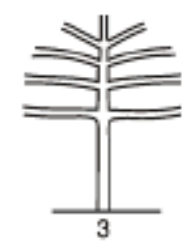

3. Spreading

\section{Erect}

99. Lain-lain

4) Bentuk Penampang melintang Batang

1. Bulat

2. Bersegi

3. Pipih

5) Warna kulit batang

1. Abu-abu

2. Coklat

3. Coklat muda

4. Coklat tua

99. Lain-lain

6) Diamater Batang

3. Kecil $<100 \mathrm{~cm}$

5. Sedang 100-200 cm

7. Besar $>200 \mathrm{~cm}$

\section{Karakteristik Daun}

1) Ujung Daun (Apex)

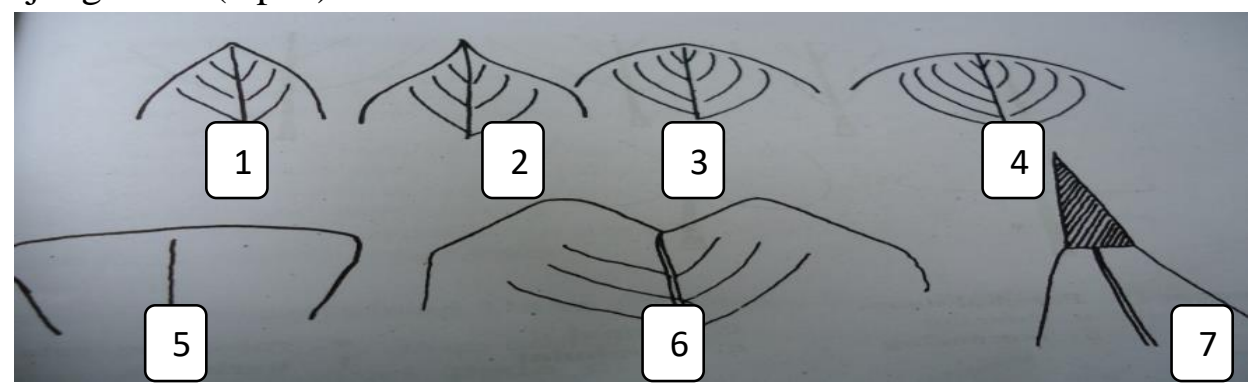

1. runcing

2. meruncing

3. tumpul

4. membulat
5. rompang

6. terbelah

7. Berduri

99. lain-lain 
2) Tepi helaian daun (Margo)

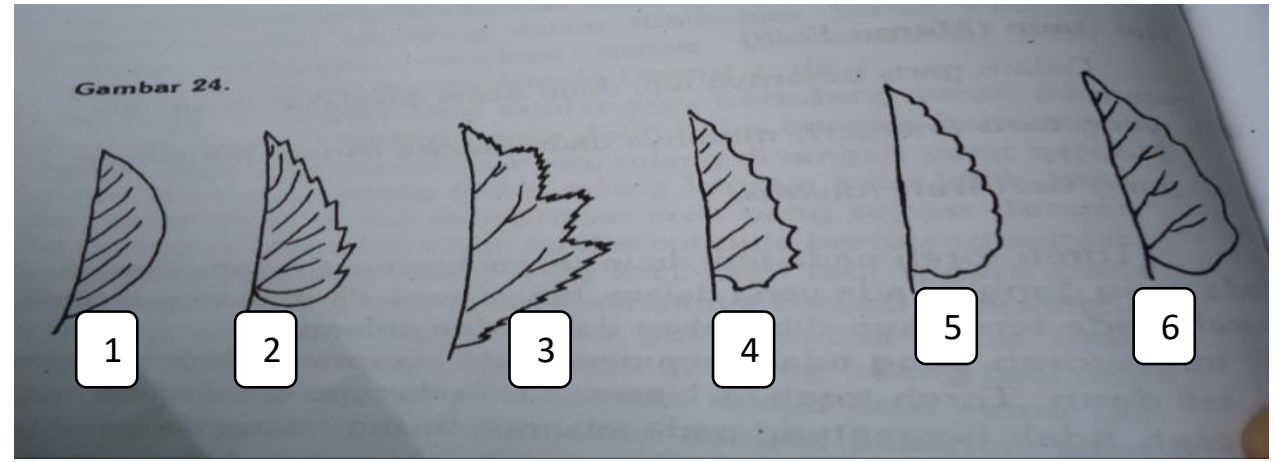

1. bertepi rata

2. bergerigi

3. bergerigi ganda

99. lain-lain

3) Permukaan Daun

1. Halus

2. Agak kasar

3. Kasar

4) Panjang helaian daun

3. Pendek $\quad(<15 \mathrm{~cm})$

5. Menengah $(15-20 \mathrm{~cm})$

7. Panjang (>20 cm)

5) Lebar helaian daun

3. Sempit $(<6 \mathrm{~cm})$

5. Sedang $(6-8 \mathrm{~cm})$

7. Lebar $(>8 \mathrm{~cm})$

6) Tulang Daun
4. bergerigi

5. beringgit

6. Berombak

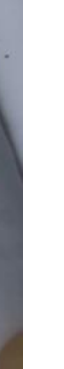


7) Panjang tangkai daun

3. Pendek (<3 cm)

5. Menegah ( $3-5 \mathrm{~cm}$ )

7. Panjang (> $5 \mathrm{~cm})$

8) Bentuk Pangkal Daun

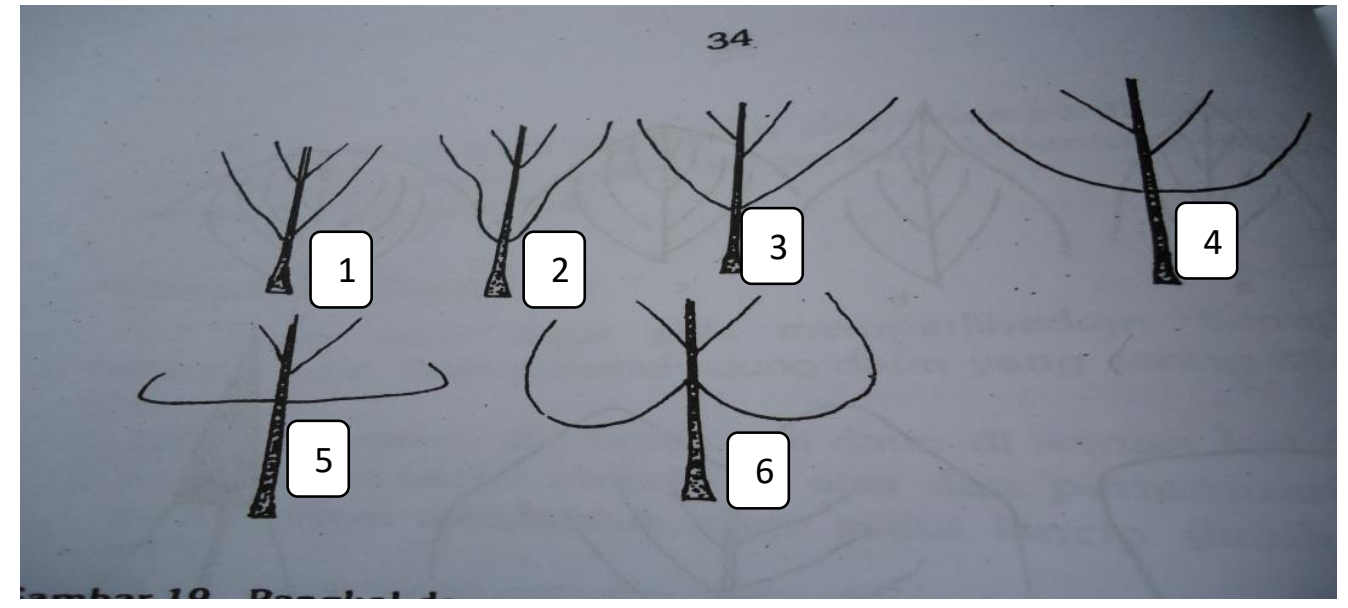

1. runcing

2. meruncing

3. tumpul

7. lain-lain

9) Bentuk helaian daun
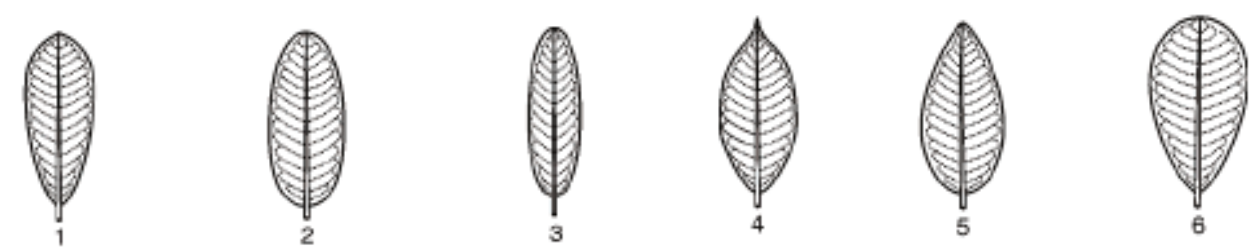

1 Obovate-lanceolat 2 Oblong 3 Linear-oblong 4 Elliptic 5 Ovate 6Obovate 7Obovatus 99. Dan lain-lain

10) Warna Daun

1. Hijau muda

2. Hijau

3. Hijau tua

99. Lain-Lain

11) Tipe Daun 


\section{E. Karakterisrik Buah}

1) Bentuk buah

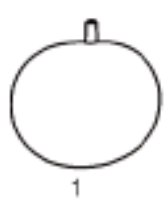

1 Oblate<smiles>C1CCCCCC1</smiles>

6 Obovoid

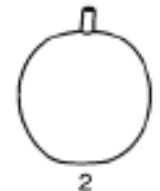

2 Globose

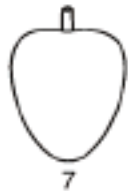

7 Ovoid

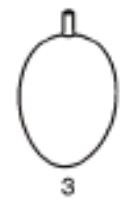

3 Oval

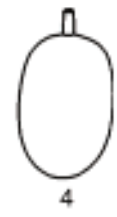

4 Oblong

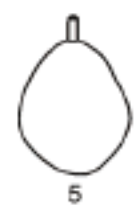

5 Elliptic

2) Pematangan buah

1 Merata

2 Tidak merata

3) Panjang tangkai utama buah

3. Pendek $(<15 \mathrm{~cm})$

5. Menengah $(15-20 \mathrm{~cm})$

7. Panjang $(>20 \mathrm{~cm})$

4) Ketebalan daging buah

3. Tipis $(<2 \mathrm{~mm})$

5. Sedang $(2-3 \mathrm{~mm})$

7. Tebal $(>3 \mathrm{~mm})$

5) Bentuk ujung buah

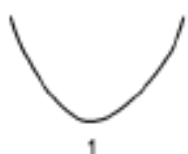

1

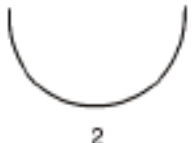

2 Convex
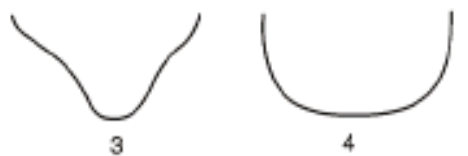

3 Mammiform 4 Truncate

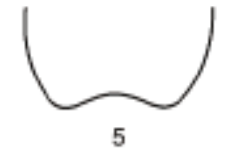

5 Depressed

99. Lain-lain 
6) Bentuk pangkal buah

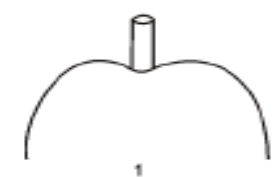

1 Depressed

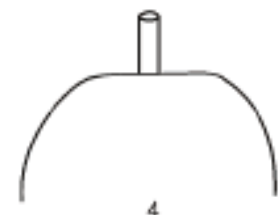

4 Truncate

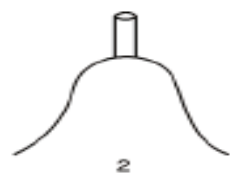

2 Necked

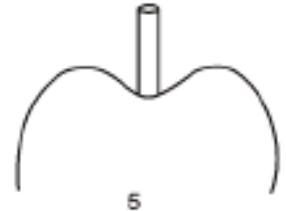

5 Concave

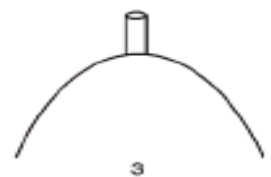

3 Convex

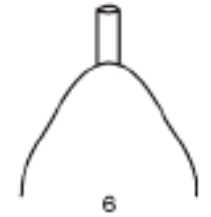

6 Acute

99. Lain-lain

7) Rasa daging

1. Asam

2. Manis dengan sedikit asam

3. Manis

8) Warna kulit buah

1. Hijau

2. Hijau muda

3. Hijau tua

4. Kuning

5. Orange

6 Orange muda

7. Orange tua

8. Orange kehitam hitaman

99. Lain-lain

9) Warna daging buah

1. Orange

2. Orange muda

3. Orange tua

4. Putih susu

99. Lain-lain 
10) Berat Satu buah (gr)
3. Ringan
$(<2$ gram $)$
5. Sedang
(2-4 gram)
7. Berat
(> 4 gram)

11) Kadar Gula Buah (\%)

1. $<10 \%=$ Asam

2. $10-15 \%=$ Agak Manis

3. $16-20 \%=$ Manis

4. $>20 \%=$ Sangat Manis

12) Jumlah Buah Peruntaian (bh)

3. Sedikit $(<10 \mathrm{bh})$

5. Sedang (10-16 bh)

7. Banyak (>16 bh)

13) Panjang tangkai buah

14) Diameter buah $(\mathrm{cm})$

3. Kecil $(<2 \mathrm{~cm})$

5. Sedang $(2-3 \mathrm{~cm})$

7. Besar $(>3 \mathrm{~cm})$

\section{F. Karakteristik Biji}

1) Panjang biji $[\mathrm{mm}]$

3. pendek $(<8 \mathrm{~mm})$

5. sedang $(8-9 \mathrm{~mm})$

7. panjang (>9 mm)

2) Lebar biji $[\mathrm{mm}]$

3. sempit $(<8 \mathrm{~mm})$

5. sedang $(8-9 \mathrm{~mm})$

7. lebar (>9 mm)

3) Jumlah biji per buah (bh)

3. Sedikit $(<3 \mathrm{bh})$

5. Menegah (3-4 bh)

7. Banyak (> 4 bh) 
4) Berat 100 biji [gram]

3.Ringan $(<5$ gr $)$

5.Sedang (5-7 gr)

7.Berat (> $7 \mathrm{gr})$

5) Bentuk biji

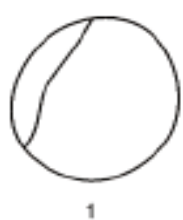

1. Spheroid

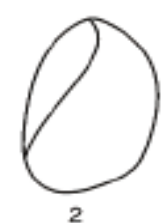

2. Ellipsoid

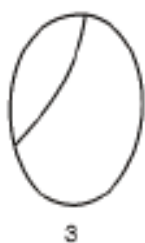

3. Oblong

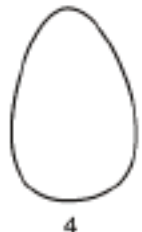

4. Ovoid

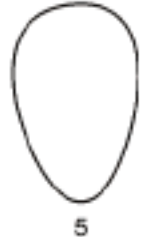

5. Obovoid

99. lain-lain

6) Warna kulit biji

1.Putih

2. Putih kekuningan

3. Kuning

99 lain-lain

* Sumber : Bioversity International Durian (Durio zibethinus), (2007), Gembong (2005), dan Pribadi 


\section{Lampiran 3: Daftar Pertanyaan dari kuisioner}

\section{Responden Petani}

Nama

Umur

Alamat

Pendidikan

Alasan Menanam :

1) Asal bibit (Diketahui/tidak diketahui)

a. Biji dikecambahkan atau ditanam langsung

- Budidaya

- Liar

b. Jika diketahui, bagaimana perbanyakan awal

- Ditanam dari benih

- Ditanam dari anakan

- Dipelihara dengan anakan tumbuh secara alami

2) Jumlah pohon yang dimiliki?

3) Apakah dilakukan pemeliharaan? (Penyiangan atau pemangkasan)

4) apakah dilakukan pemupukan?( Ya/tidak)

$\checkmark \quad$ Jika ya apa jenis pupuk yang diberikan

5) apakah pengendalian hama dan penyakit dilakukan?( Ya/tidak

Jika ya apa hama yang dominan?

6) Panen 
Bagaimana cara panen sijontiak yang telah dilakukan?

- Berapa hasil panen sijontiak (berapa buah)?

- Apa yang dilakukan terhadap buah setelah panen?

- Berapa kali berbuah dalam satu tahun? Dan pada bulan apa saja?

7) Berapa umur tanaman saat ini?

8) adakah tanaman yang mati mendadak? Jika ada apa sebabnya?

9) bagaimana rasa buah sijontiak ini?

a) Sangat manis

b) Manis

c) Agak Manis

d) Kurang Manis

e) Asam

\section{Kuisioner pejabat setempat}
A. Berapa jumlah batang sijontiak dalam satu nagari?
B. Total nagari yang mayoritas ditumbuhi sijontiak? Nagari apa?.
C. Adakah masyarakat yang membudidayakan sijontiak? (Ada/tidak) Kenapa?
D. Apakah ada rencana pemerintah daerah untuk menganjurkan penduduk untuk menanam sijontiak dalam skala besar? (ada/tidak) kenapa
E. jika ada, apa bantuan yang diberikan kepada petani sijontiak dari pemerintah? 
Lampiran 4. Peta Kabupaten Lima Puluh Kota

\section{PETA KABUPATEN LIMA PULUH KOTA}

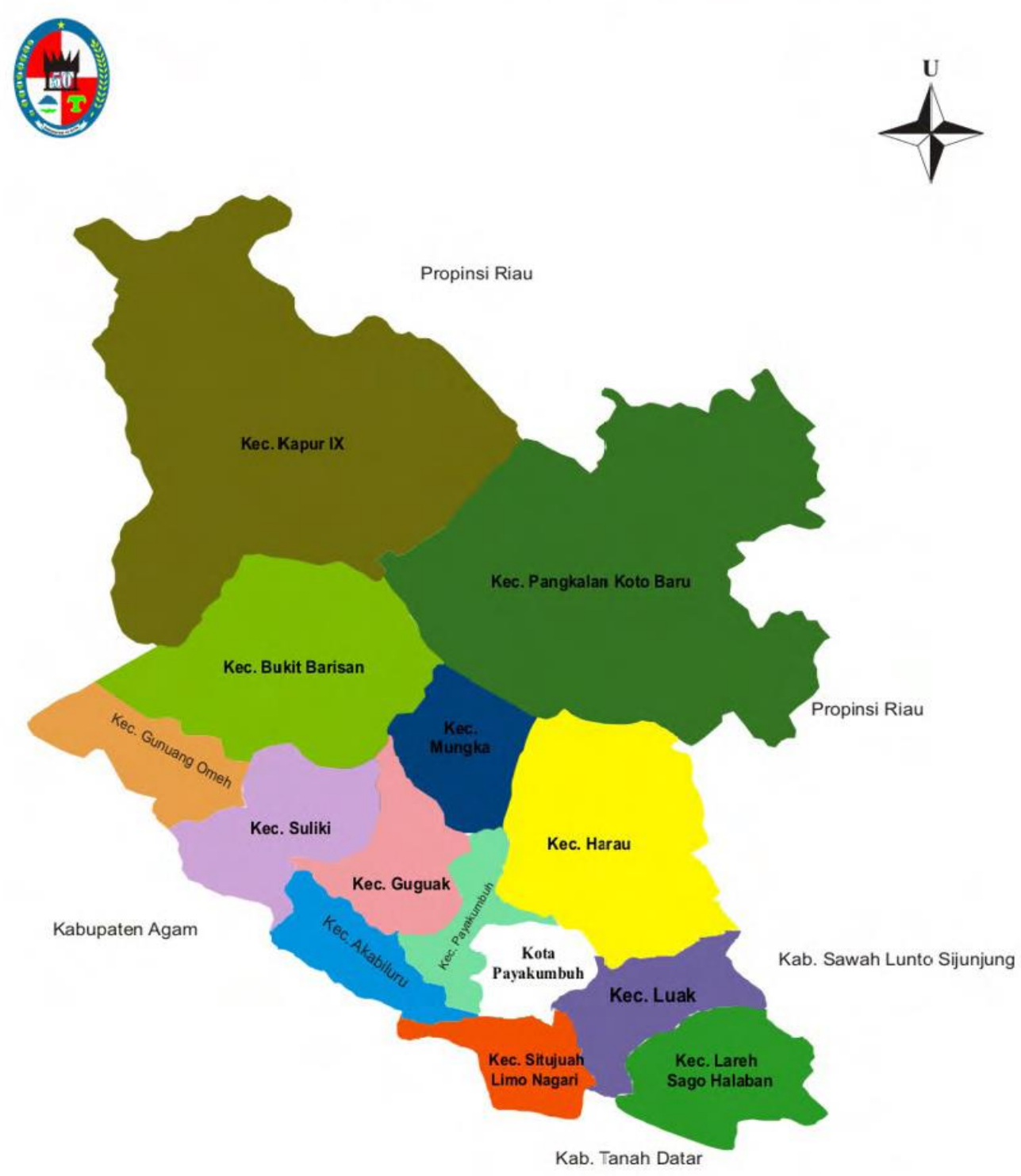

*Badan Pusat Statistik Kabupaten Lima Puluh Kota 2010. 
Lampiran 5. Peta geografis wilayah Kecamatan Guguak

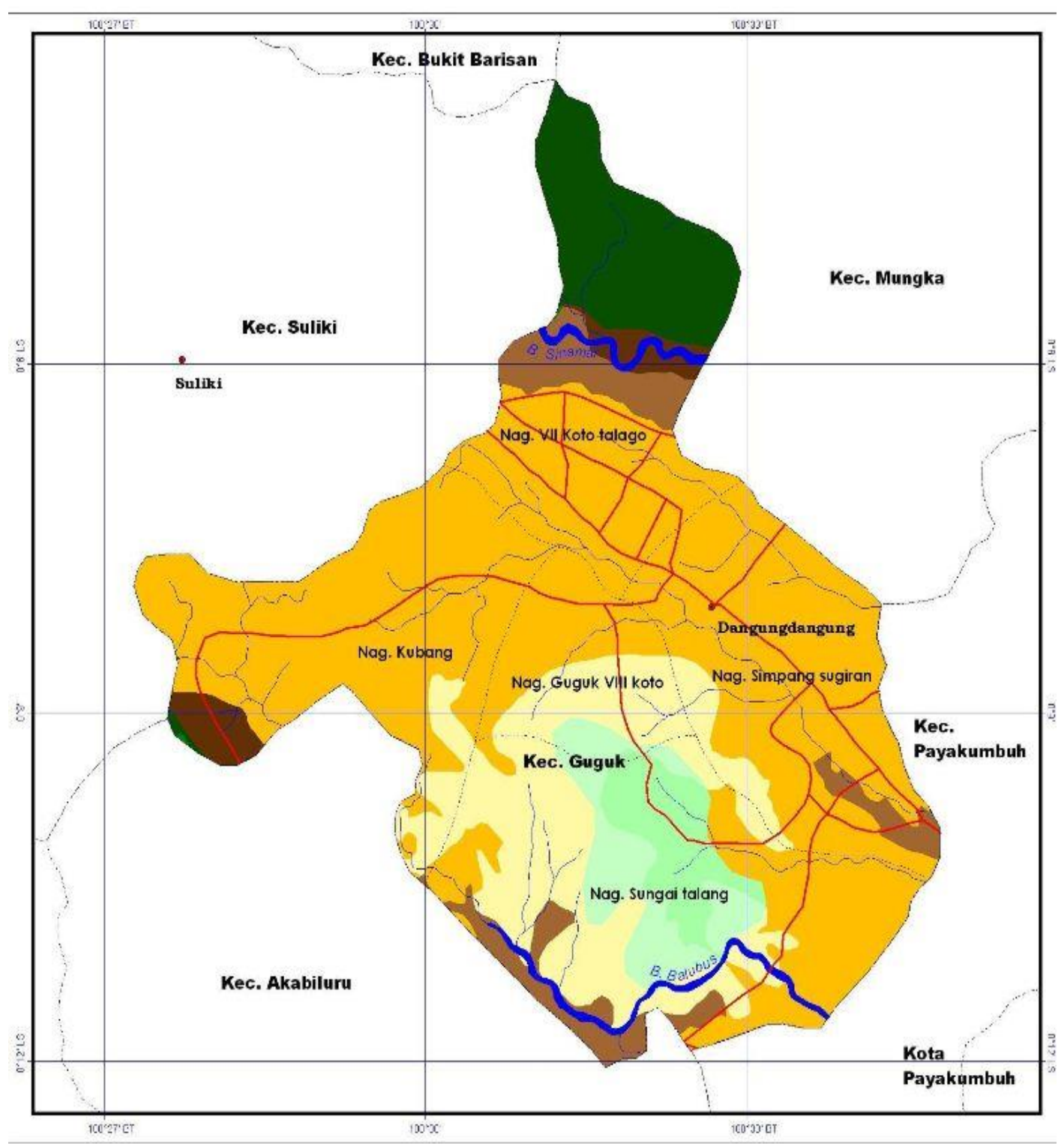

*) Sumber : www.Limapuluhkota.go.id 
Lampiran 6. Nama-Nama Kanagarian dan Jorong di Kecamatan Guguak Kabupaten Lima Puluh Kota

\begin{tabular}{|c|c|}
\hline Kanagarian & Jorong \\
\hline $\begin{array}{l}\text { 1. Kanagarian Guguak VIII } \\
\text { Koto }\end{array}$ & $\begin{array}{ll}\text { - } & \text { Kubang Tungkek } \\
\text { - } & \text { Pincuran Botuang } \\
\text { - } & \text { Balai Tolang } \\
\text { - } & \text { Katinggian } \\
\text { - } & \text { Guguak } \\
\text { - } & \text { Tiakar } \\
\text { - } & \text { Kuranji } \\
\text { - } & \text { Balai Mansiro }\end{array}$ \\
\hline 2. Kanagarian VII Koto Talago & $\begin{array}{ll}\text { - } & \text { Talago } \\
\text { - } & \text { Tanjung Jati } \\
\text { - } & \text { Koto Kociak } \\
\text { - } & \text { Ampang Godang } \\
\text { - } & \text { Padang Jopang } \\
\text { - } & \text { Padang Kandih } \\
\text { - } & \text { Sipingai }\end{array}$ \\
\hline 3. Kanagarian Simpang Sigiran & $\begin{array}{ll}\text { - } & \text { Boncah } \\
\text { - } & \text { Balik } \\
\text { - } & \text { Lokuang }\end{array}$ \\
\hline 4. Kanagarian Kubang & $\begin{array}{ll}\text { - } & \text { Kubang } \\
\text { - } & \text { Koto Baru } \\
\text { - } & \text { Lima Koto } \\
\text { - } & \text { Siamang Bunyi } \\
\text { - } & \text { Tanjung Barulak } \\
\text { - } & \text { Koto Serikat } \\
\text { - } & \text { Taratak }\end{array}$ \\
\hline 5. Kanagarian Sungai tolang & $\begin{array}{ll}- & \text { Sungai Tolang } \\
- & \text { Belubus } \\
- & \text { Guguak Nunang } \\
- & \text { Bukit Apit } \\
- & \text { Kaludan }\end{array}$ \\
\hline
\end{tabular}

*) Sumber : Badan Pusat Statistik (2009) 
Lampiran 7. Posisi geografis masing-masing tanaman sijontiak yang diamati di Kecamatan Guguak, Kabupaten Lima Puluh Kota

\begin{tabular}{|c|c|c|c|}
\hline Nama Jorong & Lintang selatan & Bujur timur & $\begin{array}{c}\text { Ketinggian } \\
\text { (m dpl) }\end{array}$ \\
\hline KT-1 & $00^{0} 08^{\prime} 10.0^{\prime \prime}$ & $100^{0} 32^{\prime} 32.8^{\prime \prime}$ & 533 \\
\hline KT-2 & $00^{0} 08^{\prime} 10.2^{\prime \prime}$ & $100^{0} 32^{\prime} 38.4$ '” & 533 \\
\hline KT-3 & $00^{0} 08^{\prime} 10.6^{\prime \prime}$ & $100^{0} 32^{\prime} 40.5^{\prime \prime}$ & 534 \\
\hline PB-1 & $00^{0} 07^{\prime} 46.3^{\prime \prime}$ & $100^{\circ} 32^{\prime} 20.8^{\prime \prime}$ & 541 \\
\hline PB-2 & $00^{0} 07^{\prime} 42.4^{\prime \prime}$ & $100^{\circ} 32^{\prime} 23.3^{\prime \prime}$ & 540 \\
\hline PB-3 & $00^{0} 07^{\prime} 47.2^{\prime \prime}$ & $100^{\circ} 32^{\prime} 24.7^{\prime \prime}$ & 542 \\
\hline BT-1 & $00^{0} 07^{\prime} 46.3^{\prime \prime}$ & $100^{0} 32^{\prime} 20.8^{\prime \prime}$ & 541 \\
\hline BT-2 & $00^{0} 07^{\prime} 30.5^{\prime \prime}$ & $100^{0} 32^{\prime} 22.3^{\prime \prime}$ & 543 \\
\hline BT-3 & $00^{0} 07^{\prime} 44.6 "$ & $100^{0} 32^{\prime} 24.8^{\prime \prime}$ & 543 \\
\hline KN-1 & $00^{0} 07^{\prime} 51.7^{\prime \prime}$ & $100^{0} 33^{\prime} 12.0^{\prime \prime}$ & 545 \\
\hline KN-2 & $00^{0} 07^{\prime} 35.7^{\prime \prime}$ & $100^{0} 33^{\prime} 14.3^{\prime \prime}$ & 545 \\
\hline KN-3 & $00^{0} 06 ' 55.7 ”$ & $100^{0} 33^{\prime} 18.5^{\prime \prime}$ & 543 \\
\hline KN-4 & $00^{0} 06^{\prime} 45.7^{\prime \prime}$ & $100^{0} 33^{\prime} 22.4^{\prime \prime}$ & 546 \\
\hline KN-5 & $00^{0} 06^{\prime} 57.5^{\prime \prime}$ & $100^{0} 33^{\prime} 24.0^{\prime \prime}$ & 545 \\
\hline GK-1 & $00^{0} 09^{\prime} 06.0^{\prime \prime}$ & $100^{0} 33^{\prime} 56.6^{\prime \prime}$ & 533 \\
\hline GK-2 & $00^{0} 09^{\prime} 05.8^{\prime \prime}$ & $100^{0} 33^{\prime} 56.7^{\prime \prime}$ & 542 \\
\hline GK-3 & $00^{0} 08^{\prime} 49.0^{\prime \prime}$ & $100^{0} 33^{\prime} 12.0^{\prime \prime}$ & 542 \\
\hline GK-4 & $00^{0} 08^{\prime} 34.0^{\prime \prime}$ & $100^{0} 33^{\prime} 16.1^{\prime \prime}$ & 543 \\
\hline GK-5 & $00^{0} 08^{\prime} 42.0^{\prime \prime}$ & $100^{0} 33^{\prime} 20.4^{\prime \prime}$ & 543 \\
\hline GK-6 & $00^{0} 08^{\prime} 40.0^{\prime \prime}$ & $100^{0} 33^{\prime} 21.3 ”$ & 543 \\
\hline TR-1 & 0009'14.9"' & $100^{\circ} 33^{\prime} 26.5^{\prime \prime}$ & 548 \\
\hline
\end{tabular}




\begin{tabular}{|c|c|c|c|}
\hline TR-2 & $00^{0} 09^{\prime} 16.9$ ' & $100^{\circ} 33^{\prime} 26.3^{\prime \prime}$ & 546 \\
\hline TR-3 & $00^{0} 09^{\prime} 13.9^{\prime \prime}$ & $100^{\circ} 33^{\prime} 25.1^{\prime \prime}$ & 547 \\
\hline TR-4 & $00^{0} 09^{\prime} 18.9^{\prime \prime}$ & $100^{\circ} 33^{\prime} 25.4^{\prime \prime}$ & 547 \\
\hline TR-5 & $00^{0} 09^{\prime} 20.9^{\prime \prime}$ & $100^{\circ} 33^{\prime} 25.7^{\prime \prime}$ & 547 \\
\hline KI-1 & $00^{0} 09^{\prime} 55.8^{\prime \prime}$ & $100^{\circ} 33^{\prime} 57.6^{\prime \prime}$ & 529 \\
\hline KI-2 & $00^{0} 09^{\prime} 50.8^{\prime \prime}$ & $100^{\circ} 33^{\prime} 57.4^{\prime \prime}$ & 529 \\
\hline KI-3 & $00^{0} 09^{\prime} 43.8^{\prime \prime}$ & $100^{\circ} 33^{\prime} 56.2^{\prime \prime}$ & 529 \\
\hline KI-4 & $00^{0} 08^{\prime} 42.8^{\prime \prime}$ & $100^{\circ} 33^{\prime} 57.3^{\prime \prime}$ & 528 \\
\hline KI-5 & $00^{0} 08^{\prime} 45.8^{\prime \prime}$ & $100^{\circ} 33^{\prime} 57.7^{\prime \prime}$ & 528 \\
\hline KI-6 & $00^{0} 08^{\prime} 50.8^{\prime \prime}$ & $100^{\circ} 33^{\prime} 57.2^{\prime \prime}$ & 527 \\
\hline KI-7 & $00^{0} 08^{\prime} 55.8^{\prime \prime}$ & $100^{\circ} 33^{\prime} 57.8^{\prime \prime}$ & 527 \\
\hline KI-8 & $00^{0} 08^{\prime} 59.8^{\prime \prime}$ & $100^{\circ} 33^{\prime} 56.1^{\prime \prime}$ & 529 \\
\hline KI-9 & $00^{0} 08^{\prime} 56.8^{\prime \prime}$ & $100^{\circ} 33^{\prime} 56.3^{\prime \prime}$ & 529 \\
\hline KI-10 & $00^{0} 08^{\prime} 57.8^{\prime \prime}$ & $100^{\circ} 33^{\prime} 56.5^{\prime \prime}$ & 529 \\
\hline TO-1 & $00^{0} 07^{\prime} 25.9^{\prime \prime}$ & $100^{\circ} 31^{\prime} 19.2^{\prime \prime}$ & 564 \\
\hline TO-2 & $00^{0} 07^{\prime} 30.9$ ' & $100^{\circ} 31^{\prime} 19.5^{\prime \prime}$ & 565 \\
\hline TJ-1 & $00^{0} 06^{\prime} 41.2^{\prime \prime}$ & $100^{\circ} 31^{\prime} 21.2^{\prime \prime}$ & 562 \\
\hline TJ-2 & $00^{0} 06^{\prime} 41.8^{\prime \prime}$ & $100^{\circ} 31^{\prime} 20.4^{\prime \prime}$ & 558 \\
\hline KK-1 & $00^{0} 06^{\prime} 18.3^{\prime \prime}$ & $100^{\circ} 31^{\prime} 41.6^{\prime \prime}$ & 558 \\
\hline KK-2 & $00^{0} 06^{\prime} 22.3^{\prime \prime}$ & $100^{\circ} 31^{\prime} 41.8^{\prime \prime}$ & 558 \\
\hline AG-1 & $00^{0} 06^{\prime} 53.8^{\prime \prime}$ & $100^{\circ} 31^{\prime} 57.8^{\prime \prime}$ & 559 \\
\hline AG-2 & $00^{0} 06^{\prime} 58.8^{\prime \prime}$ & $100^{\circ} 31 ' 57.4 "$ & 559 \\
\hline PK-1 & $00^{0} 07^{\prime} 32.9$ ' & $100^{\circ} 31^{\prime} 55.1^{\prime \prime}$ & 562 \\
\hline SI-1 & $00^{0} 07^{\prime} 35.5^{\prime \prime}$ & $100^{\circ} 31^{\prime} 57.3^{\prime \prime}$ & 562 \\
\hline PJ-1 & $00^{0} 06^{\prime} 33.8^{\prime \prime}$ & $100^{\circ} 32^{\prime} 08.2^{\prime \prime}$ & 535 \\
\hline
\end{tabular}




\begin{tabular}{|c|c|c|c|}
\hline BK-1 & $00^{0} 10^{\prime} 55.8^{\prime \prime}$ & $100^{\circ} 30^{\prime} 50.8^{\prime \prime}$ & 568 \\
\hline BK-2 & $00^{0} 10^{\prime} 55.8^{\prime \prime}$ & $100^{\circ} 30^{\prime} 51.1^{\prime \prime}$ & 580 \\
\hline BK-3 & $00^{0} 10^{\prime} 55.8^{\prime \prime}$ & $100^{\circ} 30^{\prime} 51.1^{\prime \prime}$ & 580 \\
\hline BH-1 & $00^{0} 11^{\prime} 40.8^{\prime \prime}$ & $100^{\circ} 30^{\prime} 58.7^{\prime \prime}$ & 582 \\
\hline LG-1 & $00^{0} 11^{\prime} 53.8^{\prime \prime}$ & $100^{\circ} 30^{\prime} 48.4^{\prime \prime}$ & 581 \\
\hline KG-1 & $00^{0} 08^{\prime} 08.5^{\prime \prime}$ & $100^{\circ} 31^{\prime \prime 29.2 "}$ & 536 \\
\hline KG-2 & $00^{0} 08^{\prime} 18.3^{\prime \prime}$ & $100^{\circ} 31^{\prime} 22.3^{\prime \prime}$ & 552 \\
\hline KG-3 & $00^{0} 08^{\prime} 21.4^{\prime \prime}$ & $100^{\circ} 31^{\prime} 24.4^{\prime \prime}$ & 552 \\
\hline KG-4 & $00^{0} 08^{\prime} 26.4^{\prime \prime}$ & $100^{\circ} 31^{\prime 2} 26.2^{\prime \prime}$ & 553 \\
\hline KG-5 & $00^{0} 08^{\prime} 30.4^{\prime \prime}$ & $100^{\circ} 31^{\prime 26.5 "}$ & 553 \\
\hline KB-1 & $00^{0} 08^{\prime} 14.4^{\prime \prime}$ & $100^{\circ} 31^{\prime} 22.0^{\prime \prime}$ & 553 \\
\hline 5.KO-1 & $00^{0} 08^{\prime} 17.6^{\prime \prime}$ & $100^{\circ} 30^{\prime} 20.9^{\prime \prime}$ & 583 \\
\hline SB-1 & $00^{0} 08^{\prime} 30.0^{\prime \prime}$ & $100^{\circ} 28^{\prime} 26.0^{\prime \prime}$ & 807 \\
\hline ST-1 & $00^{0} 10^{\prime} 00.4^{\prime \prime}$ & $100^{\circ} 32^{\prime} 12.1^{\prime \prime}$ & 561 \\
\hline BS-1 & $00^{0} 10^{\prime} 58.0^{\prime \prime}$ & $100^{\circ} 33^{\prime} 22.1^{\prime \prime}$ & 546 \\
\hline GN-1 & $00^{0} 10^{\prime} 30.3^{\prime \prime}$ & $100^{\circ} 34^{\prime} 20.9^{\prime \prime}$ & 525 \\
\hline BA-1 & $00^{0} 11^{\prime} 43.8^{\prime \prime}$ & $100^{\circ} 32^{\prime} 44.2^{\prime \prime}$ & 566 \\
\hline
\end{tabular}


Lampiran 8. Data morfologis tanaman Sijontiak yang diamati di Kabupaten Lima Puluh Kota

\begin{tabular}{|c|c|c|c|c|}
\hline $\begin{array}{c}\text { No. } \\
\text { Aksesi }\end{array}$ & $\begin{array}{c}\text { Tinggi } \\
\text { tanaman } \\
(\mathbf{m})\end{array}$ & $\begin{array}{c}\text { Bentuk } \\
\text { tajuk }\end{array}$ & $\begin{array}{c}\text { Tipe Percabangan } \\
\text { Tanaman }\end{array}$ & $\begin{array}{c}\text { Arah Tumbuh } \\
\text { Batang }\end{array}$ \\
\hline KT-1 & 20,65 & Spherical & Intermediate & Keatas \\
\hline KT-2 & 25,30 & Oblong & Spreading & Keluar \\
\hline KT-3 & 27,12 & Oblong & Intermediate & Keatas \\
\hline PB-1 & 21,84 & Oblong & Erect & Keatas \\
\hline PB-2 & 25,10 & Elliptical & Erect & Keatas \\
\hline PB-3 & 27,13 & Oblong & Intermediate & Keatas \\
\hline BT-1 & 23,93 & Pyramidal & Erect & Keatas \\
\hline BT-2 & 28,88 & Elliptical & Spreading & Keluar \\
\hline BT-3 & 15,56 & Pyramidal & Intermediate & Keatas \\
\hline $\mathrm{KN}-1$ & 28,87 & Pyramidal & Spreading & Keluar \\
\hline $\mathrm{KN}-2$ & 26,65 & Elliptical & Intermediate & Keatas \\
\hline KN-3 & 23,32 & Spherical & Erect & Keatas \\
\hline $\mathrm{KN}-4$ & 25,12 & Phyramidal & Intermediate & Keatas \\
\hline $\mathrm{KN}-5$ & 26.16 & Elliptical & Erect & Keatas \\
\hline GK-1 & 15,50 & Pyramidal & Intermediate & Keatas \\
\hline GK-2 & 22,66 & Spherical & Erect & Keatas \\
\hline GK-3 & 23,80 & Spherical & Erect & Keatas \\
\hline GK-4 & 29,22 & Pyramidal & Intermediate & Keatas \\
\hline GK-5 & 27,00 & Oblong & Spreading & Keluar \\
\hline GK-6 & 25,75 & Pyramidal & Erect & Ketas \\
\hline TR-1 & 26,40 & Spherical & Erect & Keatas \\
\hline
\end{tabular}




\begin{tabular}{|c|c|c|c|c|}
\hline TR-2 & 17,13 & Phyramidal & Spreading & Keluar \\
\hline TR-3 & 25,40 & Oblong & Erect & Keatas \\
\hline TR-4 & 26,00 & Pyramidal & Erect & Ketas \\
\hline TR-5 & 24,67 & Phyramidal & Intermediate & Keatas \\
\hline KI-1 & 26,10 & Spherical & Spreading & Keluar \\
\hline KI-2 & 24,21 & Oblong & Erect & Keatas \\
\hline KI-3 & 26,18 & Oblong & Erect & Keatas \\
\hline KI-4 & 26,21 & Spherical & Erect & Keatas \\
\hline KI-5 & 25,56 & Phyramidal & Spreading & Keluar \\
\hline KI-6 & 27,14 & Oblong & Spreading & Keluar \\
\hline KI-7 & 27,18 & Oblong & Erect & Keatas \\
\hline KI-8 & 27,26 & Phyramidal & Erect & Keatas \\
\hline KI-9 & 30,12 & Elliptical & Intermediate & Keatas \\
\hline KI-10 & 26,15 & Elliptical & Erect & Keatas \\
\hline TO-1 & 21,85 & Elliptical & Intermediate & Keatas \\
\hline TO-2 & 27,25 & Elliptical & Spreading & Keluar \\
\hline TJ-1 & 19,00 & Oblong & Erect & Keatas \\
\hline TJ-2 & 32,30 & Pyramidal & Intermediate & Keatas \\
\hline KK-1 & 21,37 & Spherical & Erect & Keatas \\
\hline KK-2 & 25,34 & Pyramidal & Erect & Keatas \\
\hline AG-1 & 22,05 & Elliptical & Erect & Keatas \\
\hline AG-2 & 26,12 & Oblong & Intermediate & Keatas \\
\hline PK-1 & 29,14 & Spherical & Intermediate & Keluar \\
\hline SI-1 & 27,73 & Spherical & Erect & Keatas \\
\hline PJ-1 & 26,34 & Spherical & Erect & Keatas \\
\hline
\end{tabular}




\begin{tabular}{|c|c|c|c|c|}
\hline BK-1 & 24,10 & Spherical & Erect & Keatas \\
\hline BK-2 & 23,05 & Oblong & Intermediate & Keatas \\
\hline BK-3 & 22,10 & Oblong & Intermediate & Keatas \\
\hline BH-1 & 29,80 & Phyramidal & Intermediate & Keatas \\
\hline LG-1 & 29,80 & Spherical & Intermediate & Keatas \\
\hline KG-1 & 28,60 & Oblong & Intermediate & Keatas \\
\hline KG-2 & 25,52 & Elliptical & Erect & Keatas \\
\hline KG-3 & 27,72 & Oblong & Intermediate & Keatas \\
\hline KG-4 & 28,82 & Oblong & Intermediate & Keatas \\
\hline KG-5 & 29,32 & Spherical & Intermediate & Keatas \\
\hline KB-1 & 28,65 & Spherical & Intermediate & Keatas \\
\hline 5 KT-1 & 22,80 & Spherical & Erect & Keatas \\
\hline SB-1 & 30,62 & Spherical & Erect & Keatas \\
\hline ST-1 & 30,65 & Spherical & Intermediate & Keluar \\
\hline BS-1 & 35,60 & Oblong & Erect & Keatas \\
\hline GN-1 & 29,22 & Pyramidal & Intermediate & Keatas \\
\hline BA-1 & 30,37 & Spherical & Spreading & Keluar \\
\hline
\end{tabular}


Lampiran 9. Data Morfologis Batang Tanaman Sijontiak di Kabupaten Lima Puluh Kota

\begin{tabular}{|c|c|c|c|c|}
\hline $\begin{array}{c}\text { No. } \\
\text { Aksesi }\end{array}$ & Bentuk Batang & $\begin{array}{c}\text { Lingkaran } \\
\text { batang } \\
\text { (cm) }\end{array}$ & $\begin{array}{c}\text { Permukaan } \\
\text { batang }\end{array}$ & $\begin{array}{c}\text { Warna kulit } \\
\text { batang }\end{array}$ \\
\hline KT-1 & Bulat & 99 & Agak kasar & Coklat \\
\hline KT-2 & Bulat & 162 & Kasar & Coklat Tua \\
\hline KT-3 & Bulat & 79 & Sangat kasar & Abu-abu \\
\hline PB-1 & Bulat & 125 & Kasar & Coklat muda \\
\hline PB-2 & Bulat & 118 & Kasar & Coklat muda \\
\hline PB-3 & Bulat & 98 & Agak kasar & Coklat muda \\
\hline BT-1 & Bulat & 195 & Kasar & Abu-abu \\
\hline BT-2 & Bulat & 187 & Kasar & Coklat \\
\hline BT-3 & Bulat & 65 & Agak kasar & Coklat muda \\
\hline KN-1 & Bulat & 97 & Kasar & Coklat \\
\hline KN-2 & Bulat & 99 & Agak kasar & Coklat muda \\
\hline KN-3 & Bulat & 102 & Kasar & Coklat muda \\
\hline KN-4 & Bulat & 85 & Agak kasar & Coklat muda \\
\hline KN-5 & Bulat & 105 & Agak kasar & Coklat \\
\hline GK-1 & Bulat & 51 & Kasar & Coklat muda \\
\hline GK-2 & Bulat & 172 & Kasar & Coklat tua \\
\hline GK-3 & Bulat & 155 & Kasar & Coklat \\
\hline GK-4 & Bulat & 190 & Kasar & Coklat muda \\
\hline GK-5 & Bulat & 197 & Agak kasar & Coklat muda \\
\hline GK-6 & Bulat & 115 & Kasar & Coklat muda \\
\hline TR-1 & Bulat & 212 & Kasar & Coklat \\
\hline
\end{tabular}




\begin{tabular}{|c|c|c|c|c|}
\hline TR-2 & Bulat & 73 & Agak kasar & Coklat muda \\
\hline TR-3 & Bulat & 98 & Agak kasar & Coklat muda \\
\hline TR-4 & Bulat & 118 & Agak kasar & Coklat muda \\
\hline TR-5 & Bulat & 186 & Kasar & Coklat \\
\hline KI-1 & Bulat & 189 & Sangat Kasar & Coklat muda \\
\hline KI-2 & Bulat & 130 & Kasar & Coklat Tua \\
\hline KI-3 & Bulat & 89 & Kasar & Coklat \\
\hline KI-4 & Bulat & 158 & Kasar & Coklat \\
\hline KI-5 & Bulat & 196 & Agak kasar & Coklat muda \\
\hline KI-6 & Bulat & 115 & Agak kasar & Coklat \\
\hline KI-7 & Bulat & 118 & Kasar & Coklat tua \\
\hline KI-8 & Bulat & 184 & Kasar & Coklat muda \\
\hline KI-9 & Bulat & 112 & Agak kasar & Coklat muda \\
\hline KI-10 & Bulat & 117 & Sangat kasar & Coklat \\
\hline TO-1 & Bulat & 156 & Sangat kasar & Coklat muda \\
\hline TO-2 & Bulat & 126 & Kasar & Coklat \\
\hline TJ-1 & Bulat & 80 & Kasar & Coklat muda \\
\hline TJ-2 & Bulat & 127 & Agak kasar & Coklat muda \\
\hline KK-1 & Bulat & 107 & Kasar & Coklat \\
\hline KK-2 & Bulat & 95 & Agak kasar & Coklat muda \\
\hline AG-1 & Bulat & 93 & Kasar & Coklat muda \\
\hline AG-2 & Bulat & 92 & Kasar & Coklat muda \\
\hline PJ-1 & Bulat & 142 & Sangat Kasar & Coklat tua \\
\hline PK-1 & Bulat & 192 & Kasar & Coklat muda \\
\hline SI-1 & Bulat & 152 & Kasar & Coklat \\
\hline
\end{tabular}




\begin{tabular}{|c|c|c|l|l|}
\hline BK-1 & Bulat & 105 & Agak kasar & Coklat muda \\
\hline BK-2 & Bulat & 117 & Kasar & Coklat \\
\hline BK-3 & Bulat & 94 & Agak kasar & Coklat \\
\hline BH-1 & Bulat & 118 & Kasar & Coklat \\
\hline LG-1 & Bulat & 101 & Kasar & Coklat muda \\
\hline KG-1 & Bulat & 142 & Kasar & Coklat \\
\hline KG-2 & Bulat & 108 & Kasar & Coklat \\
\hline KG-3 & Bulat & 85 & Agak kasar & Coklat \\
\hline KG-4 & Bulat & 125 & Kasar & Coklat \\
\hline KG-5 & Bulat & 101 & Agak kasar & Coklat muda \\
\hline KB-1 & Bulat & 150 & Kasar & Coklat muda \\
\hline 5KT-1 & Bulat & 126 & Kasar & Coklat \\
\hline SB-1 & Bulat & 221 & Kasar & Coklat \\
\hline ST-1 & Bulat & 201 & Kasar & Coklat muda \\
\hline BS-1 & Bulat & 302 & Sangat kasar & Coklat \\
\hline GN-1 & Bulat & 101 & Kasar & Coklat \\
\hline BA-1 & Bulat & 191 & Kasar & Coklat \\
\hline
\end{tabular}


Lampiran 10. Data morfologis daun tanaman sijontiak yang diamati di Kecamatan Guguak, Kabupaten Lima Puluh Kota

\begin{tabular}{|c|c|c|c|c|c|c|c|c|c|c|}
\hline $\begin{array}{l}\text { No } \\
\text { Aksesi }\end{array}$ & $\begin{array}{l}\text { Panjang } \\
\text { Daun }\end{array}$ & $\begin{array}{l}\text { Lebar } \\
\text { Daun }\end{array}$ & $\begin{array}{l}\text { Panjang } \\
\text { Tangkai } \\
\text { Daun }\end{array}$ & \multirow[t]{2}{*}{$\begin{array}{l}\text { Ujung } \\
\text { Daun }\end{array}$} & \multirow[t]{2}{*}{$\begin{array}{l}\text { Pangkal } \\
\text { Daun }\end{array}$} & \multirow[t]{2}{*}{$\begin{array}{l}\text { Warna } \\
\text { Daun }\end{array}$} & \multirow[t]{2}{*}{$\begin{array}{l}\text { Permukaan } \\
\text { Daun }\end{array}$} & \multirow[t]{2}{*}{$\begin{array}{l}\text { Bentuk } \\
\text { Helaian } \\
\text { Daun }\end{array}$} & \multirow[t]{2}{*}{$\begin{array}{l}\text { Tepi } \\
\text { Daun }\end{array}$} & \multirow[t]{2}{*}{ Tulang Daun } \\
\hline & \multicolumn{3}{|c|}{$\begin{array}{c}\text { Rata-Rata } \\
(\mathrm{cm})\end{array}$} & & & & & & & \\
\hline KT-1 & 19.00 & 7.50 & 4.67 & Meruncing & Membulat & Hijau & Halus & Ovate & Rata & Menyirip \\
\hline KT-2 & 17,33 & 7,20 & 4,00 & Meruncing & Membulat & $\begin{array}{l}\text { Hijau } \\
\text { tua }\end{array}$ & Kasar & Elliptic & Rata & Menyirip \\
\hline KT-3 & 16.67 & 6,20 & 4,17 & Meruncing & Membulat & $\begin{array}{l}\text { Hijau } \\
\text { tua }\end{array}$ & Kasar & Elliptic & Rata & Menyirip \\
\hline PB-1 & 19.00 & 8.50 & 5.33 & Meruncing & Membulat & Hijau & Halus & Elliptic & Rata & Menyirip \\
\hline PB-2 & 15,33 & 5,62 & 3,00 & Meruncing & Membulat & $\begin{array}{l}\text { Hijau } \\
\text { tua }\end{array}$ & Kasar & Elliptic & Rata & Menyirip \\
\hline PB-3 & 18,67 & 6,10 & 3,33 & Meruncing & Membulat & $\begin{array}{l}\text { Hijau } \\
\text { tua }\end{array}$ & Kasar & Elliptic & Rata & Menyirip \\
\hline BT-1 & 19.00 & 7.23 & 5.83 & Meruncing & Membulat & $\begin{array}{l}\text { Hijau } \\
\text { tua }\end{array}$ & Kasar & Elliptic & Rata & Menyirip \\
\hline
\end{tabular}




\begin{tabular}{|c|c|c|c|c|c|c|c|c|c|c|}
\hline BT-2 & 15,33 & 5,17 & 3,00 & Meruncing & Membulat & $\begin{array}{l}\text { Hijau } \\
\text { tua }\end{array}$ & Kasar & Elliptic & Rata & Menyirip \\
\hline BT-3 & 13,67 & 6,12 & 3,00 & Meruncing & Berlekuk & $\begin{array}{l}\text { Hijau } \\
\text { tua }\end{array}$ & Kasar & Obovatus & Rata & Menyirip \\
\hline KN-1 & 21.53 & 7.47 & 5.33 & Meruncing & Membulat & Hijau & Kasar & Elliptic & Rata & Menyirip \\
\hline KN-2 & 16,67 & 5,68 & 3,00 & Meruncing & Membulat & Hijau & Kasar & Elliptic & Rata & Menyirip \\
\hline KN-3 & 15,67 & 6,02 & 3,00 & Meruncing & Membulat & $\begin{array}{l}\text { Hijau } \\
\text { tua }\end{array}$ & Kasar & Elliptic & Rata & Menyirip \\
\hline KN-4 & 15,67 & 6,25 & 2,67 & Meruncing & Membulat & $\begin{array}{l}\text { Hijau } \\
\text { tua }\end{array}$ & Kasar & Elliptic & Rata & Menyirip \\
\hline KN-5 & 14,33 & 6,48 & 3,00 & Runcing & Berlekuk & $\begin{array}{l}\text { Hijau } \\
\text { tua }\end{array}$ & Halus & Elliptic & Rata & Menyirip \\
\hline GK-1 & 16.00 & 7.67 & 3.23 & Meruncing & Berlekuk & Hijau & Halus & Eliptic & Rata & Menyirip \\
\hline GK-2 & 14.00 & 6.13 & 4.33 & Meruncing & Berlekuk & Hijau & Halus & Eliptic & Rata & Menyirip \\
\hline GK-3 & 17.33 & 5.67 & 3.33 & Meruncing & Berlekuk & $\begin{array}{l}\text { Hijau } \\
\text { muda }\end{array}$ & Halus & Eliptic & Rata & Menyirip \\
\hline GK-4 & 15,00 & 5,56 & 3,67 & Runcing & Berlekuk & $\begin{array}{l}\text { Hijau } \\
\text { tua }\end{array}$ & Kasar & Ovate & Rata & Menyirip \\
\hline
\end{tabular}




\begin{tabular}{|c|c|c|c|c|c|c|c|c|c|c|}
\hline GK-5 & 14,00 & 6,0 & 3,33 & Meruncing & Membulat & $\begin{array}{l}\text { Hijau } \\
\text { tua }\end{array}$ & Kasar & Elliptic & Rata & Menyirip \\
\hline GK-6 & 14,67 & 6,12 & 3,67 & Meruncing & Membulat & $\begin{array}{l}\text { Hijau } \\
\text { tua }\end{array}$ & Kasar & Elliptic & Rata & Menyirip \\
\hline TR-1 & 18.33 & 7.50 & 5.17 & Meruncing & Membulat & $\begin{array}{l}\text { Hijau } \\
\text { tua }\end{array}$ & Kasar & Elliptic & Rata & Menyirip \\
\hline TR-2 & 14,33 & 6,05 & 2,67 & Runcing & Berlekuk & $\begin{array}{l}\text { Hijau } \\
\text { tua }\end{array}$ & Kasar & Ovate & Rata & Menyirip \\
\hline TR-3 & 14,33 & 6,48 & 3,00 & Runcing & Membulat & Hijau & Halus & Elliptic & Rata & Menyirip \\
\hline TR-4 & 14,22 & 6,24 & 3,00 & Meruncing & Membulat & $\begin{array}{l}\text { Hijau } \\
\text { tua }\end{array}$ & Halus & Ovate & Rata & Menyirip \\
\hline TR-5 & 17,23 & 6,25 & 3,56 & Meruncing & Membulat & $\begin{array}{l}\text { Hijau } \\
\text { tua }\end{array}$ & Kasar & Elliptic & Rata & Menyirip \\
\hline KI-1 & 14.67 & 6.33 & 4.50 & Meruncing & Membulat & Hijau & Kasar & Elliptic & Rata & Menyirip \\
\hline KI-2 & 14,33 & 6,28 & 3,33 & Meruncing & Berlekuk & $\begin{array}{l}\text { Hijau } \\
\text { tua }\end{array}$ & Kasar & Ovate & Rata & Menyirip \\
\hline KI-3 & 17,00 & 6,12 & 3,00 & Runcing & Membulat & $\begin{array}{l}\text { Hijau } \\
\text { tua }\end{array}$ & Kasar & Ovate & Rata & Menyirip \\
\hline
\end{tabular}




\begin{tabular}{|c|c|c|c|c|c|c|c|c|c|c|}
\hline KI-4 & 16,33 & 5,48 & 2,67 & Meruncing & Membulat & $\begin{array}{l}\text { Hijau } \\
\text { tua }\end{array}$ & Kasar & Elliptic & Rata & Menyirip \\
\hline KI-5 & 13,33 & 5,35 & 3,67 & Meruncing & Membulat & $\begin{array}{l}\text { Hijau } \\
\text { tua }\end{array}$ & Kasar & Elliptic & Rata & Menyirip \\
\hline KI-6 & 15,67 & 6,10 & 3,67 & Runcing & Membulat & $\begin{array}{l}\text { Hijau } \\
\text { tua }\end{array}$ & Kasar & Elliptic & Rata & Menyirip \\
\hline KI-7 & 14,00 & 6,02 & 3,00 & Meruncing & Membulat & $\begin{array}{l}\text { Hijau } \\
\text { tua }\end{array}$ & Kasar & Elliptic & Rata & Menyirip \\
\hline KI-8 & 15,33 & 6,10 & 3,00 & Meruncing & Membulat & $\begin{array}{l}\text { Hijau } \\
\text { tua }\end{array}$ & Kasar & Elliptic & Rata & Menyirip \\
\hline KI-9 & 15,33 & 6,17 & 3,67 & Meruncing & Berlekuk & $\begin{array}{l}\text { Hijau } \\
\text { tua }\end{array}$ & Kasar & Elliptic & Rata & Menyirip \\
\hline KI-10 & 12,67 & 6,26 & 3,67 & Meruncing & Berlekuk & $\begin{array}{l}\text { Hijau } \\
\text { tua }\end{array}$ & Kasar & Elliptic & Rata & Menyirip \\
\hline TO-1 & 16.67 & 6.50 & 4.67 & Runcing & Berlekuk & Hijau & Halus & Ovate & Rata & Menyirip \\
\hline TO-2 & 14,00 & 6,13 & 3,67 & Meruncing & Membulat & $\begin{array}{l}\text { Hijau } \\
\text { tua }\end{array}$ & Kasar & Elliptic & Rata & Menyirip \\
\hline TJ-1 & 16.00 & 6.50 & 3.50 & Runcing & Berlekuk & $\begin{array}{l}\text { Hijau } \\
\text { tua }\end{array}$ & Halus & Ovate & Rata & Menyirip \\
\hline
\end{tabular}




\begin{tabular}{|c|c|c|c|c|c|c|c|c|c|c|}
\hline TJ-2 & 15.17 & 7.17 & 3.50 & Runcing & Berlekuk & $\begin{array}{l}\text { Hijau } \\
\text { muda }\end{array}$ & Halus & Ovate & Rata & Menyirip \\
\hline KK-1 & 17.67 & 8.67 & 3.83 & Runcing & Berlekuk & $\begin{array}{l}\text { Hijau } \\
\text { tua }\end{array}$ & Halus & Eliptic & Rata & Menyirip \\
\hline KK-2 & 15,33 & 6,60 & 3,67 & Runcing & Membulat & $\begin{array}{l}\text { Hijau } \\
\text { tua }\end{array}$ & Kasar & Ovate & Rata & Menyirip \\
\hline AG-1 & 16.33 & 6.67 & 5.33 & Runcing & Membulat & $\begin{array}{l}\text { Hijau } \\
\text { muda }\end{array}$ & Kasar & Elliptic & Rata & Menyirip \\
\hline AG-2 & 14,33 & 5,78 & 3,67 & Meruncing & Membulat & $\begin{array}{l}\text { Hijau } \\
\text { tua }\end{array}$ & Kasar & Elliptic & Rata & Menyirip \\
\hline PJ-1 & 17.33 & 8.17 & 6.00 & Runcing & Membulat & $\begin{array}{l}\text { Hijau } \\
\text { tua }\end{array}$ & Kasar & Ovate & Rata & Menyirip \\
\hline PK-1 & 14,67 & 5,65 & 4,00 & Meruncing & Membulat & $\begin{array}{l}\text { Hijau } \\
\text { tua }\end{array}$ & Kasar & Elliptic & Rata & Menyirip \\
\hline SI-1 & 13,67 & 5,45 & 3,33 & Meruncing & Membulat & $\begin{array}{l}\text { Hijau } \\
\text { tua }\end{array}$ & Kasar & Elliptic & Rata & Menyirip \\
\hline BK-1 & 16.33 & 7.90 & 4.67 & Runcing & Membulat & $\begin{array}{l}\text { Hijau } \\
\text { tua }\end{array}$ & Kasar & Elliptic & Rata & Menyirip \\
\hline BK-2 & 15.67 & 7.33 & 5.33 & Meruncing & Membulat & $\begin{array}{l}\text { Hijau } \\
\text { tua }\end{array}$ & Kasar & Eliptic & Rata & Menyirip \\
\hline
\end{tabular}




\begin{tabular}{|c|c|c|c|c|c|c|c|c|c|c|}
\hline BK-3 & 21.33 & 7.33 & 4.67 & Membulat & Membulat & $\begin{array}{l}\text { Hijau } \\
\text { muda }\end{array}$ & Agak Kasar & Oblong & Rata & Menyirip \\
\hline BH-1 & 13,67 & 6,06 & 3,00 & Runcing & Membulat & Hijau & Halus & Ovate & Rata & Menyirip \\
\hline LG-1 & 15,00 & 6,02 & 4,00 & Meruncing & Membulat & $\begin{array}{l}\text { Hijau } \\
\text { tua }\end{array}$ & Agak Kasar & Elliptic & Rata & Menyirip \\
\hline KG-1 & 13.33 & 7.20 & 3.00 & Meruncing & Membulat & $\begin{array}{l}\text { Hijau } \\
\text { tua }\end{array}$ & Kasar & Elliptic & Rata & Menyirip \\
\hline KG-2 & 15,33 & 5,75 & 3,67 & Meruncing & Membulat & $\begin{array}{l}\text { Hijau } \\
\text { tua }\end{array}$ & Kasar & Elliptic & Rata & Menyirip \\
\hline KG-3 & 15,67 & 6,05 & 3,67 & Meruncing & Membulat & $\begin{array}{l}\text { Hijau } \\
\text { tua }\end{array}$ & Kasar & Elliptic & Rata & Menyirip \\
\hline KG-4 & 15,00 & 6,02 & 3,00 & Meruncing & Membulat & $\begin{array}{l}\text { Hijau } \\
\text { tua }\end{array}$ & Kasar & Elliptic & Rata & Menyirip \\
\hline KG-5 & 15,67 & 6,15 & 4,00 & Meruncing & Membulat & $\begin{array}{l}\text { Hijau } \\
\text { tua }\end{array}$ & Kasar & Elliptic & Rata & Menyirip \\
\hline KB-1 & 16.33 & 8.63 & 3.67 & Runcing & Membulat & Hijau & Kasar & Ovate & Rata & Menyirip \\
\hline $\begin{array}{c}5 \mathrm{KT}- \\
1\end{array}$ & 19.67 & 9.17 & 5.17 & Runcing & Membulat & $\begin{array}{l}\text { Hijau } \\
\text { tua }\end{array}$ & Kasar & Ovate & Rata & Menyirip \\
\hline
\end{tabular}




\begin{tabular}{|l|r|r|r|l|l|l|l|l|l|l|}
\hline SB-1 & 14.33 & 6.57 & 3.67 & Runcing & Berlekuk & $\begin{array}{l}\text { Hijau } \\
\text { tua }\end{array}$ & Kasar & Ovate & Rata & Menyirip \\
\hline ST-1 & 17.67 & 9.00 & 4.17 & Meruncing & Berlekuk & Hijau & Halus & Elliptic & Rata & Menyirip \\
\hline BS-1 & 17.67 & 8.00 & 4.33 & Meruncing & Berlekuk & $\begin{array}{l}\text { Hijau } \\
\text { tua }\end{array}$ & Kasar & Elliptic & Rata & Menyirip \\
\hline GN-1 & 16.33 & 6.83 & 4.33 & Runcing & Membulat & $\begin{array}{l}\text { Hijau } \\
\text { tua }\end{array}$ & Kasar & Ovate & Rata & Menyirip \\
\hline BA-1 & 16.00 & 7.57 & 5.00 & Meruncing & Membulat & Hijau & Halus & Elliptic & Rata & Menyirip \\
\hline
\end{tabular}


Lampiran 11. Data Morfologis Buah Tanaman Sijontiak di Kecamatan Guguak, Kabupaten Lima Puluh Kota

\begin{tabular}{|c|c|c|c|c|c|c|c|c|c|c|c|c|}
\hline $\begin{array}{l}\text { No } \\
\text { Ak } \\
\text { sesi }\end{array}$ & $\begin{array}{l}\text { Panjan } \\
\text { g } \\
\text { Tangka } \\
\text { i Utama } \\
\text { Buah }\end{array}$ & \begin{tabular}{|l|} 
Panjan \\
g \\
Tangka \\
i Buah
\end{tabular} & $\begin{array}{l}\text { Diam } \\
\text { eter } \\
\text { Buah }\end{array}$ & $\begin{array}{l}\text { Ketebalan } \\
\text { Daging }\end{array}$ & $\begin{array}{l}\text { Berat } \\
\text { Satu } \\
\text { Buah }\end{array}$ & $\begin{array}{l}\text { Jumlah } \\
\text { Buah } \\
\text { Per } \\
\text { Untaian }\end{array}$ & $\begin{array}{l}\text { Warna } \\
\text { Kulit } \\
\text { Buah }\end{array}$ & $\begin{array}{l}\text { Warna } \\
\text { Daging } \\
\text { Buah }\end{array}$ & $\begin{array}{l}\text { Rasa } \\
\text { Daging } \\
\text { Buah }\end{array}$ & $\begin{array}{l}\text { Bentuk } \\
\text { Buah }\end{array}$ & $\begin{array}{l}\text { Bentuk } \\
\text { Ujung } \\
\text { Buah }\end{array}$ & $\begin{array}{l}\text { Bentuk } \\
\text { Pangkal } \\
\text { Buah }\end{array}$ \\
\hline & \multicolumn{3}{|c|}{$\begin{array}{c}\text { Rata-Rata } \\
\text { (cm) }\end{array}$} & $\begin{array}{c}\text { Rata-Rata } \\
(\mathbf{m m})\end{array}$ & & $\begin{array}{l}\text { Rata- } \\
\text { rata } \\
\text { (Buah) }\end{array}$ & & & & & & \\
\hline $\begin{array}{l}\text { KT } \\
-1^{*}\end{array}$ & 14,33 & 1 & 1,93 & 2,3 & 4,58 & 6 & $\begin{array}{l}\text { Orange } \\
\text { kehita } \\
\mathrm{m} \\
\text { hitama } \\
\mathrm{n}\end{array}$ & $\begin{array}{l}\text { Orange } \\
\text { tua }\end{array}$ & $\begin{array}{l}\text { Manis } \\
\text { dengan } \\
\text { sedikit } \\
\text { asam }\end{array}$ & Globose & Convex & $\begin{array}{l}\text { Truncat } \\
\mathrm{e}\end{array}$ \\
\hline $\begin{array}{c}\text { KT } \\
-2\end{array}$ & 17,67 & 1,6 & 1,5 & 1,0 & 2,56 & 8 & $\begin{array}{l}\text { Hijau } \\
\text { tua }\end{array}$ & $\begin{array}{l}\text { Putih } \\
\text { susu }\end{array}$ & Asam & Globose & Convex & $\begin{array}{l}\text { Truncat } \\
\mathrm{e}\end{array}$ \\
\hline $\begin{array}{c}\text { KT } \\
-3\end{array}$ & 13,67 & 1,4 & 2.5 & 1,1 & 2,6 & 15 & $\begin{array}{l}\text { Hijau } \\
\text { muda }\end{array}$ & $\begin{array}{l}\text { Putih } \\
\text { susu }\end{array}$ & Asam & Oblate & $\begin{array}{l}\text { Truncat } \\
\mathrm{e}\end{array}$ & $\begin{array}{l}\text { Truncat } \\
\mathrm{e}\end{array}$ \\
\hline
\end{tabular}




\begin{tabular}{|c|c|c|c|c|c|c|c|c|c|c|c|c|}
\hline $\begin{array}{c}\text { PB- } \\
1 *\end{array}$ & 29,16 & 1,3 & 1,47 & 3,0 & 2.96 & 12 & $\begin{array}{l}\text { Orange } \\
\text { kehita } \\
\mathrm{m} \\
\text { hitama } \\
\mathrm{n}\end{array}$ & $\begin{array}{l}\text { Orange } \\
\text { muda }\end{array}$ & $\begin{array}{l}\text { Manis } \\
\text { dengan } \\
\text { sedikit } \\
\text { asam }\end{array}$ & Oval & Pointed & Convex \\
\hline $\begin{array}{l}\text { BT } \\
-1^{*}\end{array}$ & 20,17 & 1,53 & 2,23 & 2,3 & 3,36 & 6 & $\begin{array}{l}\text { Orange } \\
\text { tua }\end{array}$ & $\begin{array}{l}\text { Orange } \\
\text { tua }\end{array}$ & $\begin{array}{l}\text { Manis } \\
\text { dengan } \\
\text { sedikit } \\
\text { asam }\end{array}$ & Oblate & Convex & $\begin{array}{l}\text { Truncat } \\
\mathrm{e}\end{array}$ \\
\hline $\begin{array}{c}\text { BT } \\
-3\end{array}$ & 13,34 & 1,2 & 2.7 & 1,3 & 2,4 & 12 & $\begin{array}{l}\text { Hijau } \\
\text { muda }\end{array}$ & $\begin{array}{l}\text { Putih } \\
\text { susu }\end{array}$ & Asam & Oblate & $\begin{array}{l}\text { Truncat } \\
\mathrm{e}\end{array}$ & $\begin{array}{l}\text { Truncat } \\
\mathrm{e}\end{array}$ \\
\hline $\begin{array}{l}\text { KN } \\
-1^{*}\end{array}$ & 20,17 & 1,53 & 2,23 & 2,3 & 3,36 & 6 & $\begin{array}{l}\text { Orange } \\
\text { tua }\end{array}$ & $\begin{array}{l}\text { Orange } \\
\text { tua }\end{array}$ & $\begin{array}{l}\text { Manis } \\
\text { dengan } \\
\text { sedikit } \\
\text { asam }\end{array}$ & Oblate & $\begin{array}{l}\text { Truncat } \\
\mathrm{e}\end{array}$ & Convex \\
\hline $\begin{array}{c}\mathrm{KN} \\
-3\end{array}$ & 21,67 & 1 & 2,15 & 1,1 & 2,3 & 15 & $\begin{array}{l}\text { Hijau } \\
\text { tua }\end{array}$ & $\begin{array}{l}\text { Putih } \\
\text { susu }\end{array}$ & Asam & $\begin{array}{l}\text { Lain- } \\
\text { lain }\end{array}$ & $\begin{array}{l}\text { Mammif } \\
\text { orm }\end{array}$ & Convex \\
\hline $\begin{array}{c}\mathrm{KN} \\
-5\end{array}$ & 17,32 & 1,4 & 1,8 & 1,0 & 2,72 & 8 & $\begin{array}{l}\text { Hijau } \\
\text { tua }\end{array}$ & $\begin{array}{l}\text { Putih } \\
\text { susu }\end{array}$ & Asam & Globose & Convex & Convex \\
\hline $\begin{array}{l}\text { GK } \\
-1^{*}\end{array}$ & 23,8 & 1,7 & 2,43 & 2,7 & 3,28 & 7 & $\begin{array}{l}\text { Orange } \\
\text { tua }\end{array}$ & $\begin{array}{l}\text { Orange } \\
\text { tua }\end{array}$ & $\begin{array}{l}\text { Manis } \\
\text { dengan } \\
\text { sedikit }\end{array}$ & Oblate & Convex & $\begin{array}{l}\text { Truncat } \\
\mathrm{e}\end{array}$ \\
\hline
\end{tabular}




\begin{tabular}{|c|c|c|c|c|c|c|c|c|c|c|c|c|}
\hline & & & & & & & & & asam & & & \\
\hline $\begin{array}{l}\text { GK } \\
-2 *\end{array}$ & 17,5 & 1 & 2,16 & 2,5 & 4,4 & 7 & $\begin{array}{l}\text { Orange } \\
\text { tua }\end{array}$ & $\begin{array}{l}\text { Orange } \\
\text { muda }\end{array}$ & $\begin{array}{l}\text { Manis } \\
\text { dengan } \\
\text { sedikit } \\
\text { asam }\end{array}$ & $\begin{array}{l}\text { Lain- } \\
\text { lain }\end{array}$ & $\begin{array}{l}\text { Mammif } \\
\text { orm }\end{array}$ & Convex \\
\hline $\begin{array}{l}\text { GK } \\
-3 *\end{array}$ & 24 & 1,2 & 2,27 & 2,3 & 3,28 & 12 & $\begin{array}{l}\text { Orange } \\
\text { kehita } \\
\mathrm{m} \\
\text { hitama } \\
\mathrm{n}\end{array}$ & $\begin{array}{l}\text { Orange } \\
\text { tua }\end{array}$ & Manis & Globose & Convex & Convex \\
\hline $\begin{array}{l}\text { GK } \\
-4^{*}\end{array}$ & 24 & 1 & 2,1 & 3,0 & 3,12 & 17 & $\begin{array}{l}\text { Orange } \\
\text { tua }\end{array}$ & $\begin{array}{l}\text { Orange } \\
\text { tua }\end{array}$ & $\begin{array}{l}\text { Manis } \\
\text { dengan } \\
\text { sedikit } \\
\text { asam }\end{array}$ & $\begin{array}{l}\text { Lain- } \\
\text { Lain }\end{array}$ & $\begin{array}{l}\text { Mammif } \\
\text { orm }\end{array}$ & $\begin{array}{l}\text { Truncat } \\
\mathrm{e}\end{array}$ \\
\hline $\begin{array}{l}\text { GK } \\
-6\end{array}$ & 13,67 & 1 & 2,17 & 1,3 & 2,2 & 14 & $\begin{array}{l}\text { Hijau } \\
\text { muda }\end{array}$ & $\begin{array}{l}\text { Putih } \\
\text { susu }\end{array}$ & Asam & Oblate & $\begin{array}{l}\text { Truncat } \\
\mathrm{e}\end{array}$ & $\begin{array}{l}\text { Truncat } \\
\mathrm{e}\end{array}$ \\
\hline $\begin{array}{l}\text { TR } \\
-1 *\end{array}$ & 15,33 & 1 & 3 & 1,8 & 4,16 & 6 & $\begin{array}{l}\text { Orange } \\
\text { tua }\end{array}$ & $\begin{array}{l}\text { Orange } \\
\text { tua }\end{array}$ & $\begin{array}{l}\text { Manis } \\
\text { dengan } \\
\text { sedikit } \\
\text { asam }\end{array}$ & Oblate & $\begin{array}{l}\text { Truncat } \\
\text { e }\end{array}$ & $\begin{array}{l}\text { Truncat } \\
\mathrm{e}\end{array}$ \\
\hline $\begin{array}{l}\text { TR } \\
-2\end{array}$ & 19,67 & 1,3 & 2,4 & 1,2 & 2,5 & 16 & $\begin{array}{l}\text { Hijau } \\
\text { muda }\end{array}$ & $\begin{array}{l}\text { Putih } \\
\text { susu }\end{array}$ & Asam & $\begin{array}{l}\text { Lain- } \\
\text { lain }\end{array}$ & $\begin{array}{l}\text { Mammif } \\
\text { orm }\end{array}$ & $\begin{array}{l}\text { Truncat } \\
\mathrm{e}\end{array}$ \\
\hline
\end{tabular}




\begin{tabular}{|c|c|c|c|c|c|c|c|c|c|c|c|c|}
\hline $\begin{array}{l}\text { TR } \\
-3\end{array}$ & 16,33 & 1 & 2,2 & 1,3 & 2,1 & 8 & $\begin{array}{l}\text { Hijau } \\
\text { muda }\end{array}$ & $\begin{array}{l}\text { Putih } \\
\text { susu }\end{array}$ & Asam & Oblate & $\begin{array}{l}\text { Truncat } \\
\mathrm{e}\end{array}$ & Convex \\
\hline $\begin{array}{l}\mathrm{KI}- \\
1 *\end{array}$ & 21,33 & 1 & 2,67 & 2,5 & 2,9 & 6 & $\begin{array}{l}\text { Orange } \\
\text { tua }\end{array}$ & Orange & Manis & Oblate & $\begin{array}{l}\text { Truncat } \\
\mathrm{e}\end{array}$ & Convex \\
\hline $\begin{array}{c}\text { KI- } \\
2\end{array}$ & 21,67 & 1,4 & 2,3 & 1,2 & 2,13 & 16 & $\begin{array}{l}\text { Hijau } \\
\text { tua }\end{array}$ & $\begin{array}{l}\text { Putih } \\
\text { susu }\end{array}$ & Asam & $\begin{array}{l}\text { Lain- } \\
\text { lain }\end{array}$ & $\begin{array}{l}\text { Mammif } \\
\text { orm }\end{array}$ & Convex \\
\hline $\begin{array}{c}\text { KI- } \\
3\end{array}$ & 18 & 1,3 & 1,7 & 1,1 & 2,4 & 10 & $\begin{array}{l}\text { Hijau } \\
\text { muda }\end{array}$ & $\begin{array}{l}\text { Putih } \\
\text { susu }\end{array}$ & Asam & Oblate & $\begin{array}{l}\text { Truncat } \\
\mathrm{e}\end{array}$ & $\begin{array}{l}\text { Truncat } \\
\mathrm{e}\end{array}$ \\
\hline $\begin{array}{c}\text { KI- } \\
4\end{array}$ & 19 & 1,5 & 1,4 & 1,2 & 2,7 & 7 & $\begin{array}{l}\text { Hijau } \\
\text { muda }\end{array}$ & $\begin{array}{l}\text { Putih } \\
\text { susu }\end{array}$ & Asam & Oblate & $\begin{array}{l}\text { Truncat } \\
\mathrm{e}\end{array}$ & $\begin{array}{l}\text { Truncat } \\
\mathrm{e}\end{array}$ \\
\hline $\begin{array}{c}\text { KI- } \\
5\end{array}$ & 17 & 1,4 & 1,5 & 1,2 & 2,6 & 9 & $\begin{array}{l}\text { Hijau } \\
\text { muda }\end{array}$ & $\begin{array}{l}\text { Putih } \\
\text { susu }\end{array}$ & Asam & Oblate & $\begin{array}{l}\text { Truncat } \\
\mathrm{e}\end{array}$ & $\begin{array}{l}\text { Truncat } \\
\mathrm{e}\end{array}$ \\
\hline $\begin{array}{l}\text { TO } \\
-1 *\end{array}$ & 24 & 1 & 2,3 & 2,2 & 3,43 & 13 & $\begin{array}{l}\text { Orange } \\
\text { tua }\end{array}$ & $\begin{array}{l}\text { Orange } \\
\text { muda }\end{array}$ & $\begin{array}{l}\text { Manis } \\
\text { dengan } \\
\text { sedikit } \\
\text { asam }\end{array}$ & Oblate & Convex & $\begin{array}{l}\text { Truncat } \\
\mathrm{e}\end{array}$ \\
\hline $\begin{array}{l}\text { TO } \\
-2\end{array}$ & 21,3 & 1,3 & 1,8 & 2,0 & 2,13 & 15 & Hijau & $\begin{array}{l}\text { Putih } \\
\text { susu }\end{array}$ & Asam & $\begin{array}{l}\text { Lain- } \\
\text { lain }\end{array}$ & $\begin{array}{l}\text { Mammif } \\
\text { orm }\end{array}$ & $\begin{array}{l}\text { Truncat } \\
\mathrm{e}\end{array}$ \\
\hline
\end{tabular}




\begin{tabular}{|c|c|c|c|c|c|c|c|c|c|c|c|c|}
\hline $\begin{array}{l}\text { TJ- } \\
1 *\end{array}$ & 20,33 & 1,4 & 2,2 & 2,4 & 4,1 & 14 & Orange & $\begin{array}{l}\text { Orange } \\
\text { tua }\end{array}$ & $\begin{array}{l}\text { Manis } \\
\text { dengan } \\
\text { sedikit } \\
\text { asam }\end{array}$ & Globose & $\begin{array}{l}\text { Truncat } \\
\mathrm{e}\end{array}$ & Convex \\
\hline $\begin{array}{l}\text { TJ- } \\
2^{*}\end{array}$ & 21 & 1,4 & 2,2 & 2,3 & 4,2 & 14 & $\begin{array}{l}\text { Orange } \\
\text { muda }\end{array}$ & Orange & $\begin{array}{l}\text { Manis } \\
\text { dengan } \\
\text { sedikit } \\
\text { asam }\end{array}$ & Globose & $\begin{array}{l}\text { Truncat } \\
\mathrm{e}\end{array}$ & Convex \\
\hline $\begin{array}{l}\text { KK } \\
-1 *\end{array}$ & 18 & 1,5 & 2 & 2,4 & 3,23 & 7 & Orange & $\begin{array}{l}\text { Orange } \\
\text { tua }\end{array}$ & $\begin{array}{l}\text { Manis } \\
\text { dengan } \\
\text { sedikit } \\
\text { asam }\end{array}$ & Globose & $\begin{array}{l}\text { Truncat } \\
\mathrm{e}\end{array}$ & Convex \\
\hline $\begin{array}{l}\mathrm{AG} \\
-1^{*}\end{array}$ & 12 & 1 & 1,7 & 2,4 & 2,9 & 11 & $\begin{array}{l}\text { Orange } \\
\text { tua }\end{array}$ & $\begin{array}{l}\text { Orange } \\
\text { tua }\end{array}$ & $\begin{array}{l}\text { Manis } \\
\text { dengan } \\
\text { sedikit } \\
\text { asam }\end{array}$ & Oblate & $\begin{array}{l}\text { Truncat } \\
\mathrm{e}\end{array}$ & Convex \\
\hline $\begin{array}{c}A G \\
-2\end{array}$ & 16 & 1,3 & 1,8 & 1,1 & 2,4 & 8 & $\begin{array}{l}\text { Hijau } \\
\text { muda }\end{array}$ & $\begin{array}{l}\text { Putih } \\
\text { susu }\end{array}$ & asam & Oblate & $\begin{array}{l}\text { Truncat } \\
\mathrm{e}\end{array}$ & $\begin{array}{l}\text { Truncat } \\
\mathrm{e}\end{array}$ \\
\hline $\begin{array}{l}\text { PJ- } \\
1 *\end{array}$ & 21,3 & 1 & 2 & 2,2 & 4 & 14 & $\begin{array}{l}\text { Orange } \\
\text { muda }\end{array}$ & $\begin{array}{l}\text { Orange } \\
\text { tua }\end{array}$ & $\begin{array}{l}\text { Manis } \\
\text { dengan } \\
\text { sedikit } \\
\text { asam }\end{array}$ & Oblate & $\begin{array}{l}\text { Truncat } \\
\mathrm{e}\end{array}$ & $\begin{array}{l}\text { Truncat } \\
\mathrm{e}\end{array}$ \\
\hline
\end{tabular}




\begin{tabular}{|c|c|c|c|c|c|c|c|c|c|c|c|c|}
\hline $\begin{array}{c}\text { PK } \\
-1\end{array}$ & 15,67 & 1,3 & 2,2 & 1,1 & 3,5 & 14 & $\begin{array}{l}\text { Hijau } \\
\text { muda }\end{array}$ & $\begin{array}{l}\text { Putih } \\
\text { susu }\end{array}$ & Asam & Oblate & $\begin{array}{l}\text { Truncat } \\
\mathrm{e}\end{array}$ & $\begin{array}{l}\text { Truncat } \\
\mathrm{e}\end{array}$ \\
\hline $\begin{array}{c}\text { SI- } \\
1\end{array}$ & 22,3 & 1,3 & 2,4 & 1,2 & 2,2 & 15 & $\begin{array}{l}\text { Hijau } \\
\text { tua }\end{array}$ & $\begin{array}{l}\text { Putih } \\
\text { susu }\end{array}$ & Asam & $\begin{array}{l}\text { Lain- } \\
\text { lain }\end{array}$ & $\begin{array}{l}\text { Mammif } \\
\text { orm }\end{array}$ & Convex \\
\hline $\begin{array}{l}\text { BK } \\
-1 *\end{array}$ & 17,33 & 1,5 & 2,4 & 2,0 & 3,6 & 7 & $\begin{array}{l}\text { Orange } \\
\text { tua }\end{array}$ & $\begin{array}{l}\text { Orange } \\
\text { tua }\end{array}$ & $\begin{array}{l}\text { Manis } \\
\text { dengan } \\
\text { sedikit } \\
\text { asam }\end{array}$ & Oblate & $\begin{array}{l}\text { Truncat } \\
\mathrm{e}\end{array}$ & $\begin{array}{l}\text { Truncat } \\
\mathrm{e}\end{array}$ \\
\hline $\begin{array}{l}\text { BK } \\
-2 *\end{array}$ & 17,33 & 1,3 & 2,3 & 2,4 & 3,9 & 6 & $\begin{array}{l}\text { Orange } \\
\text { tua }\end{array}$ & $\begin{array}{l}\text { Orange } \\
\text { tua }\end{array}$ & $\begin{array}{l}\text { Manis } \\
\text { dengan } \\
\text { sedikit } \\
\text { asam }\end{array}$ & Oblate & $\begin{array}{l}\text { Truncat } \\
\mathrm{e}\end{array}$ & $\begin{array}{l}\text { Truncat } \\
\mathrm{e}\end{array}$ \\
\hline $\begin{array}{l}\text { BK } \\
-3^{*}\end{array}$ & 17 & 1,23 & 1,8 & 2,2 & 2.81 & 7 & $\begin{array}{l}\text { Orange } \\
\text { tua }\end{array}$ & Orange & $\begin{array}{l}\text { Manis } \\
\text { dengan } \\
\text { sedikit } \\
\text { asam }\end{array}$ & Globose & Convex & Convex \\
\hline $\begin{array}{c}\text { BH } \\
-1\end{array}$ & 23,6 & 1,3 & 2,5 & 2,4 & 2,4 & 16 & Hijau & $\begin{array}{l}\text { Putih } \\
\text { susu }\end{array}$ & Asam & $\begin{array}{l}\text { Lain- } \\
\text { lain }\end{array}$ & $\begin{array}{l}\text { Mammif } \\
\text { orm }\end{array}$ & Convex \\
\hline $\begin{array}{l}\text { KG } \\
-1 *\end{array}$ & 45,3 & 1,5 & 2,1 & 2,8 & 3,9 & 5 & $\begin{array}{l}\text { Orange } \\
\text { tua }\end{array}$ & Orange & $\begin{array}{l}\text { Manis } \\
\text { dengan } \\
\text { sedikit } \\
\text { asam }\end{array}$ & Globose & Convex & $\begin{array}{l}\text { Truncat } \\
\mathrm{e}\end{array}$ \\
\hline
\end{tabular}




\begin{tabular}{|c|c|c|c|c|c|c|c|c|c|c|c|c|}
\hline $\begin{array}{c}\text { KG } \\
-2\end{array}$ & 22 & 1,6 & 2,6 & 1,2 & 2,2 & 15 & $\begin{array}{l}\text { Hijau } \\
\text { tua }\end{array}$ & $\begin{array}{l}\text { Putih } \\
\text { susu }\end{array}$ & Asam & $\begin{array}{l}\text { Lain- } \\
\text { lain }\end{array}$ & $\begin{array}{l}\text { Mammif } \\
\text { orm }\end{array}$ & Convex \\
\hline $\begin{array}{c}\text { KG } \\
-3\end{array}$ & 24,33 & 1,4 & 2,7 & 1,3 & 2,4 & 16 & Hijau & $\begin{array}{l}\text { Putih } \\
\text { susu }\end{array}$ & Asam & $\begin{array}{l}\text { Lain- } \\
\text { lain }\end{array}$ & $\begin{array}{l}\text { Mammif } \\
\text { orm }\end{array}$ & Convex \\
\hline $\begin{array}{l}\text { KB } \\
-1 *\end{array}$ & 19 & 1,8 & 2,2 & 2,5 & 3,8 & 7 & $\begin{array}{l}\text { Orange } \\
\text { tua }\end{array}$ & $\begin{array}{l}\text { Orange } \\
\text { tua }\end{array}$ & $\begin{array}{l}\text { Manis } \\
\text { dengan } \\
\text { sedikit } \\
\text { asam }\end{array}$ & Globose & Convex & $\begin{array}{l}\text { Truncat } \\
\text { e }\end{array}$ \\
\hline $\begin{array}{c}5 \\
\text { KT } \\
-1 *\end{array}$ & 15,26 & 1,2 & 2,60 & 2,4 & 4,1 & 6 & $\begin{array}{l}\text { Orange } \\
\text { muda }\end{array}$ & $\begin{array}{l}\text { Orange } \\
\text { tua }\end{array}$ & $\begin{array}{l}\text { Manis } \\
\text { dengan } \\
\text { sedikit } \\
\text { asam }\end{array}$ & Oblate & $\begin{array}{l}\text { Truncat } \\
\mathrm{e}\end{array}$ & $\begin{array}{l}\text { Truncat } \\
\mathrm{e}\end{array}$ \\
\hline $\begin{array}{l}\text { SB- } \\
1 *\end{array}$ & 13,67 & 1,27 & 1,87 & 2,3 & 3,01 & 4 & Kuning & $\begin{array}{l}\text { Orange } \\
\text { tua }\end{array}$ & Asam & $\begin{array}{l}\text { Lain- } \\
\text { lain }\end{array}$ & $\begin{array}{l}\text { Mammif } \\
\text { orm }\end{array}$ & $\begin{array}{l}\text { Truncat } \\
\mathrm{e}\end{array}$ \\
\hline $\begin{array}{l}\text { ST- } \\
1^{*}\end{array}$ & 10 & 1 & 2,17 & 2,3 & 4,62 & 6 & $\begin{array}{l}\text { Orange } \\
\text { tua }\end{array}$ & Orange & $\begin{array}{l}\text { Manis } \\
\text { dengan } \\
\text { sedikit } \\
\text { asam }\end{array}$ & Globose & Convex & $\begin{array}{l}\text { Truncat } \\
\mathrm{e}\end{array}$ \\
\hline
\end{tabular}




\begin{tabular}{|c|c|c|c|c|c|c|c|c|c|c|c|c|}
\hline $\begin{array}{c}\text { BS- } \\
1 *\end{array}$ & 20,33 & 1,2 & 2,03 & 2,6 & 3,1 & 12 & $\begin{array}{l}\text { Orange } \\
\text { kehita } \\
\mathrm{m} \\
\text { hitama } \\
\mathrm{n}\end{array}$ & $\begin{array}{l}\text { Orange } \\
\text { tua }\end{array}$ & $\begin{array}{l}\text { Manis } \\
\text { dengan } \\
\text { sedikit } \\
\text { asam }\end{array}$ & Globose & Convex & Convex \\
\hline $\begin{array}{l}\text { GN } \\
-1 *\end{array}$ & 14,67 & 1 & 2,2 & 2,5 & 3,41 & 3 & Orange & $\begin{array}{l}\text { Orange } \\
\text { tua }\end{array}$ & $\begin{array}{l}\text { Manis } \\
\text { dengan } \\
\text { sedikit } \\
\text { asam }\end{array}$ & Globose & Convex & $\begin{array}{l}\text { Truncat } \\
\mathrm{e}\end{array}$ \\
\hline $\begin{array}{l}\text { BA } \\
-1 *\end{array}$ & 6,3 & 1 & 2,13 & 2,3 & 2.72 & 4 & $\begin{array}{l}\text { Orange } \\
\text { tua }\end{array}$ & $\begin{array}{l}\text { Orange } \\
\text { tua }\end{array}$ & $\begin{array}{l}\text { Manis } \\
\text { dengan } \\
\text { sedikit } \\
\text { asam }\end{array}$ & Oblate & $\begin{array}{l}\text { Truncat } \\
\text { e }\end{array}$ & $\begin{array}{l}\text { Truncat } \\
\mathrm{e}\end{array}$ \\
\hline
\end{tabular}

Keterangan: (*) aksesi yang buahnya masak 
Lampiran 12. Data Morfologis Biji Tanaman Sijontiak di Kecamatan Guguak, Kabupaten Lima Puluh Kota

\begin{tabular}{|l|l|l|l|l|l|l|}
\hline $\begin{array}{l}\text { No } \\
\text { Aksesi }\end{array}$ & $\begin{array}{l}\text { Panjang } \\
\text { Biji }\end{array}$ & $\begin{array}{l}\text { Lebar } \\
\text { Biji }\end{array}$ & $\begin{array}{l}\text { Berat } \\
\mathbf{1 0 0} \\
\text { Biji }\end{array}$ & $\begin{array}{l}\text { Jumlah Biji } \\
\text { per Buah }\end{array}$ & $\begin{array}{c}\text { Warna } \\
\text { Biji }\end{array}$ & Bentuk Biji \\
\hline & \multicolumn{2}{|c|}{ Rata-Rata } \\
$(\mathbf{m m})$ & $(\mathbf{g r})$ & $\begin{array}{l}\text { Rata-Rata } \\
\text { (bh) }\end{array}$ & & \\
\hline KT-1 & 9 & 8,3 & 8,1 & 3 & Putih & Ovoid \\
\hline PB-1 & 9,6 & 7,7 & 7,4 & 2 & Putih & Ovoid \\
\hline BT-1 & 9 & 8 & 5,7 & 2 & Putih & Ovoid \\
\hline KN-1 & 9,3 & 8,3 & 3,9 & 3 & Putih & Ovoid \\
\hline GK-1 & 9,7 & 8,7 & 5,9 & 3 & Putih & Ovoid \\
\hline GK-2 & 8,7 & 8,7 & 5,5 & 3 & Putih & Ovoid \\
\hline GK-3 & 7,3 & 7 & 5,5 & 4 & Putih & Ovoid \\
\hline GK-4 & 9,5 & 7,0 & 6,3 & 3 & Putih & Ovoid \\
\hline TR-1 & 9,3 & 9,3 & 5,8 & 2 & Putih & Ovoid \\
\hline KI-1 & 10 & 8,3 & 3,6 & 3 & Putih & Ovoid \\
\hline TO-1 & 9,7 & 8,3 & 6,5 & 2 & Putih & Ovoid \\
\hline TJ-1 & 9,7 & 7,33 & 5,4 & 3 & Putih & Ovoid \\
\hline TJ-2 & 10 & 8 & 6,6 & 3 & Putih & Ovoid \\
\hline KK-1 & 9,3 & 7,7 & 6,3 & 3 & Putih & Ovoid \\
\hline AG-1 & 9 & 7,3 & 6,3 & 3 & Putih & Ovoid \\
\hline PJ-1 & 9,7 & 8,33 & 5,5 & 3 & Putih & Ovoid \\
\hline BK-1 & 10 & 9,3 & 3,6 & 3 & Putih & Ovoid \\
\hline
\end{tabular}




\begin{tabular}{|l|l|l|l|l|l|l|}
\hline BK-2 & 10 & 9 & 7,2 & 2 & Putih & Ovoid \\
\hline BK-3 & 9,7 & 9,7 & 9 & 2 & Putih & Ovoid \\
\hline KG-1 & 9,7 & 8,7 & 7,5 & 3 & Putih & Ovoid \\
\hline KB-1 & 8 & 8 & 6,6 & 3 & Putih & Ovoid \\
\hline 5KT-1 & 9,3 & 9,0 & 6,0 & 3 & Putih & Ovoid \\
\hline SB-1 & 8,0 & 8,0 & 4,7 & 2 & Putih & Ovoid \\
\hline ST-1 & 10 & 9,5 & 6,3 & 3 & Putih & Ovoid \\
\hline BS-1 & 10 & 9,0 & 6,7 & 3 & Putih & Ovoid \\
\hline GN-1 & 10 & 7 & 4,7 & 3 & Putih & Ovoid \\
\hline BA-1 & 9,0 & 8,0 & 6 & 3 & Putih & Ovoid \\
\hline
\end{tabular}


Lampiran 13. Hasil Kuisioner dari pemilik tanaman sijontiak yang diamati di Kecamatan Guguak Kabupaten Lima Puluh Kota.

\begin{tabular}{|c|c|c|c|c|c|c|c|c|c|c|c|c|}
\hline $\begin{array}{l}\text { No } \\
\text { Aksesi }\end{array}$ & $\begin{array}{l}\text { Nama } \\
\text { Pemilik }\end{array}$ & Umur & Alamat & Pendidikan & $\begin{array}{l}\text { Alasan } \\
\text { Menanam }\end{array}$ & $\begin{array}{l}\text { Asal } \\
\text { Bibit }\end{array}$ & $\begin{array}{l}\text { Jumlah } \\
\text { Pohon }\end{array}$ & Pemeliharaan & Pemupukan & \multicolumn{2}{|c|}{$\begin{array}{l}\text { Pengendalian } \\
\text { HPT }\end{array}$} & $\begin{array}{l}\text { Cara } \\
\text { Panen }\end{array}$ \\
\hline & & & & & & & & & & Ada & Cara & \\
\hline KT-1 & Nisma & $\begin{array}{l}70 \\
\text { thn }\end{array}$ & Kubang & SD & Konsumsi & $\begin{array}{l}\text { Tidak } \\
\text { diketahui }\end{array}$ & $1 \mathrm{btg}$ & Tidak ada & Tidak ada & Tupai & $\begin{array}{l}\text { Tidak } \\
\text { ada }\end{array}$ & Memanjat \\
\hline KT-2 & Damai & $\begin{array}{l}55 \\
\text { thn }\end{array}$ & $\begin{array}{l}\text { Kubang } \\
\text { tungkek }\end{array}$ & SMP & Konsumsi & $\begin{array}{l}\text { Tidak } \\
\text { diketahui }\end{array}$ & $2 \mathrm{btg}$ & Tidak ada & Tidak ada & Tupai & $\begin{array}{l}\text { Tidak } \\
\text { ada }\end{array}$ & Memanjat \\
\hline KT-3 & Damai & $\begin{array}{l}55 \\
\text { thn }\end{array}$ & $\begin{array}{l}\text { Kubang } \\
\text { tungkek }\end{array}$ & SMP & Konsumsi & $\begin{array}{l}\text { Tidak } \\
\text { diketahui }\end{array}$ & $2 \mathrm{btg}$ & Tidak ada & Tidak ada & Tupai & $\begin{array}{l}\text { Tidak } \\
\text { ada }\end{array}$ & Memanjat \\
\hline PB-1 & Yasni, SH & $\begin{array}{l}50 \\
\text { thn }\end{array}$ & $\begin{array}{l}\text { Pincuran } \\
\text { batuang }\end{array}$ & Sarjana & Konsumsi & $\begin{array}{l}\text { Tidak } \\
\text { diketahui }\end{array}$ & $1 \mathrm{btg}$ & Tidak ada & Tidak ada & Tupai & $\begin{array}{l}\text { Tidak } \\
\text { ada }\end{array}$ & Memanjat \\
\hline PB-2 & Imral & $\begin{array}{l}65 \\
\text { thn }\end{array}$ & $\begin{array}{l}\text { Pincuran } \\
\text { batuang }\end{array}$ & SD & Konsumsi & $\begin{array}{l}\text { Daerah } \\
\text { setempat }\end{array}$ & $2 \mathrm{btg}$ & Tidak ada & Tidak ada & Tupai & $\begin{array}{l}\text { Tidak } \\
\text { ada }\end{array}$ & Memanjat \\
\hline PB-3 & Imral & $\begin{array}{l}65 \\
\text { thn }\end{array}$ & $\begin{array}{l}\text { Pincuran } \\
\text { batuang }\end{array}$ & SD & Konsumsi & $\begin{array}{l}\text { Daerah } \\
\text { setempat }\end{array}$ & $2 \mathrm{btg}$ & Tidak ada & Tidak ada & Tupai & $\begin{array}{l}\text { Tidak } \\
\text { ada }\end{array}$ & Memanjat \\
\hline BT-1 & Bakar & $\begin{array}{l}45 \\
\text { thn }\end{array}$ & $\begin{array}{l}\text { Balai } \\
\text { tolang }\end{array}$ & SMP & Konsumsi & $\begin{array}{l}\text { Tidak } \\
\text { diketahui }\end{array}$ & $1 \mathrm{btg}$ & Tidak ada & Tidak ada & Tupai & $\begin{array}{l}\text { Tidak } \\
\text { ada }\end{array}$ & Memanjat \\
\hline BT-2 & Rusmainar & 55 & Balai & SMA & Konsumsi & Tidak & $2 \mathrm{btg}$ & Tidak ada & Tidak ada & Tupai & Tidak & Memanjat \\
\hline
\end{tabular}




\begin{tabular}{|c|c|c|c|c|c|c|c|c|c|c|c|c|}
\hline & & thn & tolang & & & diketahui & & & & & ada & \\
\hline BT-3 & Rusmainar & $\begin{array}{l}55 \\
\text { thn }\end{array}$ & $\begin{array}{l}\text { Balai } \\
\text { tolang }\end{array}$ & SMA & Konsumsi & $\begin{array}{l}\text { Tidak } \\
\text { diketahui }\end{array}$ & $2 \mathrm{btg}$ & Tidak ada & Tidak ada & Tupai & $\begin{array}{l}\text { Tidak } \\
\text { ada }\end{array}$ & Memanjat \\
\hline $\mathrm{KN}-1$ & Mukhlis & $\begin{array}{l}66 \\
\text { thn }\end{array}$ & Katinggian & SD & Konsumsi & $\begin{array}{l}\text { Tidak } \\
\text { diketahui }\end{array}$ & $3 \mathrm{btg}$ & Tidak ada & Tidak ada & Tupai & $\begin{array}{l}\text { Tidak } \\
\text { ada }\end{array}$ & Memanjat \\
\hline $\mathrm{KN}-2$ & Mukhlis & $\begin{array}{l}66 \\
\text { thn }\end{array}$ & Katinggian & SD & Konsumsi & $\begin{array}{l}\text { Tidak } \\
\text { diketahui }\end{array}$ & $3 \mathrm{btg}$ & Tidak ada & Tidak ada & Tupai & $\begin{array}{l}\text { Tidak } \\
\text { ada }\end{array}$ & Memanjat \\
\hline $\mathrm{KN}-3$ & Mukhlis & $\begin{array}{l}66 \\
\text { thn }\end{array}$ & Katinggian & SD & Konsumsi & $\begin{array}{l}\text { Tidak } \\
\text { diketahui }\end{array}$ & $3 \mathrm{btg}$ & Tidak ada & Tidak ada & Tupai & $\begin{array}{l}\text { Tidak } \\
\text { ada }\end{array}$ & Memanjat \\
\hline $\mathrm{KN}-4$ & Rosma & $\begin{array}{l}60 \\
\text { thn }\end{array}$ & Katinggian & SMP & Konsumsi & $\begin{array}{l}\text { Tidak } \\
\text { diketahui }\end{array}$ & 2 btg & Tidak ada & Tidak ada & Tupai & $\begin{array}{l}\text { Tidak } \\
\text { ada }\end{array}$ & Memanjat \\
\hline $\mathrm{KN}-5$ & Rosma & $\begin{array}{l}60 \\
\text { thn }\end{array}$ & Katinggian & SMP & Konsumsi & $\begin{array}{l}\text { Tidak } \\
\text { diketahui }\end{array}$ & $2 \mathrm{btg}$ & Tidak ada & Tidak ada & Tupai & $\begin{array}{l}\text { Tidak } \\
\text { ada }\end{array}$ & Memanjat \\
\hline GK-1 & Anwar & $\begin{array}{l}32 \\
\text { thn }\end{array}$ & Guguak & $\begin{array}{l}\text { D3 } \\
\text { Politani }\end{array}$ & Konsumsi & $\begin{array}{l}\text { Tidak } \\
\text { diketahui }\end{array}$ & $1 \mathrm{btg}$ & Tidak ada & Tidak ada & Tupai & $\begin{array}{l}\text { Tidak } \\
\text { ada }\end{array}$ & Memanjat \\
\hline GK-2 & $\begin{array}{l}\text { Datuak Imi } \\
\text { Siamad }\end{array}$ & $\begin{array}{l}74 \\
\text { thn }\end{array}$ & Guguak & SMP & Konsumsi & $\begin{array}{l}\text { Tidak } \\
\text { diketahui }\end{array}$ & $2 \mathrm{btg}$ & Tidak ada & Tidak ada & Tupai & $\begin{array}{l}\text { Tidak } \\
\text { ada }\end{array}$ & Memanjat \\
\hline GK-3 & $\begin{array}{l}\text { Datuak Imi } \\
\text { Siamad }\end{array}$ & $\begin{array}{l}74 \\
\text { thn }\end{array}$ & Guguak & SMP & Konsumsi & $\begin{array}{l}\text { Tidak } \\
\text { diketahui }\end{array}$ & $2 \mathrm{btg}$ & Tidak ada & Tidak ada & Tupai & $\begin{array}{l}\text { Tidak } \\
\text { ada }\end{array}$ & Memanjat \\
\hline GK-4 & Can Datuak & $\begin{array}{l}60 \\
\text { thn }\end{array}$ & Guguak & SD & Konsumsi & $\begin{array}{l}\text { Tidak } \\
\text { diketahui }\end{array}$ & $3 \mathrm{btg}$ & Tidak ada & Tidak ada & Tupai & $\begin{array}{l}\text { Tidak } \\
\text { ada }\end{array}$ & Memanjat \\
\hline GK-5 & Can Datuak & 60 & Guguak & SD & Konsumsi & Tidak & $3 \mathrm{btg}$ & Tidak ada & Tidak ada & Tupai & Tidak & Memanjat \\
\hline
\end{tabular}




\begin{tabular}{|c|c|c|c|c|c|c|c|c|c|c|c|c|}
\hline & Kayo & thn & & & & diketahui & & & & & ada & \\
\hline GK-6 & $\begin{array}{l}\text { Can Datuak } \\
\text { Kayo }\end{array}$ & $\begin{array}{l}60 \\
\text { thn }\end{array}$ & Guguak & SD & Konsumsi & $\begin{array}{l}\text { Tidak } \\
\text { diketahui }\end{array}$ & $3 \mathrm{btg}$ & Tidak ada & Tidak ada & Tupai & $\begin{array}{l}\text { Tidak } \\
\text { ada }\end{array}$ & Memanjat \\
\hline TR-1 & Iyon & $\begin{array}{l}52 \\
\text { thn }\end{array}$ & Tiakar & Sma & Konsumsi & $\begin{array}{l}\text { Tidak } \\
\text { diketahui }\end{array}$ & $1 \mathrm{btg}$ & Tidak ada & Tidak ada & Tupai & $\begin{array}{l}\text { Tidak } \\
\text { ada }\end{array}$ & Memanjat \\
\hline TR-2 & Zainul Zuat & $\begin{array}{l}65 \\
\text { thn }\end{array}$ & $\begin{array}{l}\text { Tiakar } \\
\text { mudiak }\end{array}$ & SD & Konsumsi & $\begin{array}{l}\text { Tidak } \\
\text { diketahui }\end{array}$ & $2 \mathrm{btg}$ & Tidak ada & Tidak ada & Tupai & $\begin{array}{l}\text { Tidak } \\
\text { ada }\end{array}$ & Memanjat \\
\hline TR-3 & Dasmaidar & $\begin{array}{l}55 \\
\text { thn }\end{array}$ & $\begin{array}{l}\text { Tiakar } \\
\text { mudiak }\end{array}$ & SD & Konsumsi & $\begin{array}{l}\text { Tidak } \\
\text { diketahui }\end{array}$ & $2 \mathrm{btg}$ & Tidak ada & Tidak ada & Tupai & $\begin{array}{l}\text { Tidak } \\
\text { ada }\end{array}$ & Memanjat \\
\hline TR-4 & Zainul Zuat & $\begin{array}{l}65 \\
\text { thn }\end{array}$ & $\begin{array}{l}\text { Tiakar } \\
\text { mudiak }\end{array}$ & SD & Konsumsi & $\begin{array}{l}\text { Tidak } \\
\text { diketahui }\end{array}$ & $2 \mathrm{btg}$ & Tidak ada & Tidak ada & Tupai & $\begin{array}{l}\text { Tidak } \\
\text { ada }\end{array}$ & Memanjat \\
\hline TR-5 & Dasmaidar & $\begin{array}{l}55 \\
\text { thn }\end{array}$ & $\begin{array}{l}\text { Tiakar } \\
\text { mudiak }\end{array}$ & SD & Konsumsi & $\begin{array}{l}\text { Tidak } \\
\text { diketahui }\end{array}$ & $2 \mathrm{btg}$ & Tidak ada & Tidak ada & Tupai & $\begin{array}{l}\text { Tidak } \\
\text { ada }\end{array}$ & Memanjat \\
\hline KI-1 & Yulinar & $\begin{array}{l}69 \\
\text { thn }\end{array}$ & Kuranji & SMP & Konsumsi & $\begin{array}{l}\text { Tidak } \\
\text { diketahui }\end{array}$ & $1 \mathrm{btg}$ & Tidak ada & Tidak ada & Tupai & $\begin{array}{l}\text { Tidak } \\
\text { ada }\end{array}$ & Memanjat \\
\hline KI-2 & $\begin{array}{l}\text { Datuak } \\
\text { Rajo Adil }\end{array}$ & $\begin{array}{l}51 \\
\text { thn }\end{array}$ & Kuranji & S1 & Konsumsi & $\begin{array}{l}\text { Tidak } \\
\text { diketahui }\end{array}$ & $2 \mathrm{btg}$ & Tidak ada & Tidak ada & Tupai & $\begin{array}{l}\text { Tidak } \\
\text { ada }\end{array}$ & Memanjat \\
\hline KI-3 & $\begin{array}{l}\text { Datuak } \\
\text { Rajo Adil }\end{array}$ & $\begin{array}{l}51 \\
\text { thn }\end{array}$ & Kuranji & S1 & Konsumsi & $\begin{array}{l}\text { Tidak } \\
\text { diketahui }\end{array}$ & 2 btg & Tidak ada & Tidak ada & Tupai & $\begin{array}{l}\text { Tidak } \\
\text { ada }\end{array}$ & Memanjat \\
\hline KI-4 & Maliarti & $\begin{array}{l}64 \\
\text { thn }\end{array}$ & $\begin{array}{l}\text { Kuranji } \\
\text { tangah }\end{array}$ & SMP & Konsumsi & $\begin{array}{l}\text { Tidak } \\
\text { diketahui }\end{array}$ & $\begin{array}{l}2 \mathrm{btg} \\
\mathrm{btg}\end{array}$ & Tidak ada & Tidak ada & Tupai & $\begin{array}{l}\text { Tidak } \\
\text { ada }\end{array}$ & Memanjat \\
\hline KI-5 & Maliarti & 64 & Kuranji & SMP & Konsumsi & Tidak & 2 btg & Tidak ada & Tidak ada & Tupai & Tidak & Memanjat \\
\hline
\end{tabular}




\begin{tabular}{|c|c|c|c|c|c|c|c|c|c|c|c|c|}
\hline & & thn & tangah & & & diketahui & btg & & & & ada & \\
\hline KI-6 & Hj. Nurlela & $\begin{array}{l}80 \\
\text { thn }\end{array}$ & Kuranji & SMA & Konsumsi & $\begin{array}{l}\text { Tidak } \\
\text { diketahui }\end{array}$ & $3 \mathrm{btg}$ & Tidak ada & Tidak ada & Tupai & $\begin{array}{l}\text { Tidak } \\
\text { ada }\end{array}$ & Memanjat \\
\hline KI-7 & Hj. Nurlela & $\begin{array}{l}80 \\
\text { thn }\end{array}$ & Kuranji & SMA & Konsumsi & \begin{tabular}{|l|} 
Tidak \\
diketahui
\end{tabular} & $3 \mathrm{btg}$ & Tidak ada & Tidak ada & Tupai & $\begin{array}{l}\text { Tidak } \\
\text { ada }\end{array}$ & Memanjat \\
\hline KI-8 & Hj. Nurlela & $\begin{array}{l}80 \\
\text { thn }\end{array}$ & Kuranji & SMA & Konsumsi & $\begin{array}{l}\text { Tidak } \\
\text { diketahui }\end{array}$ & $3 \mathrm{btg}$ & Tidak ada & Tidak ada & Tupai & $\begin{array}{l}\text { Tidak } \\
\text { ada }\end{array}$ & Memanjat \\
\hline KI-9 & Ujang & $\begin{array}{l}55 \\
\text { thn }\end{array}$ & Kuranji & SMP & Konsumsi & $\begin{array}{l}\text { Tidak } \\
\text { diketahui }\end{array}$ & $2 \mathrm{btg}$ & Tidak ada & Tidak ada & Tupai & $\begin{array}{l}\text { Tidak } \\
\text { ada }\end{array}$ & Memanjat \\
\hline KI-10 & Ujang & $\begin{array}{l}55 \\
\text { thn }\end{array}$ & Kuranji & SMP & Konsumsi & $\begin{array}{l}\text { Tidak } \\
\text { diketahui }\end{array}$ & $2 \mathrm{btg}$ & Tidak ada & Tidak ada & Tupai & $\begin{array}{l}\text { Tidak } \\
\text { ada }\end{array}$ & Memanjat \\
\hline TO-1 & Hj.Rosnita & $\begin{array}{l}54 \\
\text { thn }\end{array}$ & $\begin{array}{l}7 \text { Koto } \\
\text { talago }\end{array}$ & SMA & Konsumsi & $\begin{array}{l}\text { Tidak } \\
\text { diketahui }\end{array}$ & $2 \mathrm{btg}$ & Tidak ada & Tidak ada & Tupai & $\begin{array}{l}\text { Tidak } \\
\text { ada }\end{array}$ & Memanjat \\
\hline TO-2 & Hj.Rosnita & $\begin{array}{l}54 \\
\text { thn }\end{array}$ & $\begin{array}{l}7 \text { Koto } \\
\text { talago }\end{array}$ & SMA & Konsumsi & \begin{tabular}{|l|} 
Tidak \\
diketahui
\end{tabular} & $2 \mathrm{btg}$ & Tidak ada & Tidak ada & Tupai & $\begin{array}{l}\text { Tidak } \\
\text { ada }\end{array}$ & Memanjat \\
\hline TJ-1 & Erna Yulia & $\begin{array}{l}52 \\
\text { thn }\end{array}$ & $\begin{array}{l}\text { Tanjung } \\
\text { jati }\end{array}$ & SD & Konsumsi & $\begin{array}{l}\text { Tidak } \\
\text { diketahui }\end{array}$ & $2 \mathrm{btg}$ & Tidak ada & Tidak ada & Tupai & $\begin{array}{l}\text { Tidak } \\
\text { ada }\end{array}$ & Memanjat \\
\hline TJ-2 & Erna Yulia & $\begin{array}{l}52 \\
\text { thn }\end{array}$ & $\begin{array}{l}\text { Tanjung } \\
\text { jati }\end{array}$ & SD & Konsumsi & \begin{tabular}{|l|} 
Tidak \\
diketahui
\end{tabular} & $2 \mathrm{btg}$ & Tidak ada & Tidak ada & Tupai & $\begin{array}{l}\text { Tidak } \\
\text { ada }\end{array}$ & Memanjat \\
\hline KK-1 & Kasmiati & $\begin{array}{l}60 \\
\text { thn }\end{array}$ & $\begin{array}{l}\text { Koto } \\
\text { kociak }\end{array}$ & SMA & Konsumsi & $\begin{array}{l}\text { Tidak } \\
\text { diketahui }\end{array}$ & $2 \mathrm{btg}$ & Tidak ada & Tidak ada & Tupai & $\begin{array}{l}\text { Tidak } \\
\text { ada }\end{array}$ & Memanjat \\
\hline KK-2 & Kasmiati & 60 & Koto & SMA & Konsumsi & Tidak & $2 \mathrm{btg}$ & Tidak ada & Tidak ada & Tupai & Tidak & Memanjat \\
\hline
\end{tabular}




\begin{tabular}{|c|c|c|c|c|c|c|c|c|c|c|c|c|}
\hline & & thn & kociak & & & diketahui & & & & & ada & \\
\hline AG-1 & Rosni & $\begin{array}{l}60 \\
\text { thn }\end{array}$ & $\begin{array}{l}\text { Ampang } \\
\text { godang }\end{array}$ & $\mathrm{SD}$ & Konsumsi & $\begin{array}{l}\text { Tidak } \\
\text { diketahui }\end{array}$ & $2 \mathrm{btg}$ & Tidak ada & Tidak ada & Tupai & $\begin{array}{l}\text { Tidak } \\
\text { ada }\end{array}$ & Memanjat \\
\hline AG-2 & Rosni & $\begin{array}{l}60 \\
\text { thn }\end{array}$ & $\begin{array}{l}\text { Ampang } \\
\text { godang }\end{array}$ & SD & Konsumsi & $\begin{array}{l}\text { Tidak } \\
\text { diketahui }\end{array}$ & $2 \mathrm{btg}$ & Tidak ada & Tidak ada & Tupai & $\begin{array}{l}\text { Tidak } \\
\text { ada }\end{array}$ & Memanjat \\
\hline PK-1 & Rudi & $\begin{array}{l}55 \\
\text { thn }\end{array}$ & $\begin{array}{l}\text { Padang } \\
\text { kandih }\end{array}$ & SMP & Konsumsi & $\begin{array}{l}\text { Tidak } \\
\text { diketahui }\end{array}$ & $1 \mathrm{btg}$ & Tidak ada & Tidak ada & Tupai & $\begin{array}{l}\text { Tidak } \\
\text { ada }\end{array}$ & Memanjat \\
\hline SI-1 & Zulfandi & $\begin{array}{l}59 \\
\text { thn }\end{array}$ & Sipingai & SD & Konsumsi & $\begin{array}{l}\text { Tidak } \\
\text { diketahui }\end{array}$ & $1 \mathrm{btg}$ & Tidak ada & Tidak ada & Tupai & $\begin{array}{l}\text { Tidak } \\
\text { ada }\end{array}$ & Memanjat \\
\hline PJ-1 & Zamri & $\begin{array}{l}65 \\
\text { thn }\end{array}$ & $\begin{array}{l}\text { Padang } \\
\text { jopang }\end{array}$ & SD & Konsumsi & $\begin{array}{l}\text { Tidak } \\
\text { diketahui }\end{array}$ & $1 \mathrm{btg}$ & Tidak ada & Tidak ada & Tupai & $\begin{array}{l}\text { Tidak } \\
\text { ada }\end{array}$ & Memanjat \\
\hline BK-1 & Welfrida & $\begin{array}{l}38 \\
\text { thn }\end{array}$ & Balik & SD & Konsumsi & $\begin{array}{l}\text { Tidak } \\
\text { diketahui }\end{array}$ & $3 \mathrm{btg}$ & Tidak ada & Tidak ada & Tupai & $\begin{array}{l}\text { Tidak } \\
\text { ada }\end{array}$ & Memanjat \\
\hline BK-2 & Welfrida & $\begin{array}{l}38 \\
\text { thn }\end{array}$ & Balik & SD & Konsumsi & \begin{tabular}{|l|} 
Tidak \\
diketahui
\end{tabular} & $3 \mathrm{btg}$ & Tidak ada & Tidak ada & Tupai & $\begin{array}{l}\text { Tidak } \\
\text { ada }\end{array}$ & Memanjat \\
\hline BK-3 & Welfrida & $\begin{array}{l}38 \\
\text { thn }\end{array}$ & Balik & SD & Konsumsi & $\begin{array}{l}\text { Tidak } \\
\text { diketahui }\end{array}$ & $3 \mathrm{btg}$ & Tidak ada & Tidak ada & Tupai & $\begin{array}{l}\text { Tidak } \\
\text { ada }\end{array}$ & Memanjat \\
\hline BH-1 & Zurmiati & $\begin{array}{l}62 \\
\text { thn }\end{array}$ & Boncah & SMP & Konsumsi & \begin{tabular}{|l|} 
Tidak \\
diketahui
\end{tabular} & $3 \mathrm{btg}$ & Tidak ada & Tidak ada & Tupai & $\begin{array}{l}\text { Tidak } \\
\text { ada }\end{array}$ & Memanjat \\
\hline LG-1 & Nurhayati & $\begin{array}{l}58 \\
\text { thn }\end{array}$ & Lokung & SMA & Konsumsi & $\begin{array}{l}\text { Tidak } \\
\text { diketahui }\end{array}$ & $3 \mathrm{btg}$ & Tidak ada & Tidak ada & Tupai & $\begin{array}{l}\text { Tidak } \\
\text { ada }\end{array}$ & Memanjat \\
\hline KG-1 & Syamsirman & 64 & Kubang & STM & Konsumsi & Tidak & $3 \mathrm{btg}$ & Tidak ada & Tidak ada & Tupai & Tidak & Memanjat \\
\hline
\end{tabular}




\begin{tabular}{|c|c|c|c|c|c|c|c|c|c|c|c|c|}
\hline & & thn & & & & diketahui & & & & & ada & \\
\hline KG-2 & Syamsirman & $\begin{array}{l}64 \\
\text { thn }\end{array}$ & Kubang & STM & Konsumsi & $\begin{array}{l}\text { Tidak } \\
\text { diketahui }\end{array}$ & $2 \mathrm{btg}$ & Tidak ada & Tidak ada & Tupai & $\begin{array}{l}\text { Tidak } \\
\text { ada }\end{array}$ & Memanjat \\
\hline KG-3 & Syamsirman & $\begin{array}{l}64 \\
\text { thn }\end{array}$ & Kubang & STM & Konsumsi & $\begin{array}{l}\text { Tidak } \\
\text { diketahui }\end{array}$ & $2 \mathrm{btg}$ & Tidak ada & Tidak ada & Tupai & $\begin{array}{l}\text { Tidak } \\
\text { ada }\end{array}$ & Memanjat \\
\hline KG-4 & Hasnah & $\begin{array}{l}58 \\
\text { thn }\end{array}$ & Kubang & SMP & Konsumsi & $\begin{array}{l}\text { Tidak } \\
\text { diketahui }\end{array}$ & $2 \mathrm{btg}$ & Tidak ada & Tidak ada & Tupai & $\begin{array}{l}\text { Tidak } \\
\text { ada }\end{array}$ & Memanjat \\
\hline KG-5 & Hasnah & $\begin{array}{l}58 \\
\text { thn }\end{array}$ & Kubang & SMP & Konsumsi & $\begin{array}{l}\text { Tidak } \\
\text { diketahui }\end{array}$ & $2 \mathrm{btg}$ & Tidak ada & Tidak ada & Tupai & $\begin{array}{l}\text { Tidak } \\
\text { ada }\end{array}$ & Memanjat \\
\hline KB-1 & Hasna & $\begin{array}{l}80 \\
\text { thn }\end{array}$ & Koto baru & SMP & Konsumsi & $\begin{array}{l}\text { Tidak } \\
\text { diketahui }\end{array}$ & $1 \mathrm{btg}$ & Tidak ada & Tidak ada & Tupai & $\begin{array}{l}\text { Tidak } \\
\text { ada }\end{array}$ & Memanjat \\
\hline $5 \mathrm{KT}-1$ & Zulmetra & $\begin{array}{l}42 \\
\text { thn }\end{array}$ & Limo koto & SMA & Konsumsi & $\begin{array}{l}\text { Tidak } \\
\text { diketahui }\end{array}$ & $1 \mathrm{btg}$ & Tidak ada & Tidak ada & Tupai & $\begin{array}{l}\text { Tidak } \\
\text { ada }\end{array}$ & Memanjat \\
\hline SB-1 & $\begin{array}{l}\text { Yeni } \\
\text { Gusmarni }\end{array}$ & $\begin{array}{l}47 \\
\text { thn }\end{array}$ & $\begin{array}{l}\text { Siamang } \\
\text { bunyi }\end{array}$ & SMA & Konsumsi & \begin{tabular}{|l|} 
Tidak \\
diketahui
\end{tabular} & $1 \mathrm{btg}$ & Tidak ada & Tidak ada & Tupai & $\begin{array}{l}\text { Tidak } \\
\text { ada }\end{array}$ & Memanjat \\
\hline ST-1 & Ramiandi & $\begin{array}{l}46 \\
\text { thn }\end{array}$ & $\begin{array}{l}\text { Sungai } \\
\text { tolang }\end{array}$ & SMA & Konsumsi & $\begin{array}{l}\text { Tidak } \\
\text { diketahui }\end{array}$ & $1 \mathrm{btg}$ & Tidak ada & Tidak ada & Tupai & $\begin{array}{l}\text { Tidak } \\
\text { ada }\end{array}$ & Memanjat \\
\hline BS-1 & Erna & $\begin{array}{l}55 \\
\text { thn }\end{array}$ & Belubus & SD & Konsumsi & \begin{tabular}{|l|} 
Tidak \\
diketahui
\end{tabular} & $1 \mathrm{btg}$ & Tidak ada & Tidak ada & Tupai & $\begin{array}{l}\text { Tidak } \\
\text { ada }\end{array}$ & Memanjat \\
\hline GN-1 & Niar & $\begin{array}{l}80 \\
\text { thn }\end{array}$ & $\begin{array}{l}\text { Guguak } \\
\text { nunang }\end{array}$ & SD & Konsumsi & $\begin{array}{l}\text { Tidak } \\
\text { diketahui }\end{array}$ & $1 \mathrm{btg}$ & Tidak ada & Tidak ada & Tupai & $\begin{array}{l}\text { Tidak } \\
\text { ada }\end{array}$ & Memanjat \\
\hline BA-1 & Mena & 65 & Bukit apit & SD & Konsumsi & Tidak & $1 \mathrm{btg}$ & Tidak ada & Tidak ada & Tupai & Tidak & Memanjat \\
\hline
\end{tabular}




\begin{tabular}{|l|l|l|l|l|l|l|l|l|l|l|l|}
\hline & thn & & & & diketahui & & & & & & \\
\hline
\end{tabular}


Lampiran 14. Data analisa kadar gula sijontiak dengan alat hand refraktometer

\begin{tabular}{|c|c|c|c|c|}
\hline \multirow{2}{*}{ kode } & \multicolumn{2}{|c|}{$\%$ brix } & \multirow{2}{*}{ Rata-Rata (\%) } & \multirow{2}{*}{ Keterangan } \\
\hline & 1 & 2 & & \\
\hline $\mathrm{KT}-1$ & 23 & 24 & 23.5 & Sangat Manis \\
\hline PB-1 & 20 & 21 & 20.5 & Sangat Manis \\
\hline BT-1 & 19 & 21 & 20 & Manis \\
\hline $\mathrm{KN}-1$ & 24 & 24 & 24 & Sangat Manis \\
\hline GK-1 & 19 & 19 & 19 & Manis \\
\hline GK-2 & 18 & 18 & 18 & Manis \\
\hline GK-3 & 20.5 & 23 & 21.75 & Sangat Manis \\
\hline GK-4 & 19.5 & 21 & 20.25 & Manis \\
\hline TR-1 & 24 & 22 & 23 & Sangat Manis \\
\hline KI-1 & 18 & 15 & 16.5 & Manis \\
\hline TO-1 & 23 & 19 & 21 & Sangat Manis \\
\hline TJ-1 & 24 & 24.5 & 24.25 & Sangat Manis \\
\hline TJ-2 & 20 & 20 & 20 & Manis \\
\hline KK-1 & 22 & 20 & 21 & Sangat Manis \\
\hline AG-1 & 23 & 24 & 23.5 & Sangat Manis \\
\hline PJ-1 & 17.5 & 18 & 17.75 & Manis \\
\hline BK-1 & 21 & 22 & 21.5 & Sangat Manis \\
\hline BK-2 & 24 & 21 & 22.5 & Sangat Manis \\
\hline BK-3 & 24 & 23 & 23.5 & Sangat Manis \\
\hline KG-1 & 23 & 23 & 23 & Sangat Manis \\
\hline KB-1 & 24 & 23 & 23.5 & Sangat Manis \\
\hline $5 \mathrm{KT}-1$ & 23 & 25 & 24 & Sangat Manis \\
\hline SB-1 & 17.5 & 22 & 19.75 & Manis \\
\hline ST-1 & 20 & 22 & 21 & Sangat Manis \\
\hline BS-1 & 19 & 19.5 & 19.25 & Manis \\
\hline GN-1 & 19 & 20 & 19.5 & Manis \\
\hline BA-1 & 20 & 20 & 20 & Manis \\
\hline
\end{tabular}

Ket: $<10 \%=$ Asam

$10-15 \%=$ Agak Manis

$16-20 \%=$ Manis

$>20 \%=$ Sangat Manis

Sumber: Laboratorium Tekhnologi Hasil Pertanian UNAND 
Lampiran 15. Keterangan mengenai kode aksesi pada tanaman sijontiak

\begin{tabular}{|c|c|c|}
\hline No & Kode Aksesi & Keterangan \\
\hline 1 & KT-1 & Kubang Tungkek-1 \\
\hline 2 & KT-2 & Kubang Tungkek-2 \\
\hline 3 & KT-3 & Kubang Tungkek-3 \\
\hline 4 & PB-1 & Pincuran Botuang-1 \\
\hline 5 & PB-2 & Pincuran Botuang-2 \\
\hline 6 & PB-3 & Pincuran Botuang-3 \\
\hline 7 & BT-1 & Balai Tolang-1 \\
\hline 8 & BT-2 & Balai Tolang-2 \\
\hline 9 & BT-3 & Balai Tolang-3 \\
\hline 10 & KN-1 & Katinggian-1 \\
\hline 11 & KN-2 & Katinggian-2 \\
\hline 12 & KN-3 & Katinggian-3 \\
\hline 13 & $\mathrm{KN}-4$ & Katinggian-4 \\
\hline 14 & KN-5 & Katinggian-5 \\
\hline 15 & GK-1 & Guguak-1 \\
\hline 16 & GK-2 & Guguak-2 \\
\hline 17 & GK-3 & Guguak-3 \\
\hline 18 & GK-4 & Guguak-4 \\
\hline 19 & GK-5 & Guguak-5 \\
\hline 20 & GK-6 & Guguak-6 \\
\hline 21 & TR-1 & Tiakar-1 \\
\hline 22 & TR-2 & Tiakar-2 \\
\hline 23 & TR-3 & Tiakar-3 \\
\hline
\end{tabular}




\begin{tabular}{|c|c|c|}
\hline 24 & TR-4 & Tiakar-4 \\
\hline 25 & TR-5 & Tiakar-5 \\
\hline 26 & KI-1 & Kuranji-1 \\
\hline 27 & KI-2 & Kuranji-2 \\
\hline 28 & KI-3 & Kuranji-3 \\
\hline 29 & KI-4 & Kuranji-4 \\
\hline 30 & KI-5 & Kuranji-5 \\
\hline 31 & KI-6 & Kuranji-6 \\
\hline 32 & KI-7 & Kuranji-7 \\
\hline 33 & KI-8 & Kuranji-8 \\
\hline 34 & KI-9 & Kuranji-9 \\
\hline 35 & KI-10 & Kuranji-10 \\
\hline 36 & TO-1 & Talago-11 \\
\hline 37 & TO-2 & Talago-12 \\
\hline 38 & TJ-1 & Tanjuang Jati-1 \\
\hline 39 & TJ-2 & Tanjuang Jati-2 \\
\hline 40 & KK-1 & Koto Kociak-1 \\
\hline 41 & KK-2 & Koto Kociak-2 \\
\hline 42 & AG-1 & Ampang Godang-1 \\
\hline 43 & AG-2 & Ampang Godang-2 \\
\hline 44 & PJ-1 & Padang Jopang-1 \\
\hline 45 & PK-1 & Padang Kandih-1 \\
\hline 46 & SI-1 & Sipingai-1 \\
\hline 47 & BK-1 & Balik-1 \\
\hline 48 & BK-2 & Balik-2 \\
\hline
\end{tabular}




\begin{tabular}{|c|c|c|}
\hline 49 & BK-3 & Balik-3 \\
\hline 50 & BH-1 & Boncah-1 \\
\hline 51 & LG-1 & Lokung-1 \\
\hline 52 & KG-1 & Kubang-1 \\
\hline 53 & KG-2 & Kubang-2 \\
\hline 54 & KG-3 & Kubang-3 \\
\hline 55 & KG-4 & Kubang-4 \\
\hline 56 & KG-5 & Kubang-5 \\
\hline 57 & KB-1 & Koto Baru-1 \\
\hline 58 & 5KT-1 & Limo Koto-1 \\
\hline 59 & SB-1 & Siamang Bunyi-1 \\
\hline 60 & ST-1 & Sungai Tolang-1 \\
\hline 61 & BS-1 & Belubus-1 \\
\hline 62 & GN-1 & Guguak Nunang-1 \\
\hline 63 & BA-1 & Bukit Apit-1 \\
\hline
\end{tabular}


Lampiran 16. Deskripsi 63 aksesi tanaman sijontiak yang diamati di Kabupaten Lima Puluh Kota

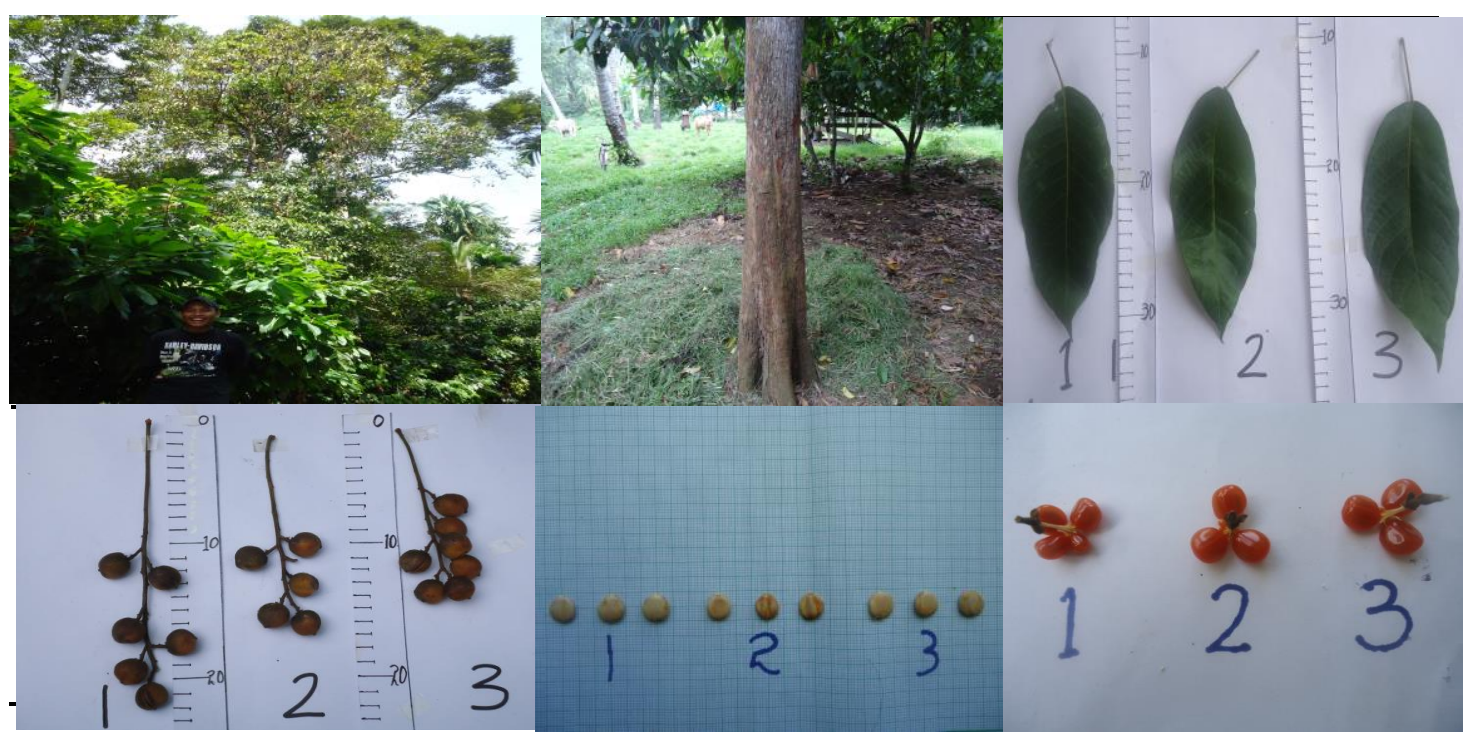

No Aksesi

Asal daerah

Guguak

Titik koordinat

Ketinggian tempat

Tinggi tanaman

Bentuk tajuk

Bentuk batang

- Warna batang

- Diameter batang

- Permukaan batang

Bentuk daun

- Permukaan daun

- Panjang daun

- Lebar daun

- Warna daun

Bentuk buah

- Ujung buah

- Pangkal buah

- Warna buah

- Diamater buah

Bentuk Biji
: KT-1

: Jorong Kubang Tungkek, Kecamatan

: LS: $00^{\circ} 08^{\prime} 10.0^{\prime \prime}$ dan BT: $100^{0} 32^{\prime} 32.8^{\prime \prime}$

: $533 \mathrm{~m} \mathrm{dpl}$

: $20,65 \mathrm{~m}$

: Spherical

: Bulat

: Coklat

: $99 \mathrm{~cm}$

: Agak kasar

:Ovate

:Halus

$: 19 \mathrm{~cm}$

$: 7,5 \mathrm{~cm}$

: Hijau

: Globose

: Convex

: Truncate

: Orange kehitam hitaman

: $1,93 \mathrm{~cm}$

: Ovoid 